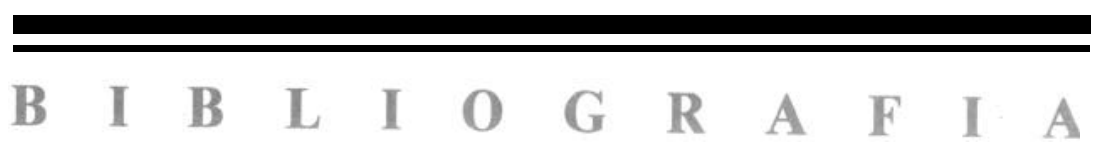




\section{LA FILOSOFÍA DEL DERECHO EN ESPAÑA (1985)}

Esta sección ha sido coordinada por Josep Aguiló Regla y Francisco López Ruiz. Las iniciales que aparecen al final de cada ficha (cuando el resumen no ha sido confeccionado por el propio autor) corresponden a los siguientes nombres: Josep Aguiló Regla, Manuel Atienza, Adela Aura Larios, Manuel Avilés Gomez, Emilio Cencerrado Millán, Antonio Doval Pais, Rafael Durán Ferrández, Carmelo Gómez Torres, Daniel González Lagier, Luis Aurelio González Prieto, Rafael González-Tablas, Francisco López Ruiz. Santiago Martínez Atienza, María José Masiá Canuto, Antonio José Muñoz Victoria y Antonio Ruiz de la Cuesta. 


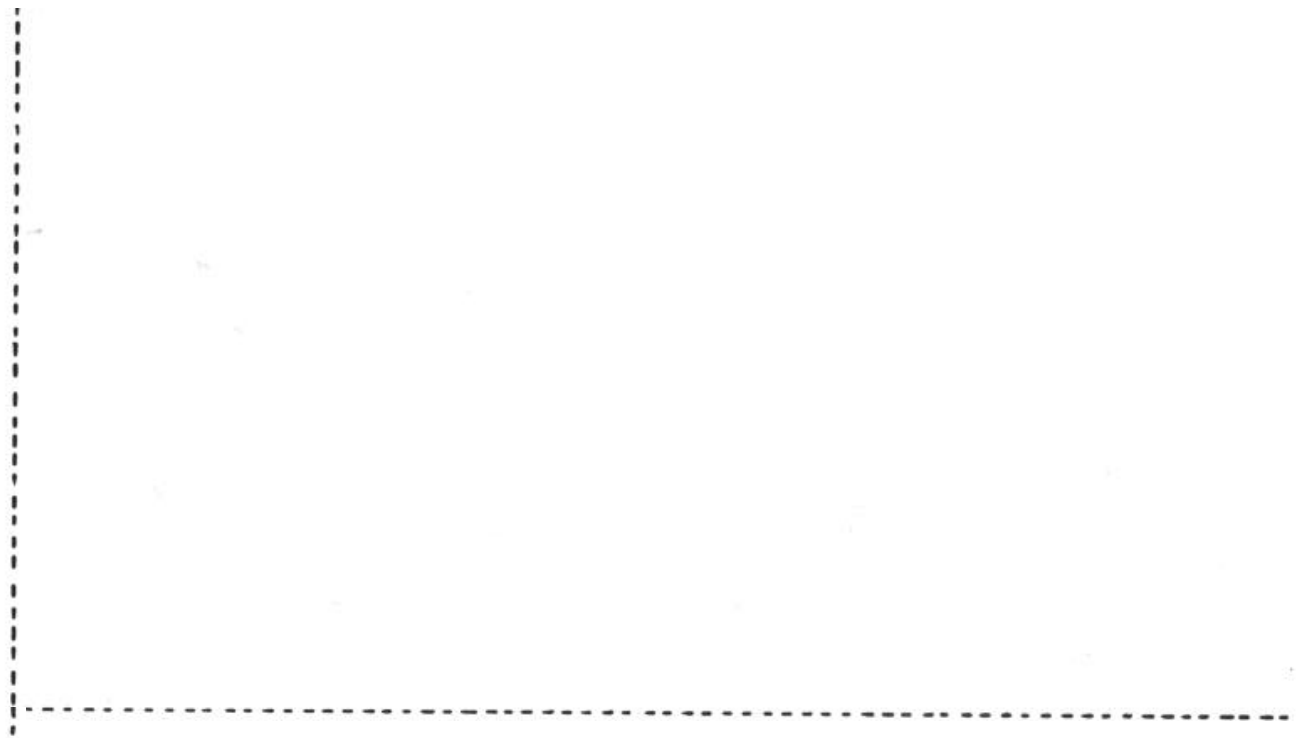

\section{AGRA ROMERO, M. ${ }^{a}$ José.}

\section{J. Rawls: el sentido de la justicia en una sociedad democrática.}

Ed. Universidad de Santiago, Santiago de Compostela, 1985, 175 págs.

Este libro, como expresa su subtítulo «El sentido de la justicia en una sociedad democrática», trata no sólo de describir la teoría de la justicia de Rawls, sino tambien de desvelar una serie de claves que subyacen en su obra: antropológicas, psicológicas, sociológicas y, fundamentalmente, políticas (cómo compaginar la libertad individual con una distribución equitativa de la riqueza; binomio libertad/igualdad) en las que se sustenta su teoría de la justicia.

El primer capítulo «Naturaleza y función del sentido de la justicia» comienza por delimitar la idea de personalidad moral («se trata de apuntalar la idea de que la humanidad tiene una naturaleza moral»). Aquí se manifiesta la deuda de Rawls con Piaget y Kohlberg en relación con las fases del desarrollo moral del individuo. La personalidad moral se funda en la posesión de una doble capacidad: 1) capacidad del sentido de la justicia basado en el principio de la inviolabilidad individual; 2) capacidad de una concepción del bien que se concreta en una formulación reflexiva de un proyecto racional de vida. Un papel destacado dentro de este capítulo lo ocupa la tarea de distinguir el significado de la justicia «en sentido cognoscitivo» (p. 35 y ss.) del sentido de la justicia ideal; este último tiene un carácter regulativo.

El capítulo segundo «Justicia y reciprocidad» trata de extraer las consecuencias de una tesis básica de Rawls: la justicia como reciprocidad, que el opone al militarismo. A tal efecto, se analizan una serie de presupuestos psicológicos (tributarios de Piaget) y su conexión con la concepción de la justicia como equidad. Las ideas de equilibrio y estabilidad presiden toda esta reflexión («La justicia como equidad es un hecho psicológico consti-

\section{AGUILÓ REGLA, J.; ATIENZA, M.; LÓPEZ RUIZ, F. y RUIZ MANERO, J.}

173 preguntas de introducción al Derecho.

Ed. Universidad de Alicante, 1985, 93 págs.

Estas 173 preguntas (y respuestas) pretenden ofrecer a los estudiantes de primer curso un material didáctico que les resulte útil de cara a la preparación del programa de la asignatura «Introducción al Derecho». Así, mediante el sistema de pregunta-respuesta -que evidentemente necesita ser complementado, dado que por si sólo no puede garantizar una adecuada formación del estudiante- van apareciendo en el libro los diferentes temas de la asignatura: el concepto de Derecho (problemas de definición, cuestiones de ambigüedad y vaguedad, Derecho y normas, Derecho y Estado, Derecho y poder, Derecho e ideología); las funciones del Derecho (análisis funcional del Derecho, funcionalismo y conflictualismo, el Derecho como sistema de control social y el Derecho como factor de cambio social); los valores jurídicos (igualdad, libertad y seguridad, concepciones acerca de la justicia y concepto y fundamentación de los derechos humanos); la ciencia del Derecho (origenes y desarrollos, ciencia y teoría de la ciencia, la cientificidad de la jurisprudencia); la situación actual de los saberes jurídicos (sociología del Derecho, lógica jurídica, informática jurídica, filosofía del Derecho); la teoría general del Derecho (el Derecho como sistema normativo, los conceptos básicos del Derecho, teoría de la fuentes, la interpretación del Derecho); la historia de las ideas iusnaturalistas. 
tutivo de la naturaleza humana y condición necesaria de la sociabilidad», p. 65). La idea implícita en la concepción de la justicia como equidad es, a juicio de la autora, que esta idea sea capaz de generar en los ciudadanos la convicción de que la dignidad e igualdad no están reñidas con sus capacidades naturales y status social. El capítulo tercero esta dedicado a indagar las raíces sociológicas de la construcción de Rawls. Bajo el epígrafe «El problema del orden social y la crítica al utilitarismo», tras una crítica al militarismo, pasa revista a las concepciones emparentadas con la teoría de la justicia de Rawls, el estructural funcionalismo de Parsons (como teoría legitimadora de las instituciones sociales en los países desarrollados), y el interaccionismo simbólico de Mead. El capítulo cuarto «Individualismo y contractualismo» comienza con una breve reexposición de Parsons, para, a continuación, examinar ideas claves de la teoría de Rawls: «igualdad y reciprocidad en la justicia como equidad», «los bienes primarios», «prácticas sociales y estructura basica de la sociedad», para terminar este capítulo refiriéndose a la desobediencia civil, no sin antes hacer mención, desde el punto de vista político, a la teoría de la justicia de Rawls calificandola de «socialdemócrata», en tanto que es un intento de corregir las graves deficiencias del liberalismo practicado a ultranza.

Cierran este libro unas «Consideraciones finales», en las que la autora resume las conclusiones del propio trabajo y ofrece la siguiente valoración de conjunto de la obra de Rawls: «la justicia como equidad es una justificación moral del individualismo institucionalizado y una defensa de la sociedad pluralista moderna» (p. 162 in fine).

(F. L. R.) 


\section{ÁLVAREZ CAPEROCHIPI, José A.}

\section{Lutero y el Derecho.}

Persona y Derecho, Pamplona, n. ${ }^{\circ}$ 13, 1985, págs. 18-59.

En este artículo se trata de defender la tesis siguiente: «en Lutero se encuentra el fundamento del Derecho y de la historia moderna». El autor enumera con brevedad los principios teológicos luteranos, poniendo de relieve cómo éstos han influido de manera decisiva en el Derecho, la Filosofía y la Política modernas. A su juicio, una de las tesis básicas de la doctrina de Lutero es el fideismo: la fe, por sí misma, trae consigo la salvación a Dios se llega sólo a través de la fe. Obviamente, este planteamiento trae consigo el incremento de la separación existente entre razón y fe, que se había comenzado a gestar en el siglo XIV. Otra implicación igualmente importante de esta doctrina de la separación de razón y fe, es que se generan dos tipos distintos de relación: las relaciones con la naturaleza y las relaciones intersubjetivas que están fundadas en la razón, y las relaciones con Dios, que se basan en la fe.

Por lo que se refiere a las consecuencias de la obra de Lutero en el ámbito jurídico-político, habría que destacar las siguientes: a) mientras que la fundamentación escolástica de la Moral y del Derecho descansaba en la ley como adecuación aun orden preestablecido por el Creador, Lutero sostenía la doctrina de la incognoscibilidad de Dios, lo cual suponía un giro radical en este tema: la ley tendrá su fundamento en el poder del soberano; b) aparece la idea de «libertad legal» como «el resultado de una imposición normativa del poder político. El hombre se encuentra ante el Derecho como ante la naturaleza; la ley jurídica no es esencialmente distinta de la ley física»; c) el Estado se convierte en fuente de toda legalidad asumiendo el monopolio de la producción normativa; d) la ley establece el criterio de distinción entre el bien y el mal.

\section{ARA PINILLA, Ignacio.}

\section{Sobre los temas de la Filosofía del Derecho.}

Cuadernos de la Facultad de Derecho, Palma de Mallorca, n. ${ }^{\circ} 11,1985$, págs. 9-25.

Este artículo constituye un extenso comentario al libro de Gregorio Peces Barba Introducción a la Filosofía del Derecho. Para ello, Ignacio Ara sigue la sistemática del libro, que está dividido en dos partes: Sobre el Derecho (Derecho y poder, Derecho y realidad social, Derecho y otros sistemas normativos) y Sobre la Filosofía del Derecho (Teoría del Derecho, Teoría de la ciencia jurídica, Teoría de la justicia), y va desgranando y exponiendo capítulo por capítulo las tesis del profesor Peces Barba, incluyendo comentarios a las mismas. Por último, el amor concluye que «Las observaciones realizadas nos permiten comprobar que el libro..., lejos de pretender un tratamiento exhaustivo de los temas, se ha mantenido dentro de las exigencias que cualquier Introducción comporta, renunciando incluso a la tentación de extenderse, como muy bien ha hecho en otros trabajos de la especialidad, en el análisis de los argumentos que le son más queridos, y armonizando con pulcritud la enunciación de los temas a investigar con la profundización en tesis originales y el apunte de propuestas que permitirán al estudioso de la Filosofía del Derecho disponer de un abanico organizado de áreas de investigación y de unos materiales donde la pluma del Profesor de la Universidad Complutense abona terrenos en los que muchas veces la cosecha ha sido por él mismo recogida con anterioridad yen otros garantiza que la prosecución por la vía 'integradora y no desintegradora' que él nos abre constituye el mejor camino para la consecución de las metas que cualquier investigador de los temas de Filosofía del Derecho ha de proponerse».

(J. A. R.)

ATIENZA, Manuel.

Algunas tesis sobre la analogía en el Derecho.

Doxa, Alicante, n. ${ }^{\circ}$ 2, 1985, págs. 223-229.

Resumiendo un trabajo más extenso, de próxima publicación, (Sobre la analogía en el Derecho. Ensayo de análisis de un razonamiento jurídico) a lo largo de veintidós tesis -relacionadas entre sí, pero cada una independiente y con sentido propio- el amor desentraña las posibilidades y riesgos, aclara malentendidos y matiza el uso de la analogía en los procesos de interpretación, aplicación, descripción y explicación del Derecho. En particular considera la analogía como un mecanismo necesario para la innovación de cualquier ordenamiento jurídico, y cuyo uso implica necesariamente creación o innovación del Derecho, permitiendo la adecuación de un sistema constituido por normas fijas a un medio social en constante transformación. Por otro lado, rechaza que la analogía sea fuente -en el sentido habitual- del Derecho, y considera fuente no a la analogía misma, sino a la norma creada por el procedimiento analógico. Muestra también que la analogía es un instrumento de la justicia formal, pues el uso de la misma (el argumento «a simili») se basa en el principio de igualdad que prescribe que se deben tratar igual los casos semejantes. Y apunta, por último, las vías por donde debe encaminarse una futura investigación sobre la analogía en el Derecho, la cual deberla tratar de articular en un sistema unitario «las técnicas de inteligencia artificial aplicables al Derecho, la teoría de los subconjuntos borrosos y las lógicas de la vaguedad que se están construyendo sobre esta base, el instrumental lógico -análisis de las normas, de las oposiciones deónticas, etc.- proporcionado por la lógica deóntica, y los criterios de racionalidad práctica que se tratan de elaborar a partir de una teoría de la argumentación jurídica». 
Por lo que concierne al Derecho privado, el autor hace referencia a dos instituciones: la propiedad y el matrimonio. Respecto de la primera afirma que: «sólo después de la Reforma, y por influencia del individualismo metodológico, pasa a considerarse la propiedad como derecho subjetivo». Concluye el artículo con unas referencias a la institución matrimonial comparando la concepción católica con la luterana.

(L. A. G. P.) 


\section{Introducción al Derecho.}

Ed. Barcanova, Barcelona, 1985, 377 págs.

El objetivo fundamental de esta obra es presentar una introducción amplia al Derecho ya los saberes jurídicos que de cuenta del carácter complejo y multiforme de lo jurídico. El esquema seguido para ello es, sin embargo, bastante simple. Los tres primeros capítulos se agrupan en torno ala pregunta ¿qué es el Derecho?, y pretenden ofrecer tres respuestas distintas según se adopte una perspectiva estructural (¿cómo está estructurado el Derecho?, ¿cuáles son los elementos que lo integran?), funcional (¿para qué sirve?, ¿qué funciones cumple en la sociedad?) o valorativa (¿cómo debería ser el Derecho?, ¿cuándo un Derecho es justo?). Los dos últimos capítulos buscan su unidad en torno a la pregunta ¿qué es la ciencia del Derecho?; la respuesta varía en este caso según se tome en consideración el saber jurídico tradicional (¿qué tipo de actividad intelectual es la dogmática jurídiça?, ¿tiene o no carácter científico?) o biẹn se amplíe la perspectiva para incluir otras disciplinas como la sociologia del Derecho, la lógica jurídica, la informática jurídica o la filosofía del Derecho (¿cuál es la situación actual de todos estos saberes jurídicos?, ¿qué relación guardan entre sí y con la dogmática jurídica?).

La adopción de esta perspectiva general tiene que ver con la intención del autor de dirigirse a un público amplio. Por un lado, pretende ofrecer una serie de materiales para usar en un curso de Introducción al Derecho que sustituya al anacrónico Derecho Natural que aún sigue figurando en los planes de estudio de las Facultades de Derecho españolas. Por otro lado, desearía contribuir a facilitar un mayor intercambio y conocimiento mutuo entre los juristas y los filósofos y científicos sociales.

\section{ATIENZA, Manuel y RUIZ MANERO, Juan.}

\section{Marxismo y ciencia del Derecho.}

Sistema, Madrid, n. ${ }^{\circ}$ 64, enero 1985, págs. 344.

El artículo trata de «ver si existe o no una ciencia jurídica marxista y, exista o no, indagar que es lo que el marxismo puede aportar (aunque sea en forma negativa, es decir, como crítica) a la ciencia jurídica». En un primer apartado, los autores examinan las dificultades que, en el contexto del marxismo, presenta la posibilidad misma de una ciencia jurídica (la carencia de autonomía del Derecho, su carácter ideológico, la propuesta de su extinción) así como la ambigüedad de la concepción marxiana de la ciencia.

A continuación, pasan revista a algunas de las concepciones de la ciencia jurídica sostenidas por autores marxistas tanto del Este como del Oeste: E. Pasukanis, R. Lukic, U. Cerroni, B. Edelman y M. Miaille.

Respecto a Pasukanis destacan que el modelo de ciencia del que parte obedece a la noción hegeliano-marxista de la ciencia como dialéctica, lo que implica que su teoría no puede calificarse como científica en el significado usual de este término. Ello no obstante, la teoría general del Derecho de Pasukanis presenta, a juicio de los autores, aspectos positivos: pues su historicismo puede «proporcionar un correctivo importante a la tendencia de la teoría general del Derecho normal a analizar los conceptos jurídicos desde una perspectiva exclusivamente abstracta y ahistórica». Y, en este sentido, escriben que «los análisis efectuados por Pasukanis de los conceptos de Derecho público y Derecho privado, de Derecho objetivo y derecho subjetivo siguen teniendo, en nuestra opinión, un interés no simplemente erudito».

La obra de R. Lukic es presentada como «un mixtum de discurso jurídico tradicional e ingredientes marxistas (...) cuyos dos elementos no se encuentran siempre bien trabados» que se resuelve en «una verdadera summa de arcaísmo y de caos y confusión conceptuales».

\section{BALLESTEROS, Jesús.}

\section{Paz, desarme, libertad: obstáculos económicos e ideológicos.}

Anuario de Filosofía del Derecho, Madrid, n. ${ }^{0} 2$, 1985, págs. 65-75.

«Si vis pacem, para bellum». Este aforismo resume la doctrina de la disuasión, que ha sido la justificación de los Estados a la escalada armamentista en sus relaciones internacionales; débil argumento que pretende desterrar la violencia con la violencia. Prueba de ello es el cambio experimentado en las estrategias político-militares de los dos bloques: se ha pasado de la estrategia de la disuasión a la estrategia del exterminismo como consecuencia de la acumulación de una potencia destructiva superior a la necesaria para destruir al enemigo, excediendo por tanto la declarada función defensiva.

¿Cuál es la causa, entonces, del aumento de los gastos militares? En otras palabras ¿a quién beneficia? En los ÉE.UU. nos encontramos con grandes compañías dedicadas a la fabricación de armas, compañías que integran el llamado «Complejo Militar Industrial» y obtienen enormes beneficios con sus ventas al Pentágono. Así pues, puede afirmarse que económicamente «la principal responsabilidad del armamentismo recae sobre las grandes compañías norteamericanas de armamentos, y sobre los grandes traficantes de armas». Por otro lado, la U.R.S.S. ve «racionalizada» su hegemonía frente a disidentes y aliados, favoreciendo su anquilosamiento burocráticototalitario. En consecuencia, para la U.R.S.S. las ventajas son de índole política.

Si hasta aquí se han analizado las causas reales de la carrera de armamentos, el autor, a continuación, pasa a tratar de los criterios de justificación de ésta, que enmascaran, al mismo tiempo, tales causas. Ambos bloques mantienen una actitud maniquea al calificar siempre al contrario de «culpable». De esta forma «cada aumento de gastos en la carrera es presentado como realizado previamente por el enemigo, que en definitiva acaba realizando finalmente y así indefinadamente». 
De la obra de U. Cerroni se subrayan las grandes analogías que sus planteamientos presentan con los de Pasukanis; el que sus escritos -a diferencia de lo usual en los marxistas contemporáneos- se asientan en un buen conocimiento de la teoría jurídica del siglo XX y, finalmente, el carácter fuertemente prescriptivo del modelo de ciencia jurídica propuesto por Cerroni así como que tal modelo «parece demasiado ambicioso para ser operativo».

Los trabajos de B. Edelman y M. Miaille son presentados como la aplicación al campo jurídico de la interpretación del marxismo llevada a cabo por L. Althusser. Se ponen de relieve, así, algunos rasgos del pensamiento althusseriano particularmente presentes en las obras de aquéllos (la tesis de la ruptura epistemológica, el entendimiento del concepto marxista de totalidad como radicalmente diverso de su correspondiente hegeliano, la consideración de la noción de sujeto como noción central del discurso ideológico). La aplicación del marxismo althusseriano al campo del Derecho llevada a cabo por Edelman y Miaille no ha sido, a juicio de los autores, demasiado fructífera: a propósito de Edelman, escriben que su aportación «no va más allá del redescubrimiento de algunos lugares comunes y de la crítica a autores escasamente representativos del pensamiento jurídico actual»; de Miaille, señalan que no aporta nada que no se encontrara ya en autores marxistas de finales del XIX o, por lo que hace a la vertiente más propiamente jurídica, en Pasukanis.

La conclusión general más importante del conjunto del trabajo es «el escaso desarrollo de las diversas líneas de investigación que ofrece el marxismo a la ciencia jurídica, especialmente en cuento ciencia social (no tanto en cuanto ciencia normativa )». Desde Pasukanis -concluyen- no parece que haya existido un progreso apreciable del programa de investigación marxista en el terreno del Derecho.

Para salir de esta situación se requiere una nueva forma de pensar, que para el profesor Ballesteros se concreta: en lo económico, en la conciencia de la necesidad de establecer un verdadero «nuevo orden económico internacional» en el que la solidaridad sustituya a la competencia y se reconvierta a las industrias de armas en otras de mayor utilidad social; en lo político, en la lucha contra la «burocratización del mundo» (mediante la exigencia de información veraz y transparente y posibilidad de disidencia, con lo que las cuestiones de importancia para todos puedan ser decididas por todos) y en el ámbito internacional en el necesario desbloqueo de las relaciones Este-Oeste; y en lo cultural, en el desplazamiento de la «ideología de la técnica» para prestar una mayor atención a la persona.

(A. D. P.) 


\section{BAURMANN, Michael y KLIEMT, Hartmunt.}

¿Tomar a la ligera el positivismo jurídico? (Trad. de Javier de Lucas).

Doxa, Alicante, n. ${ }^{\circ} 2$ 2, 1985, págs. 167-185.

Se trata de una crítiça a la traducción alemana del libro de Ronald Dworkin Taking Rights seriously, en el que se discuten las tesis jurídico-positivistas de H.L.A. Hart. Hart, como se sabe, reconduce la idea matriz kelseniana del imperativo coercitivo o sancionador de la norma, observando que, además de las «normas primarias» o que obligan a actuaciones concretas, hay otras «secundarias», que tienen por objeto la aplicación de aquéllas, bien facultando a personas o grupos para decidir si se produce el quebrantamiento de normas vinculantes, bien regulando procedimientos para su aparición, o bien identificando tales normas vinculantes, las que pertenecen al sistema jurídico, mediante lo que el propio Hart llama «regla de reconocimiento». Dworkin combate la propuesta de Hart, y en particular defiende la imposibilidad de distinguir entre criterios morales y jurídicos, pues para el el problema del Derecho vigente es una cuestión de «principios morales», y ataca la «regla de reconocimiento» para la identificación empírica del Derecho positivo, por su excesiva indiferenciación y sencillez, por su irrelevancia, por entender -a fin de cuentas- que no satisface la inclusión en el ordenamiento de los «principios jurídicos», como especie aparte y distinta de las reglas jurídicas.

Por su parte, Baurmann y Kliemt, para demostrar la inconsistencia de estas objeciones, acuden a la observancia de la práctica jurisprudencial, donde tan importante son los «precedentes» $\mathrm{y}$ «preceptos de Derecho escrito», resaltando que cuando el Juez los toma en consideración, evidentemente suspende su autonomía de juicio moral. Es ahí donde juega su papel la «regla de reconocimiento». Y en cuanto a la argumentación sobre los «principios jurídicos», los autores de este trabajo los consideran identificables mediante una regla de reconocimiento positiva, puesto que, en todo caso, son sustentados por fuentes del Derecho que objetivizan su utilización.

\section{BOBBIO, Norberto.}

8 preguntas a Norberto Bobbio (Entrevista realizada por Manuel Atienza y Juan Ruiz Manero).

Doxa, Alicante, n. ${ }^{\circ} 2$, 1985, págs. 233-246.

En esta entrevista realizada por M. Atienza y J. Ruiz Manero, Bobbio responde a 8 preguntas que le dan pie para referirse a un conjunto de cuestiones diversas que abarcan temas relacionados con su biografía política (sus experiencias bajo el fascismo, la influencia que ejercieron sobre él Croce y Gobetti, su militancia en el Partido d'Azione, su abandono de la políícica tras la caída del fascismo y su reciente regreso a la misma), con sus intereses intelectuales (abandono de la teoría general del Derecho en beneficio de la filosofía política), con sus actitudes políticas (el diálogo con la extrema izquierda, la crisis de actual Estado del bienestar, las tendencias manchesterianas de los partidos socialistas, el papel del PCI), con sus actitudes ante los problemas de la paz (polémica con J. Galtung), y, por último, con su valoración sobre el porvenir del marxismo.

\section{BOBBIO, Norberto.}

\section{El equilibrio del terror. (Trad. de Alfonso Ruiz Miguel).}

Anuario de Filosofía del Derecho, Madrid n. 2, 1985, págs. 5-17.

El equilibrio del terror ha de considerarse como manifestación extrema y versión actual del equlibrio de poderes. Extrema y actual porque no se refiere tanto a la par en general como a la «suspensión sine die de la guerra nuclear».

Para Hobbes el temor recíproco induce a los individuos a salir del estado de naturaleza creando un poder supraindividual que les proteja «por las fuerzas de todos»: el Leviathan, el Estado. Pero el temor subsiste en las relaciones internacionales ( «Un Estado territorialmente limitado no elimina la guerra universal de todos contra todos»). ¿Por qué, pues, ese temor no induce a los Estados a instaurar un poder supraestatal?

Expuestas estas ideas, el profesor Bobbio analiza la doctrina del equilibrio del terror. Según ella, en las relaciones entre Estados con intereses incompatibles es la igualdad de fuerzas la que garantiza la paz a través de la estrategia de la disuasión, entendida como la política consistente en demostrar al adversario que se está preparado para una defensa tal que los costos de una agresión serían superiores a las ventajas. Y actualmente el efecto disuasorio de las armas atómicas haría, no ya improbable, sino imposible la guerra nuclear.

La doctrina del equilibrio del terror desde la filosofía de la historia se relaciona con la concepción de la heterogénesis de los fines y empíricamente trata de sostenerse por sus defensores apelando a los decenios de paz transcurridos desde la segunda guerra mundial. Pero ¿habria estallado inevitablemente una tercera guerra si no se hubiera instaurado, gracias a las armas nucleares, el equilibrio del terror? 
Termina el artículo con la defensa de la distinción entre Derecho y moral y, consecuentemente, del concepto positivista del Derecho, que permite a su vez una mejor critica al Derecho positivo, incluso desde el punto de vista moral.

(A. A. .L.)

Para el autor, en la doctrina analizada se advierte la siguiente paradoja: las armas nucleares serían construidas con la precisa intención de no ser usadas, pero sólo impiden la guerra nuclear, (no la convencional, para la que su existencia a inexistencia es indiferente).

Con respecto a la situación actual. Bobbio advierte que la humanidad vive bajo el equilibrio del terror, equilibrio muy inestable, de eficacia sólo parcial y que cambia al compás de una carrera ascendente de armamento que sólo se detendrá con la ruptura de la tregua o con la creación de una instancia supraestatal」

De todo ello, el profesor Bobbio concluye que la doctrina del equilibrio del terror no es más que un intento de justiticación de la conducta irresponsable y éticamente viciada de las grandes potencias actuales.

(D. G. L.) 


\section{BOBBIO, Norberto.}

Estudios de historia de la filosofía: de Hobbes a Gramsci. (Introducción de Alfonso Ruiz Miguel y Trad. de Juan Carlos Bayón).

Ed. Debate, Madrid, 1985, 365 págs.

Este libro -inédito como tal en Italia- recoge un conjunto de ensayos del Prof. N. Bobbio sobre historia del pensamiento político tanto moderno como contemporáneo, escritos entre 1957 y 1981 . El volumen arranca con un extenso trabajo, El modelo iusnaturalista, sobre los modos iusnaturalistas de concebir la sociedad y el Estado. El segundo trabajo, Hobbes y el iusnaturalismo, parte de la constatación de que «se está difundiendo la conviccion de que el iusnaturalismo moderno no comienza con Grocio, sino con Hobbes» (pág. 151) y, en esta línea, concluye que «Lo cierto es que Hobbes inventa, elabora y perfecciona los más refinados ingredientes iusnaturalistas... El iusnaturalismo moderno pasa, es cierto, por Hobbes, pero se afirma sólo con Locke» (pág. 170). En el tercer ensayo, Vico y la teoría de las formas de gobierno, Bobbio hace una exposición de la teoria viquiana recurriendo a los tres posibles fines que puede cumplir cualquier sistema conceptual construido en el campo de las disciplinas históricas y sociales: a) describir y clasificar las formas de gobierno que se han dado historicamente (descriptivo); b) expresar una preferencia por una de las formas sobre las demás (prescriptivo); c) describir (o prescribir) las etapas del movimiento histórico, cuando las diferentes formas están dispuestas en orden cronológico (histórico, que a su vez puede ser descriptivo o prescriptivo). En Kant y las dos libertades se pone de manifiesto como Kant maneja ambos conceptos de libertad -como autodeterminación individual (liberal) y como autodeterminación colectiva (democrático)- sin llegar nunca a distinguirlos claramente. En el quinto trabajo, Derecho privado y Derecho público en Hegel, el autor muestra cómo a cada tipo de obras (sistemáticas, históricas y polémicas) de Hegel corresponde un uso diferente de la distinción entre los

BOBBIO, Norberto.

\section{La razón en el Derecho (Observaciones preliminares). (Trad. de Alfonso Ruiz Miguel).}

Doxa, Alicante, n. ${ }^{\circ} 2$, 1985, págs. 17-26.

El artículo (ponencia inaugural del Congreso «La ragione nel Diritto», celebrado en Bolonia en diciembre de 1984) se puede dividir en dos partes. En la primera, Bobbio trata de acotar las relaciones razón-Derecho («ley de la razon»/《razón jurídica»; «razón legisladora» o fuerte/〈razón juzgadora» o débil) y afirma que el problema del Derecho como producto de la razón fue olvidado a principios del siglo XIX.

La segunda parte trata de establecer los puntos comunes que existen entre las distintas concepciones del Derecho racional. Afirma Bobbio que existen tres ejes básicos a todas las teorías racionalistas, que consisten en distinguir el Derecho de la revelación divina, de la voluntad superior y de la experiencia histórica.

Para Bobbio, a pesar de la gran cantidad de usos que se han atribuido al termino razón, es posible encontrar un factor común en todos ellos (razón = máximo órgano del conocimiento humano), y esto le permite abordar dos cuestiones:

-la persistencia del nexo razón-Derecho: para Bobbio existe una definición mínima de Derecho («conjunto de reglas de conducta que induce al hombre a una convivencia ordenada»). Sólo existirá ésta si existen unas leyes generales inscritas en el orden universal, que la razón debe descubrir;

-la crisis del Derecho racional en un momento de la historia: con la introducción del método positivo y del método histórico, «la idea del Derecho natural se licuó y la escisión entre Derecho y razón quedó irremediablemente consumada».

\section{CALABRESI,Guido.}

Sobre los límites de algunos análisis «no económicos» del Derecho.

Anuario de Filosofía del Derecho, Madrid, n. ${ }^{\circ}$ 2, 1985, págs. 221-228.

El autor, en primer lugar, realiza una confrontación de las ventajas y defectos del método del análisis económico del Derecho frente a otras metodologías imperantes en los Estados Unidos. El primero de estos métodos es el del análisis lingüístico del Derecho que, según el autor, «concede una importancia, ciertamente extraña, al modo normal de hablar. Como si el modo de hablar naciera antes que las relaciones sociales... y fuera independiente de ellas. Como si fuera posible afirmar que es necesario realizar ciertas cosas porque se habla de determinada manera, en vez de advertir que ésta es el modo de describir lo que hacemos dadas unas relaciones legales». El segundo método es el referido al Legal Process, que si bien, en opinión del autor, posee cierto valor, «en la medida en que no se pregunta, dado un sistema social y político, quien puede responder mejor a ciertas aspiraciones, a ciertos deseos de la sociedad, jamás nos dice qué resultados se deben obtener, ni hacia dónde debemos encaminarnos. En consecuencia, como método jurídico, como crítica, produce una enorme sensación de vacío». El tercer método es el de la crítica ideológica al Derecho, que resulta útil en la medida en que pone de manifiesto a qué grupos sirve el Derecho, pero se revela absolutamente inútil cuando se trata de proceder a la reconstrucción del Derecho. El cuarto metodo es el filosófico, y el principal problema que plantea «es la tendencia a describirlo todo en términos de justicia, en términos absolutos; términos que a la postre no resultan ciertos. Luego cuando con este método tratamos de acercarnos a la realidad, afirmando que en ella los derechos no son absolutos, sino contingentes, y por consiguiente debemos sustituir las nociones absolutas por otras contingentes, nos encontramos con que aquél (el método) ya no nos sirve porque se han esfumado los puntos de 
Derechos y que los tres usos tienen en común el significado valorativol de los dos términos: Derecho privado representa siempre el momento inferior o negativo y Derecho público el momento superior o positivo. El siguiente ensayo, Marx、 marxismo y relaciones internacionales, parte de la constatación de que la polémica sobre si existe una teoría marxista del Estado se ha referido casi exclusivamente al problema del Estado en sus relaciones internas; la cuestión que aquí plantea Bobbio es la de si existe o no una teoría marxista de las relaciones internacionales. En el capítulo séptimo, Estado y Poder en MaxWeber] se examinan algunos temas de la teoría política de Weber-el último clásico en opinión de Bobbio- confrontándolos con «lo que he llamado 'los temas recurrentes' del pensamiento político, dedicando especial atención a aquellos amores cuyas teorías acompañan la formación del Estado moderno» (pág. 260). En el octavo capítulo, Mosca y la ciencia política, Bobbio analiza primordialmente el método, el objeto y el fin de la concepción de la ciencia política en este amor. En Pareto y la crítica de las ideologías se pone de relieve que là clave sistemática de la obra de Pareto consiste en considerar a las ideologías bajo tres aspectos: el objetivo, el subjetivo y el de la utilidad; y de ahí pueden extraerse dos tesis: a) toda ideología puede ser considerada según su grado de verdad (aspecto objetivo), según su grado de eficacia (aspecto subjetivo) y según su grado de utilidad (aspecto de la utilidad) y b) cada uno de estos criterios es independiente. En el último ensayo, Gramsci y la concepción de la sociedad civil, Bobbio pone de manifiesto que la clave para alcanzar una interpretación articulada del sistema conceptual gramscianol «es el reconocimiento de que 'sociedad civil' es uno de los dos términos no de una sola antítesis, sino de dos antítesis diferentes» (pág. 364): como término de la antítesis estructura-superestructura y como momento de la superestructura.

Es de resaltar también el extenso trabajo introductorio de Alfonso Ruiz Miguel, Filosofía de la historia e historid dela filosofía en N. Bobbio, que suministra al lector las claves para comprender la tarea intelectual de Bob-1 bio en sus trabajos histórico-filosóficos.

(J. A. R.)

referencia». Por último, se refiere al método formalista o dogmático, cuyo problema «es que a la postre se convierte inevitablemente en un método histórico, en un método con el cual aquello que se ha realizado en el pasado se percibe como un dogma que ahora se desarrolla, o se modifica, haciéndose más coherente, sin que en ningún momento la estructura deje de ser la del pasado». Tras esta confrontación el amor concluye que el análisis económico del Derecho está en una posición prevalente, «pues a pesar de todos sus defectos, ninguno de los métodos alternativos consigue derrotarlo en la discusión de cuestiones prácticas del Derecho». El artículo incluye también una breve exposición sobre la relación entre eficiencia y justicia. 


\section{CALSAMIGLIA, Albert.}

De nuevo sobre la guerra y la cooperación.

Anuario de Filosofía del Derecho, Madrid, n. ${ }^{\circ} 2,1985$, págs. 44-63.

En este artículo el autor propone una alternativa a las tesis del pacifismo jurídico basadas fundamentalmente en el artificio contractualista y en la necesidad de construir un supraestado que garantice la paz. Para lograr su objetivo utiliza la teoría de la cooperación de R. Axelrod basada en la teoría de los juegos y la aplica a la carrera de armamentos. El trabajo parte del análisis del juego del dilema del prisionero reiterado y de ese modelo extrae una serie de conclusiones.

La tesis principal del artículo es que la cooperación podría surgir si los Estados persiguieran sus intereses egoístas y fueran fieles al postulado de la defensa. Sin embargo, la cooperación para la paz no surge porque la función principal de la carrera armamentista no es defensiva sino agresiva. Si los objetivos fundamentales de los Estados fueran defensivos la propuesta de la cooperación sería mejor que la del supraestado. El autor trata de argumentar las razones que justifican su preferencia y también las razones que impiden la emergencia de la cooperación. El trabajo trata de averiguar cómo es posible que surja la cooperación entre individuos que no tienen especiales relaciones de amistad y que persiguen sus propios intereses y cuáles son las causas que impiden el desarrollo de la cooperación en el tema armamentista.

\section{CALSAMIGLIA, Albert.}

\section{¿Por qué es importante Dworkin?}

Doxa, Alicante, n. ${ }^{\circ} 2$, 1985. Págs. 159-165.

La obra de Ronald Dworkin constituye -en opinión de Albert Calsamiglia- una de las aportaciones más valiosas de la filosofía jurídico-política norteamericana actual, por cuanto representa una alternativa a la ciencia general del Derecho dominante, que pone en tela de juicio presupuestos profundamente arraigados en la mentalidad de los juristas, circunstancia esta última que lo convierte en un autor incómodo. La crítica a la filosofía militarista -una de las manifestaciones más relevantes de la filosofía liberal- y a la jurisprudencia analítica -que es la expresión más acabada de la teoría jurídica liberal- ocupa un lugar muy importante en su obra como prolegomeno de un nuevo liberalismo igualitarista. Frente a ella propugna una teoría alternativa de los derechos como fundamento de su parte normativa y la necesidad de relacionar el pensamiento moral con el pensamiento jurídico, destruyendo el tradicional aislamiento entre los juristas y otros especialistas sociales. Calsamiglia, comọ colofón a su breve estudio sobre la figura de Dworkin, estima que las preocupaciones de ese autor no son ajenas al Derecho continental, rebatiendo las opiniones expresadas en sentido contrario.

(S. M. .A.)

\section{CALSAMIGLIA, Albert.}

\section{Sobre la teoría general de las normas.}

Doxa, Alicante, n. ${ }^{\circ} 2,1985$, págs. 87-105.

Albert Calsamiglia efectúa aquí una reflexión acerca de la última obra de Kelsen, que en su opinión introduce un conjunto de importantes cambios respecto de su teoría pura del Derecho. Estos cambios los resume en tres apartados fundamentales: la norma fundamental, las relaciones entre lógica y Derecho y el supuesto logicismo e irracionalismo de su obra póstuma.

En lo que se refiere a la norma fundamental, ésta cambia su cualificación filosófica. Se mantiene su necesidad entendiéndola ya no como una hipótesis, sino como una ficción, en el sentido de la filosofía del «como si» de H. Vaihinger. Además se reconoce que las normas pueden adquirir validez por un camino distinto al de la norma fundamental. El aspecto de la justificación de la obediencia al Derecho viene dado por la suposición de esta misma norma fundamental, pero a ello se le criticará el que se trate de una tautología.

El apartado de las relaciones entre lógica y Derecho ofrece el cambio sustancial de que Kelsen considerará inadecuada la técnica de la aplicación indirecta de la lógica a las normas jurídicas. La lógica no se podrá aplicar de ninguna forma sobre las normas.

Por último, en «La Teoría General de las Normas» Kelsen rompe con el logicismo que habrá defendido hasta ese momento, según el cual el Derecho era un sistema carente de contradicciones, y reconoce que las propiedades de la ciencia del Derecho no tienen por qué coincidir con las del propio Derecho.

(R. D. .F.) 
CALVO GONZÁLEZ, José.

La fuerza normativa de lo fáctico en materia urbanística.

Revista de Derecho Urbanístico, n. ${ }^{\circ}$ 92, marzo-abril 1985, págs. 67-72.

En cuanto las normas jurídicas representan el más elevado grado de abstracción de la experiencia jurídica, sus soluciones y decisiones generan a veces excesivas reducciones de la realidad que tratan de ordenar con lo que, a falta de más particulares referencias sociales, empíricas o fácticas orientadoras, las hay que persisten inopinadamente o bien que en su enorme complejidad técnica son incorrectamente aplicadas. Este pensamiento inspira el breve comentario dedicado a la obligación impuesta al amparo de la Ley de Reforma de la Ley sobre Régimen del Suelo y Ordenación urbana -2 de mayo de 1975- y específicamente contenida en el art. 83, 3 b) de su Texto Refundido -9 de abril de 1976- sobre cesión a los Ayuntamientos, con carácter gratuito, del $10 \%$ del aprovechamiento medio del que resulte «suelo urbanizable programado» dentro de los límites de un territorio municipal, y acerca subsiguientemente de la definición del régimen jurídico del suelo urbano, como cuestiones ambas imbricadas por la influencia de apreciaciones fácticas o físico-reales con fuerza normativa en materia urbanística, en expresa referencia a la doctrina jurisprudencial del Supremo contenida en las sentencias de 23 de marzo de 1982, 2 y 3 de junio siguiente, 28 de diciembre de 1983 y 14 de marzo de 1984 . La reflexión así dispuesta se encamina a hacer de la investigación iusfilosófica sobre la praxis jurídica, un campo abierto al intento de elaborar una metateoría de la realidad y técnica jurídicas en la que si no llegando a asumir posiciones metodológicas tan concretas como las de Luhmann -es decir, la de construir el sistema y la dogmática jurídica sobre «conceptos jurídicos adecuados a la sociedad» donde los hechos y estructuras sociales queden incluidos en los modelos jurídicos que los conducen de forma normativa decidible -al menos se depure en lo posible

\section{CALVO GONZÁLEZ, José.}

Notas sobre la recepción de la teoría institucional en la doctrina iuspublicista española.

Cuadernos Informativos de Derecho Histórico Público, Procesal y de la Navegación, n. o 1, 1986, págs. 29-49.

Este trabajo contiene el estudio de la recepción que las fuentes y la teoría institucional del Derecho tuvieron en nuestro país, concretándolo en el ámbito del Derecho Público con particular mención de las disciplinas de Derecho Político, Administrativo, Procesal y Público Eclesiástico. Respecto a las fuentes, puede afirmarse que su recepción fue tardía, desigual e incompleta. Sin embargo, la clara despreocupación editorial por difundir los textos fundamentales del institucionalismo jurídico contrasta vivamente con el eco y estimable nivel de aceptación alcanzado en la doctrina iuspublicista española. El panorama interdisciplinar que sobre ella se construye permite concluir tres reflexiones generales. Primera, la multiplicidad de aplicaciones que, aunque tardíamente, llegan a producirse apoyadas tanto en la dirección ordinamental como institucional, si bien primando ésta sobre aquélla al principio, para, luego de la traducción de L'ordinamento giuridico de Santi Romano en el año 1963, encontrar un aparente punto de equilibrio que en realidad obedece a la trivialización de los postulados romanianos más que a su estricta y plena aceptación. Segunda, la diversa interpretación ideológica y adaptabilidad al ambiente político de cada momento (década de los 40 y de los 60 , principalmente) que su cultivo muestra en disciplinas de contenido jurídico-político, aunque debiéndose subrayar cierta propensión hacia su empleo no en favor de posiciones liberal-democráticas. Finalmente, tercera, la prácticamente nula incidencia sobre la actual doctrina iuspublicista, salvo elaboraciones que apenas conservan algo más que consonancias nominales. Este estudio ha servido de base a otro más amplio, que abarca también disciplinas de Derecho Privado y las direcciones institucional y ordinamental en la Filosofía Jurídica española y que integra el tercer capítulo de $L a$

\section{CALVO GONZÁLEZ, José.}

\section{Presupuestos del fenómeno jurídico en la crítica marxista del derecho.}

Anuario de Filosofía del Derecho, Madrid, n. o 2, 1985, págs. 337-358.

El trabajo plantea fundamentalmente un cúmulo de preocupaciones metodológicas que arrancan con una advertencia sobre la necesaria diferenciación -que evite interpretaciones extensivas, falsas identificaciones conclusivas o desdoblamientos infundados- entre fuentes relativas a la teoría del Estado y propiamente referibles a una más o menos precisa teoría marxista del Derecho. A ello se añade la recomendación, para el estudio de las categorías jurídicas, del empleo de los principios metodológicos contenidos en el Prólogo a la Contribución a la crítica de la economía política, de manera que sea posible reflexionar sobre las formas del fenómeno jurídico en su configuración más abstracta y pura, pasando luego, por complicación, a la concreción histórica donde, ciertamente, se imbrican muy de cerca y hasta se asimilan Derecho, Derecho del Estado y Derecho del Estado burgués. Persiguiendo esta sistematización teórica se delimitan tres presupuestos (presupuesto ideológico, revolucionario y antropológico) de los que resultan tres categorías específicas (ideología, revolución y hombre) a través de las que el fenómeno jurídico encuentra el perfilamiento y continente más representativo entre los aspectos de carácter crítico que han sido enunciados por la crítica marxista del Derecho. Finalmente, en la relación posible «Filosofía del Derecho-Marxismo» se opta por la técnica del método comparativo entre la pretendida o eventual teoría marxista del Derecho y las más importantes teorías de la ciencia jurídica contemporánea. 
la confusión entre el fundamento de la protección que los ordenamientos jurídicos otorgan a ciertas relaciones sociales y la naturaleza de las instituciones jurídicas en que se albergan, o lo que es igual, la distinción entre el por qué de la ordenación y protección jurídica y la razón normativa de las instituciones y expresiones técnicas de ordenación jurídica.

institución Jurídica. Interpretación y análisis del lenguaje jurídico (Publics. de la Universidad de Málaga, 1986, $142 \mathrm{pp}$.). 


\section{CAPELLA $、 J u a n$ Ramón.}

El trabajo como dato prejurídico.

Doxał Alicante, n. ${ }^{\circ}$ 2, 1985, págs. 117-128.

Este artículo -extraído por el Consejo de Redacción de Doxa del libro de J. R. Capella|Dos lecciones de Introducción al Derecho- toma como punto de partida la noción de trabajo y algunos rasgos fundamentales de éste. El trabajo humano, relación o intercambio necesario del hombre con la naturaleza, es social, indirecto (por la pluralidad de instrumentos que utiliza), y no sólo produce cosas, sino también ideas, que son medios de producción de importancia difícilmente exagerable.

Seguidamente se analizan los aspectos de la división social del trabajo y el grado de influencia que han tenido en ella las causas naturales (que son las menos poderosas), y las técnicas de producción. La conclusión es considerar al aspecto económico-político como la causación más poderosa, pues configura el aspecto clasista de la división del trabajo.

Hablando del origen del Derecho, explica Capellal que en las comunidades primitivas no había poder político ni jurídico: sólo mitos y una moralidad positiva de gran fuerza ideológica que ordenaba la sociedad de un modo más simple que el Derecho.

El poder político y jurídico nacen en formas de organización social más complejas, en concreto con la práctica de la agricultura masiva en Egipto y Mesopotamia. Allí aparece el conflicto social, y para anularlo surge una fuerza centralizadora: el poder político, violencia institucionada que garantiza la rẹproducción del conjunto social. Este Estado no sólo tiene una función represiva contra los intentos de emancipación de las comunidades subordinadas, sino también una función civilizadora, que hizo de aquella fuerza militar dirigente un poder político y jurídico.

(M. J. M. C.)

CAPELLA, Juan Ramón.

Entre sueños.

Ed」 Icaria, Barcelona, 1985, 199 págs.

Bajo el titulo de Entre sueños el autor reune los siguientes trabajos de filosofía política escritos a lo largo aproximadamente de una década (desde 1974): Fragmentos de un discurso libertario; Cien años después de Gotha; Sobre la burocratización del mundo; La mirada de Marx sobre el Leviathan't El lobo que viene lo sobre la fascistización silenciosa); Apuntes de principio y método para la reflexión política en el fin dell milenio. A pesar de algunos cambios de énfasis explicables por los distintos momentos en que fueron redactados los trabajos que lo integran, el libro es bastante unitario, en cuanto expresión de un pensamiento político cuyo núcleo ha permanecido más o menos inalterado. Concretamente, la filosofía política de Capellal que se expresa en este libro puede caracterizarse a partir de los tres siguientes rasgos.

El primero es la procedencia marxista del entramado teórico que vertebral su filosofía política así como de la ideal practica que guía todo su discurso: la emancipación humana, entendida como tarea que desemboca socialmente en el comunismo y políticamente en la acracia. Sin embargo』mientras que la «idealidad fundamental» de Marx no es nunca puesta en cuestión por Capella, no ocurre lo mismo con el aparato teórico del marxismo, con respecto al cual el autor va mostrando a lo largo del libro una distancia cada vez mayor que no le impide, en todo caso, seguir situandose dentro de la tradición de pensamiento marxista.

El segundo es su crítica radical al sistema político representativo. En su opinión, la representación política presupone necesariamente desigualdades sociales concretas que tratan de compensarse (precariamente) con la concesión de una igualdad política abstracta; en definitiva, el sistema político representativo presupone el capitalismo.

\section{CARPINTEROBENÍTEZ, Francisco.}

Voluntarismo y contractualismo: una visión sucinta de la escuela del Derecho natural.

Persona y Derecho, n. ${ }^{\circ}$ 13, 1985, págs. 61-109]

Este artículo comienza haciendo referencia a los profundos cambios que sufrió la ciencia jurídica en el siglo XVI y que culminaron con el nacimiento de una nueva disciplina: el Ius Naturale. Este respondía a presupuestos antropológicos y metodológicos que eran distintos de los del iusnaturalismo medieval. Todos estos autores (Grocio, Hobbes, Pufendorf, Vázquez de Menchaca, Wolff, etc.), participan de lo que «podríamos llamar principio militarista» que conduce a un proceso de análisis reconstructivo de la sociedad tratando de fundamentar racionalmente sus puntos de partida y las conclusiones alcanzadas. En este proceso reconstructivo la dicotomía estado de naturaleza/sociedad civil es la pieza clave, puesto que todos ellos recurren a ella; sin embargo, hay diferencias importantes entre ellos al explicar los moviles de la transición de un estado a otro (que se opera a través del pacto o contrato) y los fines de ese proceso; Váquez de Menchaca, por ejemplo, sitúa como finalidad del pacto la defensa de los «iura naturalian; lo mismo sucede con Pufendorf. Hobbes, por el contrario, sitúa como finalidad última del contrato, por medio del cual surge la sociedad civil y el Estado, la seguridad de los ciudadanos. Otro rasgo común del pensamiento jurídico de este periodo es la sobrevaloración de la leyl positiva (generalmente entendida como mandato del poder), preparando así el camino para la reducción del Derecho a la ley que triunfará de manera definitiva con la revolución francesa. Concluye el articulo con un último epígrafe dedicado a Rousseau. En él se analizan los problemas derivados de la distinción entre «volonté générale» y «volonté de tous». 
Finalmente, el tercero de los rasgos lo constituye la consciencia de que estamos inmersos en una profunda crisis civilizatoria que condiciona toda la reflexión y la práctica política y ética. Algunas de las características de dicha crisis civilizatoria serían las siguientes: 1) La amenaza ecológica y nuclear que hace que la crisis actual sea cualitativamente diferente de todas las anteriores. 2) El antagonismo existente entre el progreso tecnológico y el progreso social. 3) La «fascistización silenciosa» que caracteriza al Estado burgués de final de siglo que adopta rasgos híbridos permanentes: rasgos de sistema representativo y rasgos fascistas encubiertos; entre estos últimos se encuentran: la estatalización y burocratización interna de los partidos políticos, el auge de la «razón de Estado» y del «secreto de Estado», o la simbiosis entre los Estados y el capital transnacional a través de «la industria de la manipulación de las consciencias». 
La justificación ética del Derecho como tarea prioritaria de la filosofía política. Una discusión desde John Rawls.

Doxa, Alicante, n. ${ }^{\circ}$ 2, 1985, págs. 129-144.

Como revela el significativo título escogido por la autora para plasmar la idea central sobre la que gravita su exposición, Adela Cortina pretende reivindicar la importancia y prioridad de atención que en el marco de la filosofía política tiene, a su juicio, el análisis de la fundamentación ética del Derecho, como condición sine qua non para consolidar las sociedades democráticas; tal reflexión se orienta a fijar los criterios de legitimidad critica o validez, estimando la autora de especial interés la propuesta realizada en este sentido por John Rawls. Apunta el rótulo «iusnaturalismo procedimental» para caracterizar la justificación rawlsiana del Derecho, que se cimenta sobre una filosofía moral sistemática, deontológica, no teleológica e inspirada en el «constructivismo kantiano», encaminada a descubrir la objetividad moral. A grandes rasgos, según señala, la fundamentación ética del Derecho delineada por Rawls descansa en la autonomía real del hombre -basada en el reconocimiento de su «carácter autolegislador»- ejercida en condiciones ideales que garantizan la justicia de la elección y que expresan la unidad de la racionalidad práctica en su doble función, empírica -lo «racional»- y pura -lo «razonable»-. Como remate a su estudio la autora pone en tela de juicio el presunto carácter normativo de los principios rawlsianos de la justicia, propugnando una «tercera vía», que conjugue trascendentalismo e historia, sensible al carácter evolutivo de la conciencia moral-jurídica y al «valor normativo de las condiciones insuprimibles del sentido de los juicios».

\section{CORTINA ORTS, Adela.}

Razón comunicativa y responsabilidad solidaria. (Epílogo de K. O. Apel).

Ed. Sígueme, Salamanca, 1985, 276 págs.

Este libro trata de analizar con detalle las propuestas del filósofo alemán K. O. Apel tendentes a buscar una «fundamentación filosófica última» de los principios prácticos.

Con especial cuidado se expone ya en la Introducción y en el capítulo primero el significado de la expresión «fundamentación filosófica última» de los principios morales utilizada por Apel. Fundamentación última equivale a "dar razón» sobre las valoraciones y opciones morales; fundamentación última es sinónimo de argumentar racionalmente y la argumentación racional implica unos presupuestos trascendentales que la hacen posible, de ahí que la «fundamentación última» suponga desvelar los presupuestos trascendentales que hacen posible todo proceso argumentativo. Este problema se plantea en la polémica de Apel con el «racionalismo crítico» de K. Popper y H. Albert para los cuales la fundamentación última es sustituida por la «decisión última». El otro blanco de Apel es el «solipsismo metódico», que presupone que los individuos pueden actuar con sentido y pensar válidamente al margen de la comunidad; la consecuencia última de todo este planteamiento es que la razón «estratégico-monologica» no tiene reparo en utilizar a los demás hombres como medios. A partir de aquí la autora analiza las diferencias que separan a Apel de Rawls y rastrea las fuentes del pensamiento apeliano: Kant, Peirce y el segundo Wittgenstein.

El factum rationis kantiano no es para Apel un «yo» trascendental sino que, a partir de la reflexión sobre el lenguaje, Apel entiende que es el lenguaje el que marca los límites del mundo. La reflexión trascendental es proyectada sobre un hecho: el hecho lingüístico, el factum rationis kantiano es para Apel la argumentación. Esta es un hecho irrebasable, «quien desee eliminarla racionalmente se verá obligado a aducir argumentos».

\section{CORTINA ORTS, Adela.}

\section{Rehabilitación de la razón práctica desde la ética de la ciencia.}

Sistema, Madrid, n. ${ }^{\circ}$ 67, julio de 1985, págs. 97-108.

El artículo parte de la constatación del siguiente hecho: cada día es más profundo y más amplio el abismo que separa a la razón teórica de la razón práctica, al ser y al debe-ser. El resultado es un concepto de objetividad y racionalidad cercenado; la ciencia patrimonializa para sí en exclusiva la idea de objetividad. Este planteamiento teórico tiene inmediatas consecuencias prácticas: la vida pública aparece regida exclusivamente por la razón cientifico-técnica (instrumental y estratégica) y la vida privada por el pluralismo axiológico de decisiones subjetivas. Este hiato hace imposible el logro de un consenso intersubjetivo que legitime las decisiones individuales. Frente a esta situación de escisión se ha venido gestando en los últimos años todo un movimiento de «rehabilitación de la razón práctica». Este artículo estudia las consecuencias éticas y políticas de la obra de Ch. Peirce y el uso que hacen de ella autores como K. O. Apel en su intento de fundamentar racional e intersubjetivamente la ética.

Del análisis de la obra de Peirce, extrae la autora las siguientes conclusiones: . 1) no puede identificarse el sujeto de la ciencia con un sujeto individual, pues su finitud le impide el conocimiento de la totalidad de lo real; el sujeto de la ciencia pasará a ser entonces una comunidad rẹal de investigadores que, por tanto, sólo pueden lograr proposiciones fácticamente consensuadas y por ello revisables; 2) la propuesta de Peirce reclama, además de un mundo real y una comunidad de interpretes reales, una comunidad ideal que actuando al modo de metainstitución garantice la objetividad y la verdad fácticamente consensuada.

De otra parte, la autora pone de relieve la clara dimensión ética del trabajo científico que se manifiesta en la siguiente paradoja: de una parte, el investigador ha ingresado en el proceso científíco porque está interesado 
De Peirce extrae Apel las consecuencias últimas de su planteamiento: es imposible el conocimiento científico al margen de una comunidad de argumentación que fija el valor de las ideas e hipótesis.

El capítulo segundo, Fundamentación pragmático-trascendental de una ética argumentativa, comienza preguntándose si es posible una racionalidad no científica. Este tema es uno de los más polémicos no sólo en la teoría de la ciencia sino también en el de la metaética. Para Apel el terreno de lo objetivo no se limita al conocimiento científico sino que se extiende también a las normas; este planteamiento se apoya en dos premisas normativas relativas al conocimiento práctico: $\left.1{ }^{a}\right)$ la intersubjetividad de las normas descansará en la corrección del razonamiento práctico, 2..$^{a}$ ) pero las primeras premisas normativas, para ser racionales, no pueden surgir de consensos fácticos sino que necesitan ser filosóficamente fundamentadas. Todo lo anterior nos conduce de nuevo al proceso de argumentación. No sólo los científicos argumentan para defender sus hipótesis sino que cualquier hombre debe argumentar, a la hora de resolver los conflictos intersubjetivos, si se pretende que la solución a tales conflictos sea racional. A continuación, la autora, estudia los supuestos de la "pragmática trascendental del lenguaje», analizando las contribuciones de Searle y Habermas. Aquí el trabajo de Searle relativo a los «actos de habla» es reinterpretado por Apel desde una perspectiva «trascendental»; desde esta perspectiva aparecen unos elementos esenciales, a priori, e ineliminables que hacen posible la comunicación y el entendimiento mutuo. La pragmática trascendental, realiza, en este sentido, una reconstrucción de las reglas universales implícitas en los actos de habla, en tanto que trata de explicitar las condiciones de posibilidad de toda argumentación racional.

En el tercer y último capítulo, «Ética y Política», se explican las razones, que no decisiones, que avalan la adhesión a un sistema político democrático, conclusión lógica de todo el planteamiento precedente.

Concluye el libro con un Epílogo del propio K. O. Apel: «¿Límites de una ética discursiva?» En él se desarrollan con detalle los problemas relativos a la «fundamentación filosófica» como visión opuesta al «decisionismo», fundamentación basada en las cuatro pretensiones de validez (verdad, veracidad, corrección y sentido) del discurso argumentativo que se presentan como irrebasables.

en hallar la verdad, de otra, el científico es consciente de que su inteligencia es finita y, en consecuencia, lo cognoscible le desborda. ¿Cómo disolver esta paradoja?

Si el científico quiere ser fiel a su profesión tiene que asumir una actitud moral movido por el interés hacia la verdad, que es uno de los compromisos morales más importantes. Esto conlleva, a juicio de la autora, a) «una actitud de autorenuncia frente a los propios intereses y convicciones» que pueden distorsionar el camino hacia la verdad, b) «un reconocimiento del derecho de los miembros de la comunidad real de investigadores a exponer sus hallazgos y de la obligación ante ellos de justificar los propios descubrimientos»; c) «una actitud de esperanza en el consenso definitivo» garante de los consensos fácticos. El investigador en suma, «se ve obligado a olvidar todo egoísmo y aceptar las claves fundamentales del socialismo lógico: autorrenuncia, reconocimiento, compromiso moral y esperanza». 
COTTA, Sergio.

Perfil de una ontofenomenología del derecho. (Trad. de Andres Ollero).

Anales de la Cátedra Francisco Suárez, Granada, n. ${ }^{\circ} 25$, 1985, págs. 29-35.

El autor propone una perspectiva de la filosofía del Derecho que denomina «ontofenomenología del Derecho», expresión que pone de relieve sus bases teóricas y metodológicas (referencia al problema ontologico y al método de análisis fenomenológico en la línea abierta por Husserl y Heidegger). La integración de estos dos elementos responde no a un empeño sincretista, sino a la convicción del autor de que de este modo puede darse una solución satisfactoria al problema del fundamento del Derecho. A partir de ahí, el autor polemiza con la teoría clásica, que fundamenta al Derecho en la naturaleza, y con las teorías jurídicas contemporáneas, que no ofrecen una justificación adecuada de algunos aspectos esenciales de la experiencia jurídica.

En relación con estas últimas, el autor, tras afirmar la naturaleza cognoscitiva de la filosofía del Derecho, toma como arquetípicas las teorías de Kelsen, Hart y Rọs que, a pesar de sus diferencias (formalismo versus realismo) tienen en común caracteres esenciales: el principal es que se basan sobre el Derecho empírico, pero observado sólo en el nivel fenoménico, por lo que la realidad del Derecho resulta reducida a su apariencia, sin indagar si la apariencia no es sino la manifestación de algo distinto. La insuficiencia de estas teorías radica en que situan como característica esencial del Derecho a la coercitividad, que, a su vez, es la que determina la obligatoriedad de las prescripciones jurídicas; mientras que, para el autor, la coercitividad determina la obediencia y no necesariamente la obligatoriedad. Ello le lleva a concluir que, en estas teorías, el problema de la obligatoriedad del Derecho queda sin solución.

Esta insuficiencia de las consideraciones meramente fenoménicas del Derecho «empuja hacia la búsqueda del

CRUZ CRUZ, Juan.

\section{Derecho e Historia en el pensamiento de Kant. El proyecto final de uno paz democrática.}

Persona y Derecho, Pamplona, n. ${ }^{\circ} 13,1985$, págs 197-261.

Este artículo analiza la tesis kantiana de que el fin de la historia consiste en alcanzar el reinado de la paz perpetua, articulando una estructura política que haga posible tal fin. El autor comienza examinando la distinción kantiana entre fines naturales y sobrenaturales; el único fin natural del hombre admitido por Kant es su realización y la realización de la sociedad a través del imperativo categórico, esto es, por obediencia a la ley que uno mismo se da. Hay que destacar igualmente la distinción kantiana entre «fe eclesiástica» (fe vivida en el culto y basada en la revelación) y «fe religiosa» o fe de la razón, sin culto y «equivalente a la moralidad». A continuación se estudia la interpretación kantiana de la filosofía de la historia de San Agustín.

La filosofía de la historia de Kant es estudiada a la luz de dos categorías contrapuestas en el pensamiento kantiano: naturaleza y libertad. En la naturaleza reina la necesidad; en las relaciones intersubjetivas domina la libertad; sin embargo, en la obra kantiana se afirma que habrá un sometimiento de la naturaleza a la libertad a través de la historia pues «no sólo están sometidos a las leyes universales de la naturaleza los fenómenos físicos, sino también las acciones humanas voluntarias. De ahí que la historia deba narrar esas manifestaciones humanas, para ofrecer la corriente regular de dirección uniforme de la especie humana». Esto significa reconocer que Kant asume un planteamiento finalista de la historia en la que Dios es la garantía de la concordancia de los fines naturales con los fines morales. Kant, al igual que la tradición que le precede, admite la existencia de un estado de naturaleza y un posterior estado civil; el tránsito de uno a otro se articula a través de un pacto que da lugar a un estado civil donde se ceden al soberano el mero ejercicio, que no la titularidad, de los derechos

\section{DÍAZ, Elías.}

\section{La justificación de la democracia.}

Sistema, Madrid, n. ${ }^{\circ}$ 66, Mayo 1985, págs. 3-23.

Este artículo constituye una prolongación y complementación del libro De la maldad estatal y la soberanía popular, publicado en 1984. Dos núcleos de problemas constituyen su eje: 1) El análisis de la legitimidad democrática vista desde la perspectiva de la teoría de la justicia (la teoría de la justicia, en cuanto parte esencia) de la filosofía jurídico-política, «es una teoría crítica de los sistemas de legitimidad») en profunda conexión con esto se encuentra el problema de la justificación de la obediencia al Derecho en los sistemas democráticos, con respecto al cual el autor mantiene la misma tesis que en el libro anteriormente citado, es decir, la de que existe un fundamento ético para obedecer al Derecho, especialmente, en los sistemas políticos democráticos. 2) El otro núcleo del artículo lo constituye el análisis del proceso de acumulación capitalista que se opera en países con un sistema político democrático que, por un lado, han de hacer posible esa acumulación, y, por otro, han de legitimar el sistema político no ante una clase sino ante el conjunto de los ciudadanos. Dentro de este mismo apartado, se trata el problema de la eventual existencia de una relación necesaria entre los sistemas políticos democráticos y el modo de producción capitalista. Para el autor, esta relación no es necesaria; de esta manera rechaza, igualmente, las críticas de la izquierda, que son personalizadas en C. Offe, como las liberales y conservadoras, para las que la democracia únicamente tiene sentido, en la medida en que se refleje y proteja los valores e intereses de un determinado modelo de sociedad «definido de modo necesario y esencial por el control y/o apropiación privada de los medios de producción». Frente a estas dos alternativas, el autor se muestra partidario de utilizar coordinadamente las instituciones democráticas y los movimientos de base que, junto con 
sentido del fenómeno jurídico, utilizando la lección fenomenológica de Husserl». Así, sostiene que la regla de comportamiento es el signo del que partir para captar el sentido de la experiencia jurídica. La regla establece una relación objetiva entre sujetos y la regla jurídica «es potencialmente universal o universalizable». De ahí es posible «reconducir el actuar humano -diversificado y contradictorio en el plano empírico- a la unidad de un único mundo (del actuar) dotado de sentido»; y el sentido del Derecho será la coexistencia universal. «A su vez, este sentido presupone el dato ontológico de la paridad estructural (y no meramente fenoménica) de los hombres. Esta paridad es la que da origen a la regla jurídica en su forma específica».

(J. A. R.)

naturales. Siguiendo esta misma línea argumentativa, para Kant, el Estado no es otra cosa que la plasmación de la exigencia de que las libertades sean tuteladas incondicionalmente. Poco a poco, se va esbozando en el pensamiento de Kant la idea de un Estado perfecto como meta de la historia, este esbozo aparece con mayor claridad en obras como «Idea de una historia universal desde un punto de vista cosmopolita», «¿qué es la Ilustración?» $\mathrm{y}$ «La paz perpetua», entre otras.

(L. A. G. P.)

otros elementos, contribuirán a sentar las bases de un socialismo democrático. Todo ello conduce a concluir al autor de la siguiente manera: «Que esta democracia y este socialismo democrático no existan hoy, o que no exista en la medida en que muchos lo desearían, en modo alguno supone prueba en contrario de su futura fáctica posibilidad y mucho menos, claro está, refutación válida de su ética racionalidad».

(F. L. R.) 
Giole Solari, entre la crisis de la metodología jurídica racionalista y la génesis de la ideología social en el Derecho.

Anuario de Filosofía del Derecho, Madrid, n. ${ }^{\circ}$ 2, 1985, págs. 359-392.

Este artículo constituye una aproximación a la obra de Gioele Solari dentro del pensamiento iustifilosófíco. La forma de afrontar el tema -en palabras de los autores- consiste «en tomar en consideración el núcleo de la ideología jurídica desde su nacimiento en el siglo XVIII, y de manera sistemática con el inicio de las codificaciones a partir de Napoleón, hasta el último tercio del siglo XIX, época en la que tienen lugar los primeros intentos de recomposición de las ideas filosóficas en base a los sistemas existentes, y el paso, dentro de la ciencia jurídica de una jurisprudencia conceptual a una jurisprudencia, primero pragmática, y luego abiertamente centrada en los intereses. Todo ello en el marco de la aparición, más o menos difusa, del movimiento social de los trabajadores y sus diversos intentos de entrar en relación política inmediata con el proceso capitalista de producción». Asimismo, los autores consideran que el trabajo les brinda una «oportunidad para llamar la atención sobre el uso que el jurista teórico hace de los mecanismos lógicos y conceptuales acuñados por el conocimiento científico y, por lo tanto, de las interpretaciones lógico-metodológicas (en clave política) que nos ofrecen para desentrañar el misterio propio de la teoría y de la especulación jurídica desde su genética histórico-ideológica: misterio que se manifiesta en la ambigüedad lógica que ha supuesto siempre para el conocimiento de 'To jurídico' no poder mediar y aprehender en su significación histórico-concreta la socialidad originaria y propia de la relación de trabajo de los hombres (libres e independientes) entre sí, y en conexión con las subjetividades de la circulación y, más tarde, de la productividad, que van a ser las autenticas conceptualizaciones significadoras de la sociedad de los individuos dentro del proceso global del trabajo».

\section{Estudios de Filosofía del Derecho y Ciencia Jurídica en Memoria y Homenaje al Catedrático Don Luis Legaz} y Lacambra (1906-1980). T. II.

Ed. Centro de Estudios Constitucionales y Facultad de Derecho de la Universidad Complutense (Colección Estudios Políticos, n. ${ }^{\circ}$ 11), Madrid, 1985, 892 págs.

Este segundo tomo contiene los siguientes artículos: L. F. Coelho, Una teoría crítica del Derecho; J. J. Gil Cremades, El pensamiento jurídico en la España de la Restauración; N. Martínez Morán. Titularidad y ejercicio del poder en Francisco Suárez; A. Ollero, Hobbes y la interpretación del Derecho; J. L. de Orella, Marsilio de Pádua. Encuadre histórico de su aportación ideológica; E. Pattaro, Sul normativismo di un realista: La critica hägerströmiana del volontarismo giuridico e il concetto di dirito valido; W. Paul, Cambio social y transformacion de la filosofía del Derecho; A. Peczenik, Operational Approach to the Theory of Law; I. Peidró Pastor, La amistad como factor de convivencia política; A. E. Pérez Luño, Notas sobre la filosofía jurídico-política de Juan Ginés de Sepúlveda; A. Poch, Nexos hispánicos de Benito Espinosa; P. N. Popov, Uber die würde des menschen im lichte der verfossung der volksrepublik bulgarien; F. Puy, Algunos tópicos actuales sobre derechos humanos; A. M. Quintas, Algunas reflexiones epistemológicas a proposito del análisis filosófico de la politicidad; J. T. Raga, Ideología, sistema económico y derecho natural; M. Reale, Situaçôes subjetivos e direito subjetivo; L. Recaséns, Aplicación práctica de la estimativa jurídica a los problemas del presente; L. Reis, On Law and Reality; G. Robles, La decisión en el Derecho y la tópica jurídica; L. Rodríguez-Arias, Las estructuras y los modelos en el Derecho; M. Rodríguez Molinero, Sobre los métodos filosóficos y su aplicación al Derecho; J. M. Rodríguez Paniagua, Derecho y usos sociales. El Derecho como uso social «fuerte»; J. Rossiñol, Iniciación a un análisis lógico-matemático de los relaciones entre caridad y justicia; M. Rotondi, Considerazioni in «fatto» e in «diritto»; H. Reyffel, Rechtsphilosophie als Philosophie des Politischen-Fortführung un Wand lung einer Klassischen Konzeption; A. Salemi, Fasti e nefasti della democrazia; A. Sánchez de la To-

\section{FARRELL, Martín D.}

Dworkin y el utilitarismo: algunas inconsistencias.

Doxa, Alicante, n. ${ }^{\circ} 2$, 1985, págs. 187-195.

En este comentario a la obra de Dworkin contra el utilitarismo, Farrell parte de fragmentos de varios de sus libros para poner de relieve su falta de consistencia.

Del libro de Dworkin «Taking Rights Seriously», Farrell extrae lo que él llama la «Versión 1» de Dworkin sobre el utilitarismo, donde dice, adecuadamente, que para éste los deseos de un individuo son tan importantes como los de otro, habiendo de tener en cuenta tanto las preferencias personales como las externas de los individuos, (porque entre otras causas, es imposible separarlas). Farrell critica la teoría alternativa que propone Dworkin: «El concepto de un derecho político individual (...) es la respuesta a los defectos filosóficos de un utilitarismo que computa las preferencias externas y a la imposibilidad práctica de un utilitarismo que no lo hace». En ella señala dos defectos, uno apuntado por Ten (la cuestión no está en excluir las preferencias externas, sino en el contenido de las preferencias externas que se excluyen) y otro por Hart (sobre la igual consideración y respeto). Pero mientras ésta era una descripción correcta del utilitarismo, mostrando sus virtudes y defectos, en una obra posterior Dworkin da una segunda versión que es inconsistente con la primera (según esta segunda versión, el utilitarista debe distinguir entre las preferencias que deben ser tomadas en cuenta; parece, por tanto, no haber dificultad en separar las preferencias personales de las que no lo son) e inadecuada (pues se excede en la atribución de virtudes). Según Farrell, estas críticas a Dworkin pueden efectuarse a pesar de una sutil distinción que hace Dworkin entre dos distintas motivaciones básicas para optar por un punto de vista utilitarista: la idea de que el placer es bueno, lo que conduciría a la adopción del utilitarismo clásico, y la creencia en un principio 
rre, El «nomos» y sus enemigos; J. D. Sánchez Estop, La imaginación en el pensamiento filosófico de Baruj de Espinosa (De la pasividad al orden constitutivo); J. A. Sardina-Páramo, Algunos consideraciones sobre la certeza del Derecho y el ordenamiento jurídico español; B. Scucces Muccio, La certeza giuridica nella «Scienza della legislazione» di Gaetano Filangieri; H. Schambeck, Geltung und Autorität; C. Schefold, Die Gleichheit und Ungleichheit der Freiheit; E. Serrano, Libertad y Libertades; J. T. Villarroya, La dirección dogmática en el Derecho público; P. Trappe, Soziale Norm, Normalität und Wirklichkeit; A. Truyol Serra, Nota sobre la versión expurgada de la Politica de Lipsio; Arthur-Fridolin Utz, Soziolethische Uberlegungen úber die Familie; J. Vallet de Goytisolo, Dos conferencias en memoria del prof. Elías de Tejada; C. Varga, Law and the Historicity of its Formal Relatedness: Historicity in Law and its Objectification and Approach as a System; J. J. M. Van der Ven, Permanente de la Philosophie du Droit de Saint Thomas d'Aquin; T. Viehweg, Antirhetorische und Rhetorische Kontrolle Rechtlicher Argumentationem; C. de Villamor, La contribución del pensamiento problemático a la ciencia jurídica; M. Villey, Questions sur l'ontologie d'Aristot et la langue du Droit Romain.

(J. A. R.)

igualitario abstracto que conduciría a adoptar una posición utilitarista compatible con la afirmación del postulado de igual consideración y respeto.

(M. J. M. C.) 
FERNÁNDEZ BUEY, Francisco.

Marxismo en España.

Sistema, Madrid, n. ${ }^{\circ}$ 66. Mayo de 1985, págs 25-42.

El tema de este artículo es el problema de la recepción de la obra de Marx en España: ¿cómo y en qué circunstancias se produce la recepción del pensamiento marxianol en España?, concretamente, la pregunta inicial del autor es la siguiente: ¿por qué hay una escasa difusión de la obra de Marx en nuestro país en el último tercio del siglo XIX? Ni el retraso industrial español, ni la apelación a ahistóricas esencias patrias o de idiosincrasia (espontaneismo, individualismo, desconfianza ante la ciencia, etc.), suministran una información satisfactoria de este fenómeno migratorio en el último tercio del siglo XIX, la decepción de los trabajadores ante la democracia liberal, a la inconstitucionalidad de la A.I.T. los que permiten construir hipótesis aceptables sobre laatipici-1 dad de este proceso de recepción de la obra de Marx.

El autor se preocupa, en primer lugar por la contribución de Jaime Vera a la difusión y divulgación de las ideas de Marx en el último tercio del siglo pasado; la aportación de Jaime Vera, analizada detalladamente, muestra como éste tenía una comprensión muy peculiar de la obra de Marx que, por un lado, le conducía a un economicismol mecanicista y, por otro, a combatir el papel de los científicos e intelectuales en la sociedad capitalista. En segundo lugar, el autor estudia el problema de la recepción del marxismo en el primer tercio del siglo XX (hasta la guerra civil). Se trata de la época de la división del movimiento obrero, pero también de la de mayor volumen de traducciones de las obras de Marx y Engels en España. Valentín Hernández, Andreu Nin」Julián Besteiro, Luis Araquistain y Wenceslao Roces, junto con las revistas Comunismo y Leviatán, son los cauces de introducción, divulgación y debate de la obra de Marx en este período.

\section{FERNÁNDEZ DE CASADEVANTE ROMANIJ Carlos.}

\section{Aproximaciones sobre el desarme y la no-violencia.}

Anuario de Filosofía del Derecho, Madrid, n. ${ }^{\circ}$ 2, 1985, págs. 185-194.

El desiderátum contenido en el Preámbulo de la Carta de las Naciones Unidas de 1945 es el reflejo de una voluntad de los Estados miembros que, a la vista de la situación internacional actual, ha devenido falaz y desviada. Del firme propósito de aunar los esfuerzos para realizar la paz que se contenía en aquel texto, se ha pasado a la primacía de los intereses nacionales sobre los generales ya un despilfarro económico en armamento irreconciliable en absoluto con los principios de la Carta.

Señala el autor que la acumulación de armas, y en particular armas nucleares, constituye una amenaza -que no una protección- para la humanidad. El desarme se ha convertido en un objetivo obligado para la Comunidad de Estados, pero la consecución de la paz necesita ademas, de la potenciación de la solidaridad internacio-t nal y del arbitraje de unos medios que frenen las injusticias actuales, para todo lo cual se propone la vía de la celebración -bajo una verdadera voluntad negociadora- de acuerdos internacionales sustantivos. Por otro lado, la tarea de construcción de la paz cuenta como factor esencial, en el plano individual, con la defensa de los derechos humanos (como proclama el principio VII del Acta Final de Helsinki). Es aquí donde afluye el derecho a la objeción de conciencia «en cuanto a concienciación de la persona humana que rechaza el uso de la violencia en la resolución de las controversias no sólo nacionales, sino tạmbién internacionales». Con conocimiento del verdadero significado de los derechos fundamentales del individuo, han sido las Organizaciones Internacionales (Naciones Unidas y Consejo de Europa) las primeras en proclamar este derecho a través de textos como el Pacto Internacional de Derechos Civiles y Políticos, la Declaración Universal de losDere-

\section{GALINDO AYUDA, Fernando.}

\section{Democracia, razón y derecho.}

Anuario de Filosofía del Derecho, Madrid, n. 20, 1985, págs. 317-336.

Hablar con «propiedad» sobre derecho positivo, es una actividad cada vez más difícil. Para ello se precisa poseen innumerables conocimientos, no sólo sobre la materia regulada, sino, especialmente, sobre el propio «concepto» de derecho, además de sobre las «características» de su «actuación». No hay duda de que ello está ligado a las que se han considerado son las notas típicas de la sociedad y el Estado de los países «occidentales» en la actualidad: a todas ellas se les comprende cuando sa las quiere conocer, usualmente, tras el término complejidad. Con estọ se limita la puesta en práctica de varios mandatos constitucionales. Muy en especial el principio de la participación de los ciudadanos en los «asuntos públicos». También, por ejemplo, el del «igual acceso a la administración de justicia». En relación a todos ellos, el más general de la igualdad ante la ley. En definitiva, se infringe la exigencia de llevar a efecto el término «democracia», entendiendo a éste en su más amplio significado. Nadie pone en duda que la dificultad de llevar a cabo estos ideales tiene que ver con el hecho de que el derecho positivo ha de ser complejo, si a su través se quiere regular a nuestra sociedad. Sólo que el problema es el trato suministrado a las «leyes» por quienes tienen la obligación de sistematizarlas: aquéllos que reflexionan por «profesión»l sobre el derecho. Lo cual, obviamente, significa entorpecer la vinculación democracia-razón-derecho que está colocada, como antes indicábamos, aunque sea tácitamente, en el frontispicio de los sistemas jurídicos occidentales desde que las revoluciones liberales alcanzaron reconocimiento jurídico.

De cómo las actitudes «reflexivas» ante el derecho incrementan el alejamiento del derecho positivo de losciudadanos, se da cuenta en el artículo, al exponer quiénes se aproximan al derecho y cuál es su «modo» (método) de acercamiento, al mismo tiempo que se contesta a lo siguiente. Sin dejar de dar soluciones jurídicas adecuadas 
Con posterioridad a la guerra civil, y teniendo en cuenta el contexto político de esos momentos, el autor dedica especial atención a la obra y personalidad de Manuel Sacristán, examinando su contribución a la recepción no sólo del marxismo a secas, sino también de las distintas «escuelas» marxistas y su aportación a materias tan importanta como la lógica, la teoría de la ciencia o la crítica filosófica.

Concluye el articulo con unas breves reflexiones sobre la reciente historia del marxismo en España, condicionada por la coyuntura política originada después de 1977.

(F. L. R.)

chos Humanos, la Convención Europea para la protección de los Derechos del Hombre y Libertades Fundamentales y la Resolución 337 de la Asamblea Consultiva del Consejo de Europa.

En el marco del continente europeo, cuatro son los Estados que reconocen constitucionalmente el derecho a la objeción de conciencia, a saber: Alemania, Holanda, Portugal y España, desarrollándolo posteriormente por vía de ley. En lo que respecta a este último país, este derecho comienza a ser declarado con un decreto del año 1976, que admite la negativa a prestar el servicio militar cuando la objeción esté basada en motivos de carácter religioso, y sólo en ese caso. Hasta esa fecha el Código de Justicia militar la tipificaba como delito.

El Proyecto de Ley reguladora de la objeción de conciencia y de la prestación social substitutoria (hoy Ley en vigor) «puede considerarse positivo en la medida en que es la primera vez que en España se regula este derecho. Sin embargo, ello no obsta para que critiquemos el carácter restrictivo con que se ha hecho y que lo configura como una concesión que tiẹne que ser reconocida por el Consejo Nacional de Objeción de Conciencia» (los motivos por los cuales-un ciudadano español sujeto a obligaciones militares puede ser reconocido como objetor de conciencia son: los de conciencia en razón de una convicción de orden religioso, ético, moral, humanitario, filosófico u otros de la misma naturaleza) «en perjuicio de los ciudadanos que se declaran objetores, y limitando' de hecho su ejercicio» (frente a la prestación del servicio militar), «cosa que no ocurre con los demás derechos fundamentales recogidos en la Constitución».

(A. D. P.)

a la realidad social, ¿es posible ofrecer una «teoría» del derecho a través de la cual se pueda aprobar, por los órganos y las personas que lo «crean», un derecho positivo «accesible» a la mayor parte de los ciudadanos? Para responder a tales problemas se ofrece una panorámica («aproximativa») de las características más generales de los hábitos actuales de conocer el derecho («aproximaciones»). Tras lo cual, por tanto, se produce un acercamiento efectivo al estudio de las posibilidades existentes para dar satisfacción a los mandatos constitucionales y a la vinculación «democracia-razón-derecho».

En concreto se pone de manifiesto, primeramente, cuál es el modo «normal» de «aproximarse» al derecho por aquéllos de los que depende en la práctica la «confección» del derecho positivo: los juristas. En segundo lugar, se estudia el modo de acercarse al mismo por quienes están considerados desde hace varios años «autoridades» a la hora de proponer «teorías del derecho». En tercer lugar, es objeto de consideración la «aproximación» efectuada por las denominadas «teorías de la justificación del derecho», concluyendose con la reseña «alternativa» de las líneas generales de un acercamiento que tenga en cuenta la conexiôn de los términos que titulan al estudio. 
GALINDO AYUDA, Fernando.

La informática y sus consecuencias.

I Jornadas nacionales sobre informática en la enseñanza, Barbastro, 1985, págs. 25-31.

La escasa difusión social de las características y consecuencias de las tecnologías de la información y la comunicación hace preciso proponer, a todos aquellos que se ocupan en estos momentos de enseñar informática o sus aplicaciones, una expansión que manifieste la conciencia de todas estas consecuencias, en lugar de efectuar, como habitualmente se hace, una propagación meramente tecnocrática de las mismas.

En virtud de todo ello se expone en el artículo, en primer lugar, cuales son algunas de las características de los ordenadores en la actualidad, mostrando cómo estas máquinas substituyen el trabajo intelectual, mientras la industrialización primera sustituyó, a través de las máquinas, el trabajo manual. Lo que es mucho más importante en la actualidad si pensamos en que la denominada «inteligencia artificial» y los «sistemas expertos» comienzan a sustituir, en algunos aspectos, la dirección del trabajo intelectual y el manual, lo que anuncia para el futuro delicadas consecuencias.

Estas consecuencias se concretan, por ejemplo, en el hecho de que estas tecnologías elevan ingentemente la productividad. Por lo mismo en que crean paro, aunque éste sea coyuntural. También en que hacen precisa una reorganización de los hábitos humanos de trabajo al exigir que el trabajo del hombre y la máquina se complementen, lo que apenas ha sucedido de hecho en los países industrializados. Ahora bien, muy en especial, estas tecnologías tienen consecuencias políticas: es cierto que información es poder, y estas tecnologías han concentrado profusamente el poder en quienes lo tienen económica y políticamente a nivel «transnacional».

En virtud de todo ello, en el artículo se hace una propuesta de actuación para con estas tecnologías con respecto a los temas siguientes: protección de la intimidad personal, en el sentido de exigir del Estado y del derecho que

\section{GALINDO AYUDA, Fernando.}

\section{¿Qué enseñanza del derecho?}

\section{La enseñanza del Derecho, Zaragoza, 1985, págs. 43-64.}

En un momento como el presente, en el que, por mandato legal, pronto ha de producirse un cambio en la enseñanza del derecho, se hace necesario construir opiniones en torno al plan de estudios a implantar, o a qué tipo de enseñanza requieren las circunstancias sociales y políticas por las que pasa nuestro país. Derecho a opinar sobre este tema, como sobre todos los temas, lo tienen todos los ciudadanos, superada ya la vieja idea de que la enseñanza universitaria es una parcela de exclusiva competencia de la comunidad de profesores y estudiantes, una vez está aceptado que la Universidad es parte integrante del sistema social en su conjunto. Pese a todo, han de tener gran peso en la discusión al respecto, las opiniones de quienes participan, o han participado, directamente en la enseñanza del derecho: profesionales, estudiantes y profesores. Esto es así porque, al menos, estas opiniones sirven para introducir el tema: cuál es la «realidad» de la enseñanza del derecho. Lo que no es poco, una vez que éste es, inevitablemente, uno de los puntos de referencia de la discusión sobre la reforma necesaria en la enseñanza del derecho. Y lo es porque, a través de esta opinión, se pone de manifiesto tanto la situación de la «docencia» del derecho como el lugar que les corresponde a los técnicos en la discusión, lo que también es importante.

En este artículo se da cuenta, ejemplarmente, de las opiniones de los profesionales del derecho, de los estudiantes de las Facultades y de los profesores, sobre la enseñanza del derecho. En base a unas encuestas, que se mueven siempre en el entorno de la Facultad de Derecho de Zaragoza, se explica la posición de algunos integrantes de los grupos sociales citados sobre dos cuestiones fundamentales: la enseñanza del derecho que actualmente

\section{GALINDO AYUDA, Fernando.}

Un modelo de enseñanza de la informática jurídica para profesionales del derecho.

Actas. I Congreso Iberoamericano de informática jurídica, Madrid, 1985, págs. 99-111.

Los profesionales del derecho en general no tienen por qué conocer informática. Su obligación de aprendizaje, resumidamente, termina con el conocimiento de las leyes y de los diversos métodos existentes para producir una aplicación justa de las mismas. Esto es de consideración aun en el caso de que los juristas o los profesionales del derecho estén dispuestos a utilizar los ordenadores en su trabajo diario. Lo cierto es que cada día en mayor medida los ordenadores, y las restantes tecnologías de la comunicación y la información, están más próximos a sus hábitos de trabajo por varias razones, pudiendo utilizarse sin requerir conocimientos especiales. De otra forma hay que considerar al grupo de juristas que, junto con informaticos, lógicos, documentalistas y linguiistas, ha de preparar soluciones informáticas adecuadas a las necesidades profesionales de los juristas. También a aquéllos que tengan por obligación proponer leyes o normas que regulen las consecuencias sociales, económicas y políticas de la introducción de los ordenadores en la vida social diaria. A estos juristas es preciso enseñar informática, pero ¿hasta que punto?

Una primera respuesta ha de ser negativa: de ninguna manera hasta el punto en el que se llega, por lo general, en los manuales de informática juridica que se han publicado en los paises occidentales desde finales de los años sesenta hasta la actualidad. Estos manuales quedan afectados por el «espíritu» 0 «ideario» docente en el que se ha enseñado en las Facultades de Derecho españolas hasta hoy prácticamente. Como se sabe ésta es una enseñanza erudita, liberal, que pretende mostrar todos los conocimientos existentes en una determinada materia. Segundo, además de que esta enseñanza no es acorde con el tipo de sociedad en que nos encontramos, 
garanticen el ámbito de comportamientos políticos, sociales e individuales que son necesarios para la vida dẹl ciudadano en una democracia que funcione; compensación de la falta de satisfacción o realización en el trabajo que tiene lugar junto a los ordenadores; está en poder del Estado y la economía. Todo lo cual se resume en la propuesta de una política, para quienes se encargan de divulgar estas tecnologías, centrada en propugnar el protagonismo participativo de todos los interesados, individuos, sindicatos, grupos sociales, organizaciones de todo tipo, ciudadanos, partidos políticos, etc.

se imparte en las Facultades españolas (en su mayoría), y la enseñanza del derecho deseable. Con ello queda de relieve la respuesta de los «peritos» o «expertos» en derecho a la pregunta que encabeza al artículo y, por lo mismo, el papel que les corresponde interpretar en la futura reforma.

Aquí se refleja, en concreto, las opiniones de varios integrantes de los grupos sociales citados, justamente aquéllos que tienen en común el hecho de vivir y trabajar, estudiar, ensenar o investigar sobre derecho en Zaragoza entre los años 1979 y 1983, período en el que fueron realizadas las encuestas que reclamaron esas opiniones. La conclusión fundamental a deducir de estas respuestas depende del hecho de que unos y otros no ofrecen proposiciones con las que satisfacer la pregunta que titula a este trabajo. Los «peritos» manifiestan, eso sí, la necesidad de cambio de la enseñanza del derecho vigente en nuestra Universidad, pero en ningún caso formulan alternativas precisas. De ahí puede concluirse que la enseñanza del derecho precisa para nuestra sociedad es, predominantemente, aquella que se funda en la «imagen» del jurista que nuestra sociedad actual y la del próximo futuro reclaman. Es precisa a tales efectos la opinión que los diversos grupos sociales, así como los estudios técnicos (hechos por técnicos que no sean tan sólo juristas) realizados al efecto, sostengan, una vez no es suficiente la opinión de los juristas.

es, a todas luces, inapropiada para un área de conocimiento como la que aquí consideramos por razones centradas en el mismo curriculum del jurista: éste no está preparado para adquirir conocimientos informáticos suficientes como para conocer a fondo las aplicaciones habidas en el terreno del derecho. Por ello, resumidamente, cabe decir que hay que enseñar informática a los profesionales del derecho que estén interesados en construir aplicaciones o proponer leyes o normas que regulen las tecnologías de la información y la comunicación, hasta el punto de que los juristas estén capacitados para saber exponer ante informaticos lógicos documentalistas y lingüistas las necesidades sociales en el terreno del derecho a las que en mayor medida, aplicando los principios en los que se inspira el Estado de Derecho, puede atender la informática en el terreno del conocimiento y la aplicación del derecho.

En este sentido es preciso enseñar cuáles son las principales características de los ordenadores en el momento actual así como los rasgos principales de algunas de las aplicaciones más conocidas habidas hasta el momento en este campo o el derecho vigente sobre la materia. A estos efectos se propone en el artículo un modelo de enseñanza de la informática para los juristas que arranca de las consideraciones sobre cual ha de ser la formación y práctica profesional de los juristas en un Estado democrático, las características de los ordenadores actuales y las que se prevén de los ordenadores en el inmediato futuro y los problemas que encuentran las actuales aplicaciones de la informática al derecho. 
garanticen el ámbito de comportamientos políticos, sociales e individuales que son necesarios para la vida dẹl ciudadano en una democracia que funcione; compensación de la falta de satisfacción o realización en el trabajo que tiene lugar junto a los ordenadores; está en poder del Estado y la economía. Todo lo cual se resume en la propuesta de una política, para quienes se encargan de divulgar estas tecnologías, centrada en propugnar el protagonismo participativo de todos los interesados, individuos, sindicatos, grupos sociales, organizaciones de todo tipo, ciudadanos, partidos políticos, etc.

se imparte en las Facultades españolas (en su mayoría), y la enseñanza del derecho deseable. Con ello queda de relieve la respuesta de los «peritos» o «expertos» en derecho a la pregunta que encabeza al artículo y, por lo mismo, el papel que les corresponde interpretar en la futura reforma.

Aquí se refleja, en concreto, las opiniones de varios integrantes de los grupos sociales citados, justamente aquéllos que tienen en común el hecho de vivir y trabajar, estudiar, enseñar o investigar sobre derecho en Zaragoza entre los años 1979 y 1983, período en el que fueron realizadas las encuestas que reclamaron esas opiniones. La conclusión fundamental a deducir de estas respuestas depende del hecho de que unos y otros no ofrecen proposiciones con las que satisfacer la pregunta que titula a este trabajo. Los «peritos» manifiestan, eso sí, la necesidad de cambio de la enseñanza del derecho vigente en nuestra Universidad, pero en ningún caso formulan alternativas precisas. De ahí puede concluirse que la enseñanza del derecho precisa para nuestra sociedad es, predominantemente, aquélla que se funda en la «imagen» del jurista que nuestra sociedad actual y la del próximo futuro reclaman. Es precisa a tales efectos la opinión que los diversos grupos sociales, así como los estudios técnicos (hechos por técnicos que no sean tan sólo juristas) realizados al efecto, sostengan, una vez no es suficiente la opinión de los juristas.

es, a todas luces, inapropiada para un área de conocimiento como la que aquí consideramos por razones centradas en el mismo curriculum del jurista: éste no está preparado para adquirir conocimientos informáticos suficientes como para conocer a fondo las aplicaciones habidas en el terreno del derecho. Por ello, resumidamente, cabe decir que hay que ensenar informática a los profesionales del derecho que estén interesados en construir aplicaciones o proponer leyes o normas que regulen las tecnologías de la información y la comunicación, hasta el punto de que los juristas estén capacitados para saber exponer ante informaticos lógicos documentalistas y lingüistas las necesidades sociales en el terreno del derecho a las que en mayor medida, aplicando los principios en los que se inspira el Estado de Derecho, puede atender la informática en el terreno del conocimiento y la aplicación del derecho.

En este sentido es preciso enseñar cuáles son las principales características de los ordenadores en el momento actual así como los rasgos principales de algunas de las aplicaciones más conocidas habidas hasta el momento en este campo o el derecho vigente sobre la materia. A estos efectos se propone en el artículo un modelo de enseñanza de la informática para los juristas que arranca de las consideraciones sobre cual ha de ser la formación y práctica profesional de los juristas en un Estado democrático, las características de los ordenadores actuales y las que se prevén de los ordenadores en el inmediato futuro y los problemas que encuentran las actuales aplicaciones de la informática al derecho. 
tuar comunicativo), plural (el Derecho, concebido discursivamente, estaría constituido como pluralidad de discursos diversos: del legislador, de los jueces, de los teóricos...) y pragmático (recibe el Derecho de su razón de ser de la praxis y en la praxis). Esta visión del Derecho nos lleva a insertarlo en el ámbito de la razón práctica y a la consiguiente necesidad de delimitar las condiciones practicas de posibilidad del discurso jurídico racional.

El artículo termina con unas conclusiones finales en las que emite una valoración de conjunto del «Defensor Pacis» y de sus repercusiones.

(F. L. R.)

El capítulo cuarto trata el tema de la Ontología como descripción de los distintos espacios ontológicos que se dan en la realidad, poniendo de relieve las diferencias entre el enfoque ontológico y el científico. Esto supuesto, la Ontología jurídica tratará fundamentalmente de «situar al Derecho en la correspondiente región de la realidad» (p. 126), mediante la atribución al Derecho de una serie de propiedades esenciales que constituirán su connotación. La distinción entre Derecho, Moral y usos sociales es una de las tareas que ocupa al autor en este capítulo. Tal distinción supone una reflexión sobre la libertad humana y sus sentidos.

Finalmente, el capítulo quinto, bajo el rótulo Concepto y método del conocimiento del Derecho natural, estudia las distintas versiones del positivismo jurídico (filosófico, historicista, sociológico, legalista y metodológico) y las principales tendencias del pensamiento iusnaturalista (teoría universalista del Derecho natural, concepcion histórico relativista, iusnaturalismo universalista relativista). Sigue un análisis de las éticas contemporáneas y sus influencias en el Derecho natural. Por último, se ofrecen al lector, una serie de consideraciones críticas sobre el Derecho natural. Al final de la obra, aparece un gran apartado bibliográfico que importa destacar. 
GARZÓN VALDÉS, Ernesto (Compilador).

Derecho y filosófico.

Ed. Alfa, Barcelona, 1985, 218 págs.

El presente volumen recoge trabajos de siete filósofos del Derecho de Alemania Federal (Robert Alexy, La idea de una teoría procesal de la argumentación jurídica; Werner Becker, Los significados opuestos del concepto de consenso; Ralf Dreier, Derecho y Moral; Norbert Hoerster, Etica jurídica sin metafísica; Hartmut Kliemt, Acerca de la coherencia de un liberalismo individualista estricto; Werner Krawietz, Derecho y racionalidad en la moderna teoría del derecho; y Lothar Kuhlen, Violaciones de normas en el derecho y la moral) y ofrece una panorámica de lo que ha supuesto la renovación de la filosofía y la teoría del Derecho a partir de los años setenta en ese país.

Es de destacar el trabajo introductorio de Ernesto Garzón Valdés, que permite al lector de habla castellana contextualizar los ensayos incluidos en el libro y aprehender lo que han sido las líneas generales por las que ha discurrido la literatura iusfilosófica de Alemania occidental después de 1945. Su análisis parte de la constatación de la esterilidad de la polémica en torno a la responsabilidad del positivismo jurídico durante el período de dominación del nacional-socialismo. Esterilidad derivada de un diagnóstico equivocado: «La explicación de la arbitrariedad legal durante la época nacional-socialista a través de la actitud juspositivista de los juristas es histórica y conceptualmente falsa. Por el contrario, la vigencia de un jusnaturalismo cargado de una buena dosis de irracionalismo en conjunción con un decisioninno, que veía en el Fhürer al 'único legislador' de quien dependía en última instancia la validez de las normas, se presenta cada vez más claramente como el candidato adecuado para explicar lo sucedido en el campo del derecho entre 1933 y 1945 en Alemania» (pág. 7). Junto a ello hay que destacar las consecuencias negativas que para la filosofía de Derecho de las décadas siguientes

\section{GIL CREMADES, Juan José.}

Filosofía del Derecho en España (1960-1985).

Anales de la Cátedra Francisco Suárez, Granada, n. ${ }^{\circ}$ 25, 1985, págs. 225-245.

El autor intenta trazar una panorámica de los últimos veinticinco años de Filosofía del Derecho en España. Para ello, tras fracasar «en la busca de referencias aprovechables en esta engorrosa crónica» y «con las manos vacías, después de haber llamado a una y otra puerta», se detiene fundamentalmente en los dos siguientes puntos: a) «la variación de elementos estructurales, de parámetros que hoy sirvan para entender un poco nuestra situación comentando los cambios institucionales y las repercusiones que ellos han conllevado; y b) «la variación de temas y objetos de investigación» «procurando atisbar las razones de tales preferencias y de tales olvidos».

En relación con el primero de estos puntos, el autor principalmente comenta los influjos que sobre la asignatura han tenido en este período las distintas situaciones de poder político (con sus correlativas consecuencias institucionales) y de poder académico (con sus correlativas consecuencias de otro tipo), así como la transformación social vivida en España que, entre otros efectos, supuso para la Universidad masificación estudiantil y reclutamiento de un profesorado emergente, lo que transformó radicalmente las reglas del juego del poder académico. En relación con el segundo de los puntos, los temas tratados en los últimos veinticinco años de Filosofía del Derecho en España, el autor lejos de esquematizar o sistematizar la obra publicada «por unos y otros colegas» se limita a señalar algunos rasgos. Así, alude a «los manuales», «las traducciones», «los derechos humanos» $\mathrm{y}$ «las ausencias».

\section{GONZÁLEZ VICÉN, Felipe.}

\section{De Kant a Marx (Estudios de historia de las Ideas).}

Fernando Torres Editor, Valencia, 1984, 238 págs.

El autor reúne en este libro una serie de trabajos aparecidos -con una sola excepción- con posterioridad a 1979, fecha en que la Universidad de La Laguna editó, bajo el título de Estudiar de filosofía del Derecho, la mayor parte de los trabajos publicados hasta entonces por González Vicén. Los que integran esta nueva recopilación son los siguientes: La filosofía del Estado en Kant (Lección inaugural del curso académico de la Universidad de La Laguna, 1947-48); La escuela histórica del Derecho («Anales de la Cátedra F. Suárez» n. ${ }^{\circ} 18-19$, 1978-79); Filosofía y revolución en los primeros escritos de Marx («Sistema», n. ${ }^{\circ} 40$, enero de 1981); La crítica de Marx o la escuela histórica ("Sistema», n. ${ }^{\circ}$ 43-44, septiembre de 1981); Del Derecho natural al positivismo jurídico («Anales de la Universidad de La Laguna», Facultad de Derecho, t.IX, 1981-82).

Como se ve, se trata de trabajos centrados en problemas muy diversos, pero todos ellos tienen como tema general el estudio de la época que va desde finales del siglo XVIII a mediados del siglo XIX, es decir, «de Kant a Marx», una época decisiva para la constitución de las ideas y de las realidades sociales que forman la esencia de nuestro mundo contemporáneo. Para decirlo con las propias palabras del autor, estos trabajos «tratan de poner en claro un punto concreto en la historia de las ideas» y su «único denominador común es de naturaleza metódica, a saber, aquella premisa de todo el historicismo europeo que ya formulaba Savigny en sus lecciones universitarias de juventud: entender el objeto desde sí mismo, no desde puntos de vista abstractos, sino desde el horizonte en el que el objeto se hace real y cobra sentido». 
tuvo la interrupción, que supuso el nacional-socialismo, de la mejor tradición científica alemana, caracterizada fundamentalmente por el rigor metódico y la honestidad intelectual. Sin embargo, como explica Garzón Valdés la década de los cincuenta no se agota en la corriente de la «naturaleza de la cosa» ni en los intentos de ir «más allá del positivismo y del derecho natural», destacando tres excepciones: Ulrich Klug, Theodor Viehweg y Karl Engisch. Asimismo, la falsa superación del positivismo jurídico a la que antes he aludido tuvo como consecuencia un empobrecimiento de la filosofía del Derecho alemana en la década de los sesenta al generar un injustificado desinterés por las corrientes de la filosofía analítica y del realismo escandinavo. Son notorias ausencias tales como las de Hart, Ross o Bobbio.

Es en este contexto en el que debe situarse la renovación de la filosofía del Derecho alemana iniciada en los años sesenta, pudiéndose probablemente situar el punto de inflexión en 1970 con la aparición de la revista Rechtstheorie, donde «no deja de ser significativo el hecho de que entre sus editores figuraran, junto con Engisch y Klug, Hart, Kelsen y Popper». A partir de aquí cabe destacar dos procesos intelectuales que tendrán gran relevancia: por una parte, el esfuerzo por distanciar la «teoría del Derecho» de las versiones clásicas de la «filosofía jurídica entendida como doctrina del Derecho natural», y por otra parte, la llamada «rehabilitación racional de la filosofía práctica». Así, pues, los autores incluidos en este volumen ilustran los nuevos desarrollos de la teoría y la filosofía del Derecho alemanas.

Por último, tal vez merezca la pena llamar la atención sobre el hecho de que puede resultar útil para la lectura de este volumen tener en cuenta las respuestas de los autores del mismo a la encuesta sobre «problemas abiertos en la filosofía del Derecho» publicada en el n. ${ }^{\circ} 1$ de DOXA. 


\section{GONZÁLEZ VICÉN, Felipe.}

\section{La obediencia al Derecho. Una anticrítica.}

Sistema, Madrid, n. ${ }^{\circ}$ 65, marzo 1985, págs. 101-105.

El artículo constituye una respuesta a la polémica planteada por Elías Díaz en el libro De la maldad estatal y la soberanía popular a propósito del trabajo de González Vicen La obediencia al Derecho. El autor parte de la idea de que en gran medida «la polémica descansa en una interpretación equivocada y en un malentendido» de las tesis que ê sostiene. La conclusión a que llegaba González Vicén en ese trabajo era doble: a) mientras que no hay un fundamento ético para la obediencia al Derecho, b) si hay un fundamento ético absoluto para su desobediencia. En este sentido, según el autor, Elías Díaz combate denodadamente la primera conclusión y, aunque con muchas limitaciones, hace suya la segunda.

En relación con la primera, para el autor, la cuestión radica en que Elías Díaz tiene una concepción idealista del Derecho (Derecho es «una opción entre diversas perspectivas éticas.... expresión auténtica de diferentes conciencias individuales», un intento de aunar criterios éticos individuales expresados socialmente como soberanía popular y regla de las mayoría») que para aquél es «pura especulación a la que no corresponde realidad alguna» («Derecho es un orden coactivo de naturaleza histórica en el que se refleja el enfrentamiento de intereses muy concretos y el predominio de unos sobre otros... Un instrumento, empero, y aquí radica su contradicción de principio, que pretende revestir validez y obligatoriedad, no sólo para la clase cuyos intereses representa, sino para toda la sociedad»): Así, González Vicén argumenta que «si gozamos de las ventajas de una sociedad organizada, debemos cumplir sus exigencias, si el cumplimiento de las normas jurídicas por parte de los demás me hace posible el disfrute de ciertos derechos, es un imperativo del fair play que yo también cumpla las normas que hace posible el disfrute de sus derechos a los demás. AlDerecho hay que obedecerlo por éstas y otras

\section{GONZÁLEZ VICÉN, Felipe.}

Sobre el neokantismo lógico-jurídico.

Doxa, Alicante, n. ${ }^{\circ} 2,1985$, págs. 27-54.

En este artículo González Vicén trata de «comprender» el neokantismo (corriente filosófica de nuestro inmediato pasado) con el fin de desentrañar su significado para nuestro presente histórico. Para ello, parte de la negacion del tópico de que el neokantismo significa algo así como una restauración filosófica en una época que había perdido el hábito de filosofar, pues este discurre en gran medida paralelamente a otra tradición filosófica, la del positivismo, que ve en las sensaciones el dato primario de nuestra conciencia y en su asociación bajo la forma de conceptos el objeto último de la ciencia. El neokantismo, nos dirá el autor, «no trata de refutar esta dirección, de mostrar la falsedad de sus resultados, sino que pretende poner de manifiesto que el método por el que llega a tales resultados no puede nunca fundamentar de modo absoluto su verdad. Lo que se propone es reflexionar sobre aquello que el positivismo tiene como algo dado sin más, es decir, el proceso mismo del conocimiento». En esto radica la profunda analogía entre Kant y el neokantismo. Por tanto, lo que se halla en el fondo de éste no es simplemente «una masa de opinión centrada en el retorno a Kant», esto es, al Kant histórico, sino la construcción de una nueva filosofía partiendo de una parte muy determinada de la teoría kantiana, la teoría del conocimiento.

A continuación González Vicén se detiene en el estudio de los amores neokantianos más importantes en relación con la ciencia jurídica. Así, se refiere a H. Cohen y su intento de salvar la contradicción kantiana consistente en abandonar en la parte práctica de su filosofía la idea, que había seguido en su parte teórica, de que «toda filosofía está referida al factum de una ciencia». Este intento se concreta en la busca de una «matemática» para

\section{GIJISÁN, Esperanza.}

Justicia como felicidad.

Sistema, Madrid, n. ${ }^{\circ}$ 64, enero 1985, págs. 63-82.

La autora, en este artículo, se propone defender una tesis -«un tanto atrevida»- en torno a la justicia, que se concreta en los siguientes puntos:

1 - -«La justicia ha de entenderse no como fairness, únicamente, como ha sido sugerido por Rawls, sino, principalmente, como instrumento conducente a la happiness... Sería simplificar las cosas en exceso, sin embargo, proclamar ahora la vuelta a un utilitarismo naive, sin matizaciones. La tesis o propuesta que aquí se defiende tiene sus raíces tanto en Bentham como en Platón, en Mill como en Kant, en Hare como en Habermas». «Dicho sumariamente... La justicia no es sino el instrumento que potencia la felicidad general, $o$ el diálogo entre seres racionales a fin de que los intereses generalizables sean atendidos».

2.- «Sin embargo, se mantiene al mismo tiempo, siguiendo igualmente a Platón y a Mill, que la 'felicidad' tiene como componente importante el sentido de justicia. $\mathrm{O}$, lo que es igual, no cualquier estado de "contento" 0 'conformidad' por parte de los seres humanos es lo que cuenta. Es decir, se mantiene, con cautela por supuesto, que la felicidad no es simplemente un estado subjetivo... En la concepción que propongo de Justice as Hapiness, 'Hapiness' hace referencia a aquélla conseguida por los individuos más desarrollados para quienes se hace preciso tanto la auto-estima generada en el mono-diálogo, como el compartir intereses generalizables con los demás, como producto del diálogo $»$.

3.- «La justicia, o es un término abstracto absolutamente carente de significado, o no es sino la constatación de un desideratum humano. En otras palabras, las distintas teorías de la Justicia no son sino distintos modelos 
razones, pero lo que ninguna de ellas nos dice es que haya un fundamento ético para la obediencia... La obligación ética no puede nunca basarse en la heteronomía de razones o motivos de índole práctica, sino sólo en los imperativos de la conciencia individual».

En relación con la segunda conclusión, la discrepancia radica en que Elías Díaz parece encontrar en la libertad «el único valor cuya vulneración justifica la decisión ética de la desobediencia», mientras que González Vicén afirma que los valores cuya vulneración justifica la desobediencia los determina la conciencia individual sin someterse a una pauta previa. Por otro lado, González Vicén sostiene que la desobediencia ética al Derecho es una actitud personal y no una posición política: «Aquí radica la diferencia entre la desobediencia ética al Derecho y otras formas de desobediencia... La desobediencia civil representa un intento individual o colectivo de forzar la derogación de unas leyes o un cambio en la política del gobierno por medio de presiones externas, como la interrupción del tráfico, la negativa al pago de los impuestos... Nada de eso se da en la desobediencia ética al Derecho, la cual no pretende nada en concreto, es un acto d'absolue gratuité... No hay lugar, por eso, para decir que 'en ciertos países y en ciertas historias' la desobediencia es siempre 'golpista-reaccionaria'; la desobediencia ética no es ni progresista ni reaccionaria, sino que por su propia naturaleza se encuentra más allá de esta disyuntiva».

(J. A. R.)

las ciencias del espíritu en la que se contengan los supuestos puros de éstas. Cohen la hallará en la ciencia del Derecho. En segundo lugar, el autor estudia a R. Stammler, que partirá de la idea de que la «aspiración fundamental del entendimiento humano es llegar a un conocimiento revestido de validez general; no a lo transitorio y particular» Y de que esta aspiración en el campo de la reflexión jurídica se halla reflejada en la «teoría pura del Derecho», cuyo cometido es «la formulación de lo que puede afirmarse con validez general en cuestiones Jurídicas». Por último, en tercer lugar, el autor estudia extensamente a Kelsen, deteniéndose en su concepción de la realidad y en los elementos fundamentales de su «Teoría pura del Derecho».

Finalmente, González Vicén realiza una valoración de esta corriente de pensamiento, y concluye que «la idea del Derecho que se halla en la base del neokantismo significa la acumulación del proceso de positivación y formalización jurídicas al que asistimos desde mediados del siglo último... Es decir, que al contrario de lo que viene repitiendose un poco a la ligera, el neokantismo no crea una noción del Derecho sino que la encuentra conclusa y trata de instrumentarla conceptualmente. Esta noción es la del positivismo jurídico... Una noción vinculada a la existencia histórica de una clase social muy determinada es convertida en paradigma y modelo de toda reflexión filosófica... Llegados a este punto, podemos ver con claridad «las razones de su fracaso: de un lado, el intento vano de reducir a puras formas conceptuales la esencia de un fenómeno de naturaleza histórica, como es el Derecho; y, de otro, «haber tratado de hacerlo sin acertar a salir de la accidentalidad de una concepción jurídica determinada por la constelación social de su tiempo y por la estructura de su clase dominante».

(J. A. R.)

de cómo conseguir sociedades con individuos felices. O, lo que es igual, las propuestas relativas a qué ha de constituir la justicia no son sino propuestas, a la postre, de lo que constituirá una sociedad 'bien ordenada',
armónica, ajustada, en suma 'feliz'». 
HABERMAS, Jürgen.

Derecho y violencia. (Trad. de Juan Jose Gil Cremades).

Anuario de Filosofía del Derecho, Madrid, n. ${ }^{o} 2,1985$, págs. 19-35.

A mediados, de octubre de 1983 el movimiento pacifista de la República Federal Alemana organiza la «Semana» con el objetivo de impedir la instalación de misiles en su país. Se trata de una protesta masiva que incluye violaciones de normas -«solamente con el propósito de apelar a la razón y sentido común de una mayoríasque trata de ser justificada como desobediencia civil, concepto definido por John Rawls como «una acción püblica, pacífica, consciente, pero ilegal, que normalmente debe conllevar una modificación de las leyes o de la política gubernamental».

La desobediencia civil supone una protesta por medio del quebrantamiento calculado de las normas, apelando directamente a los principios fundamentales que legitiman la Constitución, en el marco de un Estado de Derecho reconocido como legítimo. Pero en el caso de la R.F.A. tanto instancias de poder tales como el Presidente, el Gobierno o el Tribunal Constitucional como la mayoría de los juristas consideran estos actos como violencias o coacciones contrarias no sólo a la ley penal, sino también a la misma Constitución, además de moralmente reprobables. Martin Kriele es representante de estas ideas y, recogiendo opiniones de otros juristas, afirma que la oposición al rearme es la manifestación de la lucha por el poder de una «élite» (o «contra-élite») formada por intelectuales, periodistas de izquierda, estudiantes, artistas, profesores ... que intentan imponerse sobre los representantes, elegidos y nombrados, del Estado, a través de su influencia en la sociedad. Se habla, en este sentido, incluso de guerra civil.

Para Habermas esta «teoría de la conjura» es poco menos que absurda, pero reveladora de lo que puede llamarse el «trauma alemán» (sospechas, recelos, obsesiones... surgidas del efecto en la conciencia del país de «la tran-

\section{HASSEMER, Winfried.}

\section{Hermenéutica y Derecho.}

Anales de la Cátedra Francisco Suárez, Granada, n. ${ }^{\circ} 25,1985$, págs. 63-85.

Este trabajo se estructura en cinco partes diferenciadas. En la primera (La Universidad de la Hermenéutica), el autor se centra en la idea de que «la hermenéutica no es un campo de ocupación científica, ni un ámbito de objetivos, ni una disciplina; es más bien un método de acercamiento científico a objetos, de formación de teorías y sistemas científicos; es un fenómeno estructural, que exige atención para cualquier actividad científica, que precede y forma la base de las ciencias particulares». Esta universalidad teórico-científica de la hermenéutica es importante en relación con el Derecho no sólo porque es condición previa para que esta tenga respuestas a cuestiones científico-jurídicas, sino porque es capaz de mediar técnico-científicamente entre el ámbito jurídico, y otras materias, permitiendo «abrir de nuevo la discusión sobre el carácter científico de la ciencia jurídica y fundamentarla de forma exigente». En la segunda parte (Comienzos) el autor traza un breve esquema de cómo se produjo la aproximación entre hermenéutica y Derecho («la hermenéutica jurídica es un hijo tardío de la hermenéutica general»), al tiempo que afirma que sólo cabe plantearse «el problema de un tratamiento correcto de la ley, de su aplicación correcta al caso» en la medida en que se comprenda que la ley es una decisión no unívoca, incompleta y abierta con respecto al futuro: sólo en este caso hay motivo para reflexionar sobre el papel productivo de aquél que interpreta o aplica la ley y para investigar acerca de los criterios de una interpretación o aplicación correctas. En la tercera (Aspectos esenciales), el autor procede a diferenciar a la hermenéutica jurídica de otras teorías jurídicas, centrándose principalmente en la teoría jurídica analítica y en la teoría del Derecho teórico-sistémica. La cuarta parte (Fuentes) se divide a su vez en otras dos: Metodología, en la

\section{HERNÁNDEZ GIL, Antonio.}

\section{De nuevo sobre el Derecho natural.}

Persona y Derecho, Pamplona, n. ${ }^{\circ} 12,1985$, págs. 13-65.

Este artículo es el discurso leído en la sesión inaugural del curso 1983-1984 en la Real Academia de Jurisprudencia y legislación. En él, el autor trata de explicar el fenómeno del ocaso del iusnaturalismo en el siglo XIX y las causas de su posterior renacimiento en el siglo XX. Este acontecimiento ha tenido en nuestro pais unas características peculiares. El autor busca los vestigios de iusnaturalismo en juristas españoles del siglo XIX. Distingue entre ellos a los neoescolásticos como Ceferino González, Ortí y Lara, Mendizábal Martín, por una parte, y Sanza del Río y Giner de los Ríos, por otra; estos últimos partiendo de presupuestos filosóficos claramente distintos a los de los anteriores, como es el pensamiento de Krause, admitían la existencia de un Derecho natural con caracteres específicos que los separaban de otras concepciones iusnaturalistas.

A continuación, el autor define lo que en este caso entiende por renacimiento: «un restablecimiento de una línea de pensamiento después de haberse producido la ruptura», y expresa cuáles son aquellos teóricos que, a su juicio, han contribuido a tal renacimiento en el siglo XX: Geny, Radbruch, Verdross, Maritain, Renard, Mesner, Erik Wolf, etc. Por lo que se refiere a España, y teniendo como marco cronológico el período comprendido entre 1939 y 1975, distingue entre el «iusnaturalismo neoescolástico pleno» (Corts Grau, Elías de Tejada, Galán y Gutiérrez, Luño Pena, etc.) y un «iusnaturalismo menos pleno de varias procedencias»; los autores que se citan en este último apartado son entre otros, Recaséns Siches y Legas Lacambra, cuyas raíces son muy paralelas: Ortega y su raciovitalismo y la teoría pura del Derecho de H. Kelsen.

Por lo que a las «nuevas concepciones del Derecho natural» se refiere, el autor menciona entre otras: el iusnatu- 
sición en forma legal de un estado democrático a un caudillismo totalitario» desde un principio claramente injusto), una de las causas de la desconfianza hacia la desobediencia civil y, en concreto, al movimiento pacifista. La otra causa -ésta teórica- está en el hobbesianismo alemán. Para Hobbes, el Estado tiene como principal función -que lo legitima- asegurar la paz interior del ciudadano, objetivo imposible sin un monopolio estatal de la fuerza, imposible «si el ciudadano decidiera por sí mismo cuándo se produce una resistencia justificada». Frente a la obediencia incondicional al Derecho que supone esta actitud se propugna una obediencia cualificada al mismo: no basta con una legitimación formal, procedimental, del Derecho positivo; se requiere una adecuación material a los principios constitucionales. Desde este punto de vista la desobediencia civil es el único medio del ciudadano de retornar su soberanía y exigir tal adecuación, pero ha de cumplir, para ser respetada por el Estado, las siguientes condiciones: el orden jurídico ha de permanecer intacto, el transgresor debe asumir las consecuencias de su acción (y el Estado debe aplicar la ley penal, sin perjuicio de conceder una amnistía) y, por último, debe fundamentar su desobediencia «en principios reconocidos y legitimadores de la Constitución». Queda tras estas reflexiones responder a la cuestión de la justificación como desobediencia civil de las violaciones de normas como protesta por la instalación de misiles en la R.F.A. Para Habermas la contestación es afirmativa: porque era el único medio de actuación del ciudadano y porque legitima tales actos la urgencia por frenar la carrera de armamentos, aun con medidas unilaterales.

(D. G. L.)

que el autor expone que «norma y caso (que según la metodología tradicional sólo se unirán tras la subsunción deductiva de la norma en el caso) tienen que relacionarse paulatinamente en el acto de obtención del Derecho, deben desarrollarse y concretarse mutuamente y, por tanto, se presuponen... Norma y caso real se producen mutuamente en el proceso de aplicación de la norma o de decisión del caso»; y Filosofía del Derecho en la que el autor nos dirá que «el punto de partida de la hermenéutica jurídica orientada filosófico-jurídicamente... es la relación entre Derecho y ley, entre esencia y existencia, entre deber ser y ser». Y, por último, en Puntos principales, el autor se detiene en el argumento de que el «deber ser y el ser, la norma y el caso sólo pueden llegar a ser productivos mutuamente si se supera la separación metodológico-dualista, si se señala un puente entre ellos, que no sólo los vincule entre sí, sino que los una indisolublemente».

(J. A. R.)

ralismo historicista; el iusnaturalismo de base existencialista (Maihofer y Welzel); el iusnaturalismo axiológico (Reale y Cossio). En el seno de la corriente denominada «doctrina de la naturaleza de las cosas» destaca el autor cómo esta teoría ha sido interpretada de distintas formas; Maihofer y Welzel en Alemania la han interpretado de manera distinta a como lo ha hecho M. Villey en Francia; igualmente desde sectores alejados del iusnaturalismo ha recibido interpretaciones distintas, por parte de amores como Poulantzas o Bobbio. Posteriormente, el artículo hace referencia a la doctrina de M. Villey sobre las bases aristotélico-tomistas de la doctrina iusnaturalista desarrolladas por autores de diversa significación. Concluye el artículo con una valoración de conjunto del iusnaturalismo centrada en tres consecuencias que se derivan de una concepción iusnaturalista: «l) la posibilidad de desarrollar una posición crítica respecto a los Derechos positivos; 2) mantener la esperanza abierta hacia un Derecho justo: 3 ) erigir en centro de la protección jurídica a la persona». 
La contemporaneidad en la filosofía del Derecho.

Revista de la Facultad de Derecho de la Universidad Complutense, Madrid, n. ${ }^{\circ} 71,1984-85$, págs. 207-247.

El presente artículo reproduce el discurso leído en la sesión inaugural del curso 1985-86 de la Real Academia de Jurisprudencia y Legislación por Hernández Gil en calidad de presidente de la misma. El artículo arranca con una aproximación al significado de la contemporaneidad que -en palabras del autor- comprende «nuestro entorno histórico más próximo. Aunque su demarcación cronológica es diversa, en parte por la materia a que se aplique y en parte también por arbitraria. La última o mas reciente etapa de la contemporaneidad es la actualidad que, además de comprender el hoy estricto, apunta al devenir».

Así, a continuación, el autor se detiene en el desarrollo de los siguientes epígrafes: II) La contemporaneidad en la filosofía y las tendencias filosóficas contemporáneas; III)-Visión panorámica de la actualidad; IV) La contemporaneidad en la filosofía del Derecho y las tendencias contemporáneas: A) La peculiaridad del pensamientojurídico, B) El llamado concepto histórico de la filosofía del Derecho y su crítica, C) El despertar de la filosofía jurídica con el neokantismo; V) Las corrientes filosófico-jurídicas contemporáneas: A) Entrecruzamientos de cuestiones filosóficas, científicas y sociológicas, B) Delimitación de las principales corrientes contemporáneas; VI) Las corrientes filosóficas generales contemporáneas y su proyección en la filosofía jurídica: A) La fenomenología: B) La filosofía de la vida, C) El existencialismo, D) El positivismo lógico y la filosofía analítica, E) El estructuralismo, F) El marxismo, G) La filosofía en dispersión; VII) Corrientes filosóficas intrajurídicas; VIII) Las corrientes metodologicas.

(J. A. R.)

\section{HERRERA FLORES, Joaquín.}

Presupuestos para la consideración de la paz como valor jurídico.

Anuario de Filosofía del Derecho, Madrid, n. ${ }^{\circ}$ 2, 1985, págs. 107-123.

Partiendo de la urgencia de la búsqueda de la paz fuera de la lógica militar e imperialista, plantea este artículo el estudio de la misma como valor jurídico desde dos perspectivas: a) inmersa en el conjunto de valora jurídicos fundamentales y b) como principio recogido en textos constitucionales.

a) La paz puede considerarse como fin último y absoluto por encima del resto de valores (pacifismo ético o puro) o como medio en el que éstos se desarrollan y referida a condiciones sociales e históricas concretas que condicionan la toma de postura acerca de ella (pacifismo político o cuasi-pacifismo). Siguiendo la línea marcada por esta segunda visión y si se estima que no sólo la paz, sino todos los valores fundamentales del ordenamiento jurídico responden a una realidad social y son, por tanto, relativos (lo demuestra la historia), no podemos aspirar a establecer una jerarquía de los mismos ni desde un plano ideológico ni desde un plano práctico. Por ello, el autor opina que «entre libertad, igualdad, justicia, desarrollo social y cultural y paz no hay jerarquías absolutas, sino un continuo movimiento de prioridades que se concreta según los díferentes momentos históricos». Si, además, la par es el marco que posibilita los demás principios, podemos deducir de ahí, dos consecuencias: su urgencia y prioridad hoy; y su carácter conservador, no en el sentido tradicional y político del término (frente a Bobbio, que lo deducía del hecho de que la propaganda pacifista se asimila más por la sociedad cuando ésta más tiene que perder y, por tanto, que proteger), sino en cuanto que la paz tiende a mantener las condiciones indispensables para la existencia del resto de los valores.

b) Desde un análisis de Derecho comparado se observa que las referencias en las constituciones a la paz como bien jurídico protegido son más escasas que las correspondientes a la libertad, igualdad, justicia. Tales referen-

- . . . . .

\section{HERRERA FLORES, Joaquín.}

A propósito de la fundamentación de los derechos humanos y de la interpretación de los derechas fundamentales.

Revista de Estudios Políticos, Madrid, n. ${ }^{\circ}$ 45, 1985.

Las transformaciones que está sufriendo la categoría de Estado Social de Derecho y la propia dinámica de los sistemas de legitimidad imperantes en el mundo contemporáneo, han abierto de nuevo las puertas a temas tales como la fundamentación de los valores jurídicos, después de bastantes décadas de abandono y relativo desprecio. Este artículo quiere dar cuenta de esta dinámica centrando el análisis en el comentario a la obra del Prof. Perea Luño Derechos Humanos, Estado de Derecho y Constitución (Madrid, 1984).

La monografía consta de dos partes: en primer lugar, se repasa la exigencia de fundamentos nuevos que posibiliten un entendimiento actual de los valores jurídicos y/o sociales; y, en un segundo momento, se pretende mostrar la virtualidad de las nuevas teorías interpretativas que posibilitan un acercamiento evolutivo e institucional a la constitución como norma básica.

El punto nodal de la argumentación gira sobre la convicción de que una teoría general de los derechos humanos y de los derechos fundamentales sólo puede desarrollarse cuando previamente la comunidad de investigadores haya alcanzado un acuerdo «mínimo» acerca del posible fundamento de los mismos. Temas tales como el del «contenido esencial» de los derechos fundamentales, el de la «eficacia horizontal» de las partes dogmáticas, o el de la necesidad de adaptación de las tablas de valores juridificados a las condiciones sociales, políticas y culturales del presente, sólo encuentran vía de salida cuando el investigador y el aplicador jurídicos parten de ese acuerdo expresado a nivel puramente formal. Las teorías acerca de la «comunidad real e ideal de comunicación», analizadas paralelamente a los esfuerzos por concretar la misma en base al conjunto de «necesidades 
cias pueden encontrarse en los preámbulos de los textos constitucionales (en cuyo caso se plantea la cuestión de su fuerza normativa, que suele resolverse afirmativamente) y. junto a los principios fundamentales, ya en el articulado. Ejemplos de todo ello tenemos en constituciones que responden al modelo del Estado Social de Derecho y en otras del campo socialista. Así, en nuestra actual Constitución la paz se eleva en el Preámbulo a criterio ordenador del resto del Ordenamiento.

Respecto a las constituciones socialistas hay que señalar, por último, que responden a un pacifismo realista y de contenido concreto que va más allá de la mera declaración de principios utópicos.

(D. G. L.)

radicales» de la población, constituyen el marco preciso para que este acuerdo consiga el suficiente grado de aceptación y consenso. 
HERRERA FLORES, Joaquín.

La participación política en John Rawls y el concepto de participación democrática.

Revista de las Cortes Generales, Madrid, n. ${ }^{\circ}$ 5, 1985.

En nuestro ámbito jurídico-político es ya casi un lugar común oír hablar de la necesidad de profundizar en la idea de democracia. Sin embargo, con sólo prestar un mínimo de atención se observa que el uso que se le da al término es tan ambiguo como ideológico. Una de las corrientes filosóficas que se ha planteado este tema con mayor atención, ha sido la corriente neocontractualista, la cual intenta fundamentar una nueva concepción del tema estudiado reduciendo su complejidad al ámbito meramente político.

Este ensayo intenta dar cuenta de esos dos hechos, abogando por una concepción amplia de la idea de democracia, y discutiendo con el autor de Teoría de la Justicia sus argumentos restringidos acerca de la participación en el mundo contemporáneo. Concretamente, el artículo consta de tres partes diferenciadas pero estrechamente imbricadas. En primer lugar se repasa la respuesta neocontractualista a la tan traída y llevada «Crisis de la democracia» dando cuenta de la ambigüedad que subyace a toda posición que pretenda aislar el hecho democrático de sus condicionamientos sociales. En un segundo momento se aborda el mismo tema pero esta vez incidiendo en la diferente concepción que de la participación tienen Rawls y el amor del artículo. La diferencia entre ambas concepciones puede verse si nos acercamos al concepto de participación democrática ofrecido por el autor del artículo: «... conjunto de derechos e instituciones, que tanto a un nivel político como social vanpropiciando el acercamiento de las expectativas individuales y grupales a las exigencias de la sociedad como comunidad política y, paralelamente, el control de los resortes públicos y sociales por los detentadores de la soberanía...» (p. 154).

\section{JEAMMEAUD, Antoine.}

«Critique du droit» en Francia: de la búsqueda de una teoría materialista del Derecho al estudio crítico de la regulación jurídico. (Trad. de Mariano Maresca).

Anales de la Cátedra Francisco Suárez, Granada, n. 25, 1985, págs. 105-135.

Este trabajo constituye un balance de la corriente de pensamiento jurídico francés Critique du droit, corriente que se ha venido expresando desde la segunda mitad de los años setenta a través de la colección de libros que lleva ese mismo nombre y de la revista Procès. En este sentido, en primer lugar, el autor resalta la escasísima influencia que esta corriente ha tenido en Francia (no así en otros paises; incluidos los del llamado socialismo realmente existente) debido, en parte, a problemas de edición y distribución, y, en parte, a la escasa acogida por un público al que en principio se pretendía interesar. A continuación, bajo el epígrafe de Las vicisitudes de lo constitución de una teoría crítica del Derecho, el autor alude al «proyecto científico contra "ciencia del derecho' tradicional», que consistía en tratar de construir «un auténtico conocimiento científíco capaz de marcar de manera decisiva la formación de los futuros juristas». Se trataba de afirmar, frente al iusnaturalismo y al positivismo (ambos de inspiración idealista), que el objeto de las investigaciones que pretenden explicar la aparición, las funciones y las transformaciones de lo jurídico no puede ser otro que ese modo de representación, ordenación y reproducción de las relaciones sociales que se denomina «lo político-jurídico»; y si ello se conecta con «la fórmula marxiana de que las reglas jurídicas y las formas políticas no pueden ser comprendidas por sí mismas, sino atendiendo a sus raíces en las condiciones de la vida material», se verá que lo importante de este proyecto científico radicaba en el esclarecimiento de las modalidades de relaciones entre estas condiciones de vida material y las formas juridico-políticas. Así, el autor enumera algunas de las tesis sostenidas por Critique du droit y que pueden suponer avances reales en la línea expuesta.

\section{KAUFMANN, Arthur.}

\section{Teoría de la justicia. Un ensayo histórico-problemático.}

Anales de la Cátedra Francisco Suárez, Granada, n. ${ }^{\circ}$ 25, 1985, págs. 37-62.

Para el autor, las dos preguntas fundamentales de la filosofía del Derecho son: qué es el Derecho justo y cómo lo reconocemos, es decir, cómo realizamos el Derecho justo. Durante mucho tiempo -nos dice el amor- se ha creído que ambas preguntas podían plantearse y contestarse completamente separadas la una de la otra el Derecho justo se presentaba como un objeto sustancial «que se opone a nuestro pensamiento y ha de ser captado por el 'sujeto' en su pura calidad de ser-en-si, es decir, sin mezclarlo con ningún elemento subjetivo. Según este planteamiento, el problema del conocimiento se reduce a la simple reproducción del objeto en la conciencia. Tal fue el ideal de la ciencia en la época moderna, orientada por el modelo de las ciencias naturales». Sin embargo, lo cierto es que el mundo no puede ser considerado y juzgado exclusivamente según criterios y categorías científico-naturales. Ni siquiera en el ámbito de las ciencias naturales son siempre posibles los resultados objetivos. Esto vale todavía mas para las ciencias comprensivas, pues en ellas el esquema sujeto-objeto es erróneo. «En la ciencia del derecho -y más aún en la filosofía del Derecho- no existen conocimientos que no hayan sido acuñados por quienes se ocupan del Derecho, y también interviene siempre (aunque no sea el único) un aspecto creador: el 'conocimiento' del Derecho tiene siempre algo de 'conformación del Derecho. Más claro aún: el Derecho material-positivo sólo surge en el proceso de realización del Derecho... Tampoco la justicia existe más allá de los veredictos de justicia que siempre contienen un momento racional y otro emocional. Desde esta perspectiva, el cómo de nuestro proceso de conocimiento y de nuestros juicios debe tener una importancia incomparablemente mayor que en el modelo sustancial-ontológico». 
El artículo culmina con el análisis pormenorizado del modelo participativo que configura «formalmente» nuestra Constitución de 1978, las vías institucionales de desarrollo de la participación, y los principios constitucionales reconducibles a la misma.

Más adelante, el autor se detiene, por un lado, en el cambio de orientación operado en el interior de Critique du droit, fruto principalmente de la toma de conciencia de los límites de la teorización materialista de lo jurídi$c o, y$, por otro lado, en la fijación de nuevos objetivos orientados fundamentalmente hacia la tecnología y la práctica de la regulación jurídica.

(J. A. R.)

A partir de este planteamiento, el autor entabla una discusión histórico-problemática (la historia de la filosofía como historia de problemas filosóficos) que abarca desde los autores de la antigüedad hasta los autores contemporáneos. 
KRIELE, Martín.

Política de paz en la encrucijada. (Trad. de Juan José Gil Cremades)

Anuario de Filosofía del Derecho, Madrid, n. ${ }^{\circ} 2$, 1985, págs. 33-43.

La política de paz se encuentra en la confluencia de dos caminos: uno, el de los medios jurídicos proporcionados por el Derecho Internacional y, otro, el de la opción unilateral (tesis de Habermas que para el autor consiste en que, Occidenteproscriba unilateralmente sus armas nucleares); estas vías son entre sí, excluyentes, pero -en la realidad política- es preciso elegir una u otra.

En este trabajo se sostiene que la única posibilidad de desarme se encuentra en que la Unión Soviética acepte la disposición a negociar y se empeñe en acuerdos que garanticen la seguridad recíproca. Se advierte que la elección de la política de pasos unilaterales eliminaría las motivaciones para hacer concesiones o abriría a aquel Estado la esperanza de un poderío mundial basado en el armamento nuclear. Sin embargo, el movimiento pacifista alemán argumenta -confiando en un efecto transformador de la moral- «que el acto de una primera prestación pudiera crear un clima de confianza sin amenazas ni enemistades y mover también a la Unión Soviética a una reducción unilateral de su armamento atómico».

El profesor Kriele señala que las iniciativas llevadas a cabo en este sentido en la República Federal Alemana han resultado contraproducentes. Por un lado, las reivindicaciones del pacifismo pidiendo la interrupción de la carrera de armamentos y la desviación del rearme, en 1983, hicieron que la Unión Soviética advirtiera que su creciente amenaza nuclear a Europa occidental hacía más fuerte la presion de los pacifistas sobre los americanos para que éstos cedieran, por lo que se vio animada a una intransigencia absoluta en las concesiones y a seguir aumentando su potencial atómico para amenazar a Europa. Por otro lado, el gobierno de Brandt, unos años atrás, quiso crear un clima de confianza en la disposición pacifica de su país, persuadido de que con ello

\section{LAPORTA, Francisco.}

El principio de igualdad: Introducción a su análisis.

Sistema, Madrid, n. ${ }^{\circ}$ 67, julio de 1985, págs. 3-33.

Este artículo analiza el principio de igualdad tanto desde un punto de vista 16gico. para desvelar sus ambigüedades, sentido y límites, como desde una perspectiva normativa. La perspectiva normativa, como el autor manifiesta expresamente, incluye tres enfoques diferentes: a) la igualdad o desigualdad no están determinadas por hechos «sino que son simplemente un producto de la estructura normativa de la sociedad»; b) «la idea de igualdad es un principio y no una descripción genérica de la realidad»; c) el principio de igualdad es una metanorma respecto de las normas sociales. Es ésta última dimensión la que tiene más relevancia puesto que los principios pueden funcionar como «razones» justificadoras de normas particulares que sean concreciones suyas; hay, por tanto, una clara interdependencia entre el principio de igualdad y su concreción en normas generales. La conclusión a que llega el autor examinando esa interdependencia es que el principio de igualdad «se expresa a través de principios y normas de segundo orden, a los que explica y justifica».

A partir de la dicotomía que establece el autor «a diferencias irrelevantes, tratamiento igual» «a diferencias relevantes tratamiento diferencial» se examinan cuatro concreciones materiales del principio de igualdad: a) principio de satisfacción de necesidades: b) principio de retribución; c) principio de reconocimiento de aptitudes y d) principio de consideración de status.

Concluye el artículo con un epígrafe dedicado al análisis de la distinción entre igualdad formal e igualdad material. En él se destaca, entre otras cosas, que la igualdad económica se determina a través de juicios de valor y normas (no de manera descriptiva y objetiva). En conexión con esto se subraya que el hecho de que las normas jurídicas puedan realizar el principio de igualdad puede interpretarse de tres maneras: 1) las normas jurídicas

\section{LAPORTA, Francisco.}

\section{Una vindicación del utilitarismo: Acotaciones a un libro de Martin D. Farrell.}

Sistema, Madrid, n. ${ }^{\circ}$ 64, enero 1985, págs. 125-133.

El artículo constituye una nota al libro de Martín Diego Farrell Utilitarismo: Ética y Política y pretende «además de hacer un breve inventario de los temas que presenta el libro, mantener un pequeño diálogo inicial con Farrell sobre la propuesta de modificación del utilitarismo que se contiene en su última parte». En relación con esto último, Laporta, expone cómo Farrell presenta un esquema utilitarista que incorpora el postulado central de la teoría de Dworkin del derecho a igual consideración y respeto; y explica cómo éste aplica el nuevo modelo a tres ejemplos conocidos en los que la teoría utilitarista parece obtener resultados insatisfactorios, llegando, así, auna solución distinta a la que llegaría un utilitarista «irrestricto». Pues bien, lo que Laporta sostiene es que se puede estar de acuerdo con la solución que Farrell da a los tres casos y pensar, sin embargo, que no llega a ella realmente mediante una modificación del utilitarismo, sino aplicando con cierta fuerza una teoría de los derechos individuales a la que, eso sí, se complementa subsidiariamente en ciertos casos con una teoría utilitarista. «En la propuesta de Farrell -escribe Laporta- se conserva, aparentemente, el cuerpo básico de la teoría utilitarista y se añade a ella, con funciones precisas, la presencia de un 'derecho determinado'. Así, el modelo aparece como un utilitarismo limitado y enriquecido. Pero en mi opinión esto no es más que la apariencia. La realidad es que la modificación y el enriquecimiento son tan grandes que la han transformado plenamente en una teoría de los derechos individuales. ¿Cómo se ha llegado a ello? Pues, a mi juicio, a través del concepto de 'derecho a igual consideración y respeto'». 
se sentarían las bases para negociaciones con posibilidad de éxito. La reacción soviética consistió en aceptar las ventajas que política y económicamente pudieran derivarse de ello, pero la confianza en el efecto transformador del impulso moral dado se frustró: «se dirigieron hacia nosotros 350 cohetes de alcance medio provistos de múltiple cabera nuclear y se encargó un poderoso potencial atómico disuasorio».

Pero no sólo el intento de «eliminación de la efigie del enemigo» dio al traste con las expectativas de un acercamiento a la paz, sino que incluso el más absoluto servilismo a la U.R.S.S. (que situara a la R.F.A. bajo una verdadera Pax soviética) no haría más que aumentar el peligro atómico para Occidente: se malograría el interés por las negociaciones, la amenaza atómica a Europa occidental sería irreversible, y el riesgo de guerra como consecuencia de un error político de calculo crecería.

Para terminar, volviendo sobre los resultados negativos a que la experiencia pacifista condujo, el amor reflexiona acerca de las causas de que los movimientos de masas frecuentemente produzcan lo contrario de lo que persiguen. Después de aportar una serie de ejemplos históricos en los que fundamentar tal hipótesis, concluye que lọs criterios de actuación se encuentran condicionados no ya por juicios morales sobre lo justo y lo injusto, sino por «las supuestas tendencias de la historia»: el presunto vencedor tiene razón. Los miembros del actual movimiento pacifista se encuentran fascinados por la amenaza soviética sobre Europa occidental, la fuerza sugestiva de su eventual victoria y la idea de que «el socialismo vence» les cautiva. Se hallan a la espera de una paz soviética, expectativa a la que en opinión del amor se ha de poner fin mostrando la impotencia del pacifismo para conducir a la Unión Soviética a la negociación.

(A. D. P.)

suelen tener carácter general y abstracto; 2) las normas jurídicas utilizan otro criterio de igualdad distinto del mencionado; 3) las normas jurídicas pueden incorporar el principio de igualdad, pero hay un hiato entre la vigencia formal y la eficacia social de esas normas. Se suele presentar así el principio de igualdad como un criterio de distribución por razones relevantes, más un criterio de distribución de renta por razones operativas. En el fondo de este planteamiento, de las dos igualdades, lo que subyace es el problema de la convivencia del principio de igualdad con el sistemaeconómico de mercado. En este sentido, la producción de bienes y el principio de igualdad son altamente compatibles. Donde surgen los problemas es en el plano de la distribución de los bienes producidos en un sistema económico desigualitario. Aquí el conflicto entre operatividad ética y operatividad económica es inevitable; hay que establecer, pues, una jerarquía, en la que el criterio más aceptable parece ser el de proponer un sistema económico de mercado únicamente como sistema de producción, pero no de distribución, «y ello por razones morales».

(F. L. R.) 
LÓPEZ CALERA, Nicolás M. ${ }^{a}$

\section{Filosofía del Derecho.}

Ed. Comares, Granada, 1985, 234 págs.

Este libro tiene su origen en una serie de «unidades didácticas» publicadas por la U.N.E.D. en 1976. Su pretensión y forma no es la de ser un tratado sistemático sino, como manifiesta el autor, se trata más bien de una «introducción a algunos temas de teoría jurídica y un breve panorama de algunas ideologías jurídicas dominantes». El punto de partida es la consideración de la Filosofía del Derecho como una teoría critica del Derecho. Esto implica cuestionar el propio objeto de estudio de los científicos del Derecho (las normas y el fenómeno normativo) y las metodologías empleadas por éstos. Tal planteamiento supone que la realidad jurídica no queda agotada en el estudio científico del Derecho sino que, además, hay una serie de problemas y preguntas que desbordan el ámbito de las distintas ciencias jurídicas y que son el objeto de una filosofía crítica basada en una «razón trascendente». Tal razón no es intemporal y ahistórica sino que se reconoce a sí misma inserta en una sociedad y condicionada por estructuras económicas, de clase donde existen códigos morales heterogéneos y enfrentados. El presupuesto explícito de toda esta argumentación se encuentra basado en la idea de que la historia humana es intrínsecamente dialéctica. En el plano jurídico, esta dialéctica se manifiesta en tensiones irreconciliables entre razón/fuerza, objetividad/subjetividad,individualidad/sociabilidad,libertad/autoridad.

El segundo capítulo, bajo el título Marxismo y Derecho, hace explícitos los presupuestos del materialismo dialéctico e histórico que resultan imprescindibles para una comprensión del Derecho desde esa perspectiva. Esto nos conduce al clásico e ineludible tema de si existe o no una teoría marxista del Derecho. Aquí, contrapone el autor las tesis de Cerroni («falta por elaborarse una teoría marxista del Derecho») a las de I. Szabo, según el cual la teoría marxista del Derecho ha sido elaborada y sistematizada fundamentalmente por los teóricos mar|. - xistas del Derecho de la Unión Soviética. A continuación se expliçan y y comentan brevemente las tesis sobre

\section{LÓPEZ CALERA, Nicolás M. ${ }^{a}$}

La Cátedra «Francisco Suárez» de la Universidad de Granada (1939-1985).

Anales de la Cátedra Francisco Suárez, Granada, n. 25, 1985, págs. 1-11.

El artículo recoge la evolución histórica de la Cátedra Francisco Suárez desde sus orígenes hasta nuestros días. Así, el autor parte de los objetivos con que nació en 1939 la referida Cátedra que, fundamentalmente, pueden resumirse en un objetivo académico: cumplir funciones docentes e investigadoras con vocación interdisciplinar, llenando un vacío en los planes de estudio entonces vigentes; y un objetivo político: difundir y potenciar los principios y doctrinas ideológicas nacidos con la sublevación del 18 de julio. Para documentar estas afirmaciones, el autor se centra fundamentalmente en el preámbulo del Decreto (de 9 de noviembre de 1939) por el cual se creaba la Cátedra y en el discurso del profesor Corts Grau en el acto de inauguración de sus actividades. Ahora bien, en una primera época -que llega hasta 1948- la Cátedra «llevó una vida relativamente lánguida». Sus actividades más sobresalientes en este período, al margen de la constante propagación de la filosofía escolástica o perenne con especial referencia a la Escuela Española, estuvieron centradas en la conmemoración de dos centenarios: en 1945 el cuarto Centenario del Concilio de Trento con la participación entre otros de Alvaro D’Ors, Joaquín Pérez Villanueva, P. Beltrán de Heredia, P. José A. de Aldama y Enrique Gómez Arboleya; y en 1948 el IV Centenario del nacimiento de Francisco Suárez con la participación de Enrique Gómez Arboleya, Heinrich Rommen, Antonio Truyol y Serra y Camilo Barcia Trelles.

En una segunda etapa, entre 1948 y 1957, la Cátedra se limita a organizar pequeños ciclos de conferencias sin gran trascendencia ni relieve. Sin embargo, a partir de 1957, con la incorporación del profesor Agustín de Asís a la Cátedra de Derecho Natural y Filosofía del Derecho de la Universidad de Granada, se producirá una poten-

\section{LORCA NAVARRETE, José F.}

Filosofía del Derecho. Perfiles sistemático-metodológicos.

Ed. Alhambra (Col. Mezquita), Madrid, 1985, 147 págs.

La constante preocupación del autor por indagar los fundamentos últimos del Derecho queda plasmada en esta obra en la que, partiendo de su cosmovisión cristiana y de acuerdo con una metodología declaradamente escolástica, reivindica la consideración del Derecho natural como médula de la Filosofía jurídica, por entender que en el «se funden en armonía cabal los variables cambios que caben en la especulación sobre el Derecho». Así, el trabajo se inicia con una amplia introducción en la que el autor se plantea la necesidad propedéutica de abordar los aspectos pedagógicos que caracterizan la ensenanza de las disciplinas iusfilosóficas, subrayando que la primera y principal tarea de la Universidad es la de formar más que la de enseñar, y que, por lo que se refiere a los estudios jurídicos, el acoplamiento de las dos disciplinas, Derecho natural y Filosofía del Derecho, permite conseguir una formación universitaria y completa. A continuación, en los siete capítulos de que consta este libro, se replantea la noción del saber filosófico, estudiando su desenvolvimiento etimológico, sus notas características, su estructuración y su posibilidad, reiterando su conclusión -ya expuesta en anteriores trabajos- de que su sentido y carácter supone una «inexorable apetencia humana de saber total, como verdad sintetizadora ultima de las verdades parciales de los saberes especializados y como hitos sucesivos a donde llegó la razón humana arrastrada por la comezón de conseguir la verdad última»; para entrar, seguidamente, en el análisis de saber filosófico-jurídico cuya problemática fundamental continúa siendo el Derecho natural en cuanto permanente reflexión acerca de la justicia. Aquí estudia la trayectoria histórica del término «Filosofía del Derecho» y estructura su contenido sistemático -tras un análisis previo de la problemática metodológica que afecta a 
el Derecho sostenidas por Marx, Engels, Lenin, Stucka, Pasukanis y Vischinsky. El capítulo concluye con un breve análisis de las aportaciones del «neomarxismo occidental», cotejándolo con las teorías sobre el Derecho desarrolladas en los países de influencia soviética.

El capítulo tercero está dedicado al análisis de la teoría pura del Derecho de Kelsen. Aquí se tratan de desvelar ideas claves con las que opera Kelsen; el autor, hace hincapié, fundamentalmente, en los conceptos de ciencia y de ideología que usa Kelsen, ya que ambos sirven para demarcar los distintos tipos de ciencia (causalidad/imputación) de los saberes metafísicos y de las puras ideologías. Hay en este capítulo una breve referencia a la 1dea de justicia que sostiene Kelsen, explicitando su relativismo ético.

El cuarto capítulo está dedicado a la exposición del realismo escandinavo. Comienza con un breve análisis de las teorías de A. Hägerströn y V. Lundsted, para pasar luego al análisis de los clásicos del realismo escandinavo: Olivecrona y Ross. Por último, este capítulo incluye un epígrafe titulado «El realismo jurídico escandinavo como ideología burguesa».

El capítulo quinto estudia dos autores anglosajones: Hart y Dworkin. La teoría de Hart es vista por el autor como una teoría positivista (p. 126). En cuanto a Dworkin, se explica el alcance de la distinción sostenida por este entre principios y normas, y las consecuencias de tal planteamiento.

El capítulo sexto está dedicado a la aplicación e interpretación del Derecho. Toda teoría de la interpretación supone según el autor, una teoría del conocimiento y una teoría del fenómeno a interpretar. Posteriormente se pasa al análisis de las teorías de la interpretación provenientes del historicismo, del conceptualismo, de la jurisprudencia de intereses, del movimiento del Derecho libre, de la teoría pura, de la tópica y hermenéutica y del uso alternativo del Derecho. La conclusión final de este capítulo es la tesis de que la interpretación es una tarea claramente ideológica (p. 193 y ss.).

El libro concluye con un capitulo que bajo el título Derecho, sociedad y revolución se plantea problemas como el de la autonomía o no autonomía del Derecho respecto a la sociedad, el concepto de revolución y la valoración ética del fenómeno revolucionario.

ciación de la Cátedra Francisco Suárez que, además, quedará definitivamente adscrita a aquélla, separándose de la Facultad de Letras.

En 1960, Agustín de Asís preparó un proyecto de nuevo marco legal para la Cátedra Francisco Suárez, que no llegó a aprobarse por el ministerio, en el que entre otras cosas se proponía la edición de un boletín (que acabaría por ser los «Anales de la Cátedra Francisco Suárez»). Durante el período de dirección de Agustín de Asís las actividades se centraron en la organización de ciclos de conferencias y cursos de teología, así como en la edición de textos clásicos, de monografías y de los «Anales».

En relación con los «Anales de la Cátedra Francisco Suárez» pueden distinguirse dos etapas: una, desde su nacimiento en 1960 hasta 1966; y otra, desde 1967, en que se incorpora el profesor López Calera, hasta hoy. En la primera etapa, la revista mantiene su fidelidad a los objetivos fundacionales de la Cátedra (estudio de los clásicos y difusión de la filosofía perenne o escolástica). En la segunda, comienza un cambio de orientación que progresivamente irá haciendo de la revista una publicación «más abierta ideológicamente y con indudable prestigio científico»; prueba de ello pueden ser los temas monográficos tratados en la misma («Hegel», «Derecho y Estado», «El pensamiento jurídico español del siglo XIX». «Derechos humanos», «Derecho y vida judicial», «Hobbes», «Derecho y soberanía popular», «Razón, práctica, derecho e ideología» y «Savigny y la ciencia jurídica del siglo XIX») así como las colaboraciones de autores de las más diversas ideologías.

(J. A. R.)

esta parcela del saber humano- en cuatro grandes sectores: ontología jurídica (conocimiento del ente jurídico); sociologia jurídica (manifestaciones concretas del ente jurídico); lógica jurídica (criterios formales de conocimiento) y Derecho natural (justificación y fundamentación última de lo jurídico positivo). Finalmente, analizada la significación de la Filosofía del Derecho en la consideración total y plena de lo jurídico y se plantea en relación con cada uno de los sectores el problema metodológico que, en lo que concierne al último de ellos sólo puede encontrar solución con el método escolástico; además, el autor subraya que en el Derecho natural afloran más que en ninguna otra parcela iusfilosófica las condiciones del sincretismo metodológico, funcionando así como mediador entre los sectores ya aludidos de la especulación jurídica. 
LOSANO, Mario G.

La teoría pura del Derecho: del logicismo al irracionalismo. (Trad. de Juan Ruiz Manero).

Doxa, Alicante, n. ${ }^{\circ} 2,1985$, págs. 55-85.

El autor, tras caracterizar a la teoría pura del Derecho como un opus perpetuum tanto en el sentido de monumentum aere perennius como en el de perpetuum mobile, delimita el objeto de su ensayo diciendo que no es otro que el de «especificar, en primer lugar, de qué forma la Teoría general de las normas desarrolla trabajos kelsianos anteriores señalando, después, sintéticamente, las ideas nuevas contenidas en este libro y las consecuencias que las mismas implican para la teoría pura del Derecho que hoy ya podemos llamar clásica y que encuentra su expresión en La teoría pura del Derecho de 1960». Así, mi aportación - nos dirá Losano- "se presenta no como una valoración crítica de la teoría pura del Derecho, sino como una contribución históricofilosófica sobre su formación".

En la primera parte, pues, Las relaciones entre Derecho y Lógica en el último Kelsen, Losano traza la evolución de estas relaciones que va desde la aceptación de la aplicabilidad de los principios lógicos al Derecho en la segunda edición de la Teoría pura del Derecho a la aceptación del irracionalismo jurídico en la Teoría general de las normas. Así, para seguir las etapas de este cambio Losano examina el problema de las relaciones entre Derecho y lógica en la Reine Rechtslehre de 1960, para pasar después al análisis de algunos escritos posteriores (Derogation de 1962, la correspondencia mantenida con U. Klug entre 1959 y 1965 y Recht und Logik de 1965) en los que Kelsen completó la revisión de sus posiciones sobre dichas relaciones, «llegando a lo que Weinberger denomina 'su nuevo credo lógico-metodológico'».

En la segunda parte, La última obra de Kelsen, tras determinar la fecha de maduración de la Teoría general de las normas (en torno a 1965) y comentar las fuentes de la misma (tanto las ausencias como las presencias),

LUCAS, Javier de.

La noción de defensa y la crisis de legitimidad (¿Qué significa Defensa?).

Anuario de Filosofía del Derecho, Madrid, n. ${ }^{\circ} 2$, 1985, págs. 77-95.

En opinión del autor, el esclarecimiento y justificación de la noción de defensa es un problema previo a todo debate efectivo sobre la paz. Tras estudiar brevemente el origen de la vinculación entre las nociones de defensa y Estado, leit-motiv de una importante tradición de la filosofía política, propone la discusión de su relación con la realización de la paz, que no ha de buscarse tanto o mejor, no primordialmente, en la dimensión internacional cuanto en la situación actual de las relaciones entre privaticidad y publicidad, como ha sido puesto alguna vez de manifiesto. En ese sentido, subraya lo que denomina "mecanismo de sacralización de la defensa", a cuyo estudio dedica la mayor parte del artículo, como rasgo característico de dicha situación, apoyándose en las aportaciones de la sociología clásica (Ferguson, Spencer y, sobre todo, Durkheim) la psicología social (Freud, Fornari) o la Filosofía de la moral (Bergson), corroborando las tesis expuestas por Hegel. A través de ese examen se advierte cómo la política de defensa se presenta, de un lado, como problema esencial e indiscutible - al margen de las ideologias - y por esa razón, unida a su característica complejidad, sustraída al debate público. A ese proceso no es ajeno, en modo alguno, la correlativa militarización de la vida civil, característica de lo que se ha dado en llamar "democracia acorazada", que inevitablemente se traduce en el recorte de las libertades, como denuncia entre otros Thompson. La conclusión es que, precisamente por esta vía se pone de manifiesto una de las líneas de quiebra de la legitimidad hoy, que apunta hacia la limitación de la publicidad y, por ende, de la propia noción de soberanía popular, (base de la democracia misma, como apuntan Habermas, Offe, Bobbio), por cuanto desvirtúa o al menos incide seriamente en las condiciones del pacto y en su

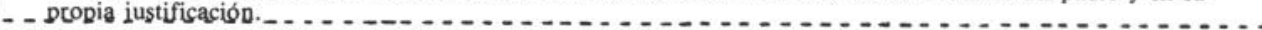

LUCAS, Javier de.

Una consecuencia de la tesis de los derechos: la desobediencia civil según $R$. Dworkin.

Doxa, Alicante, n. ${ }^{\circ} 2,1985$, págs. 197-207.

El artículo está dividido en tres partes. En la primera, La tesis de Dworkin y su repercusión en el análisis de la desobediencia civil, el autor se detiene en dos nociones centrales de la Filosofía jurídica de Dworkin: a) por un lado, la tesis "fuerte" sobre los derechos individuales, que supone que "el Derecho y el Estado no son otra cosa que instrumentos de garantía de los derechos individuales», lo cual les confiere a tales derechos el carácter de "triunfos... sobre el bienestar colectivo"; y b) por otro lado, la tesis de «la interrelación e inseparabilidad de los problemas morales y jurídicos». Todo ello llevará a que "el problema de la desobediencia civil no será tanto jurídico, sino ético, o, más exactamente, ético-político: un conflicto provocado por la situación de incertidumbre en que se encuentra el ciudadano que no puede decidir con claridad si una ley es válida y duda en acogerse a unas directrices políticas o principios, o a otros diferentes. Pero afirmar que la desobediencia civil, como cualquier otro conflicto en que entra en juego la conciencia individual de lo justo, es uno de los supuestos en que se pondría de manifiesto hasta qué punto - en el sistema que sirve de referencia a Dworkin - la validez de la ley depende de complejos problemas morales supone plantear en realidad un problema juridico y, por consiguiente, introducir otro elemento de posible confusión entre concepto y justificación del Derechom.

En la segunda parte, La desobediencia civil, el autor pone de manifiesto cómo Dworkin sitúa el concepto de desobediencia civil en relación con la existencia de un deber general de obediencia al Derecho, siempre que exista respeto a los derechos individuales (básicamente a la dignidad y a la igualdad), y cómo Dworkin se ocupa, además, de la justificación de la desobediencia en el contexto del sistema de los U.S.A. Por último, en La respuesta a la desobediencia civil, el autor se detiene en la idea de que Dworkin parece aceptar como una exigencia 
Losano entra a analizar esta última obra siguiendo la división en tres partes propuesta por Opalek: a) Respecto de la primera parte, en la que se encuentran los temas clásicos de la teoría pura del Derecho, revisados y ordenados en función de la construcción de una teoría general de las normas, Losano se centra en el concepto de norma, el dualismo ser-deber ser y el acto de voluntad. b) En relación con la segunda parte, cuyo tema central es la afirmación de la imposibilidad del paralelismo entre la verdad de una proposición y la validez de una norma, Losano retorna la correspondencia de Kelsen con Klug y muestra como los conceptos de verdad, axioma y proposición normativa son puntos de discrepancia entre ambos autores. Y $\mathrm{c}$ ) respecto de la tercera parte, cuyos puntos nodales son la negación de la aplicabilidad a las normas del principio de no contradicción y del principio de inferencia, Losano muestra como Kelsen abandona por completo el logicismo de la teoría pura del Derecho y reconduce la totalidad del ámbito normativo exclusivamente a la voluntad.

A continuación, Losano distingue tres fases (interconectadas entre sí, hasta el punto de poder hablar de un único opus perpetuum) en la evolución del pensamiento de Kelsen, al tiempo que reseña algunas de las innovaciones más importantes de su última etapa. Por fin, Losano dedica las líneas finales del artículo a preguntarse sobre la fecundidad de emprender investigaciones en busca del verdadero Kelsen. Su respuesta es clara: «Al reflexionar sobre la imponente extensión de su obra, es inevitable la comparación con la arquitectura. ¿Tiene sentido preguntarse cuál es la verdadera iglesia de Santa Sofía, catedral convertida en mezquita, o el verdadero templo de Córdoba, mezquita transformada en catedral? Sería bastante discutible el mérito de una operación... que recondujera a cada una de ellas a su estructura original: no todo lo acaecido antes es necesariamente mejor; ni lo es necesariamente cuanto ha sucedido después. En ambos casos, la mezquita es tan verdadera como la catedral: ésta es su realidad, heterogénea y contradictoria».

(J. A. R.)

básica de todo acto de desobediencia civil la aceptación del castigo. Sin embargo, en opinión de Javier de Lucas, «en la medida en que asegura que quien desobedece no puede ser equiparado en modo alguno a un criminal -con el significativo límite de la violencia-, y a la vista de que la sociedad no se desmorona si tolera alguna desobediencia, que lo que diferencia a la democracia es precisamente, como se ha subrayado con frecuencia, el grado de disidencia que son capaces de albergar y su capacidad para responder por otras vías que el recurso de la fuerza -la eliminación de quien desobedece-; Dworkin encuentra razones para absolver o adoptar una posición flexible respecto al castigo de la desobediencia civil». 


\section{LUHMANN, Niklas.}

El enfoque sociológico de la teoría y práctica del derecho.

Anales de la Cátedra Francisco Suárez, Granada, n. ${ }^{2}$ 25, 1985, págs. 87-103.

En este artículo el autor se plantea el problema general de que si bien «los actores suelen ya saber por que actúan, cómo actúan y que pueden apoyar tal conocimiento en una semántica elaborada que lo oriente», la sociología tiene que «saber más de alguna manera, que los mismos actores; sea porque relativice su conocimiento como cultura, reduciéndolo a un factor entre los otros determinadores de la acción; sea porque se basa en una sospecha general de la motivación, no asumiendo la convicción del actuante respecto al sentido de su actuación, sino racionalizando su sentido como efecto de socialización, de privaciones o de necesidades de compensación». En este sentido, el autor nos dirá a pesar de que existen investigaciones desde diversos puntos de partida (tales como la teoría de Parsons, el estructuralismo, la técnica empírica del análisis de estructuras latentes...) no hay, todavía, «ninguna satisfactoria sociología de la teoría jurídica; y sin ella no puede existir tampoco ninguna sociología satisfactoria del sistema jurídico que se refleje en esa teoría». A partir de este planteamiento, el autor se propone mostrar como «los nuevos desarrollos relativos a una teoría de sistemas autorreferentes abren nuevas perspectivas para esta problemática», centrándose, sobre todo, en la teoría de sistemas «autopoiéticos» (que se producen por medios propios), en los «second order cybernetics» (que apuntan a la unión de autorreferencia y observación) y en las investigaciones que consideran a las paradojas de la autorreferencia como incluidas en el cálculo lógico o como hechos en sistemas empíricos.

(J. A. R.)

MANCINI, Pasquale Stanislao.

Sobre la nacionalidad. (Presentación de Antonio-Enrique Pérez Luño y Trad. de Manuel Carrera).

Ed. Tecnos, Madrid, 1985.

En el pensamiento filosófico-jurídico y político italiano del siglo XIX ocupa un puesto relevante la personalidad y la obra de Mancini. De entre sus escritos, revisten especial interés sus ensayos sobre la nacionalidad, que ahora han aparecido traducidos al castellano en este volumen. La traducción se halla precedida por un cuidado estudio del profesor Pérez Luño en el que tras trazar una sucinta, pero completa, semblanza biográfica de Mancini, expone los aspectos más interesantes de su concepción filosófico-jurídica y de su doctrina sobre el principio de la nacionalidad.

La filosofía jurídica de Mancini aparece, según el análisis de Pérez Luño, muy influenciada por el eclecticismo de Victor Cousin, así como por el saintsimonismo francés, que Mancini asimila a través de Pellegrino Rossi. Son también notables en su pensamiento los estímulos doctrinales de Vico, Romagnosi, Gioberti y Mazzini. A partir de estas premisas teóricas, que inspiran su doctrina, concibe el Derecho como síntesis de la razón y la sensación, de lo real con lo ideal, del conocimiento a priori con las experiencias, del principio de la virtud y del de la felicidad. Todo ello tiene como principal finalidad el bien de la persona humana, considerada como producto de una combinación del elemento moral con el sensible.

La gran aportación teórica de Mancini, la que le consagró como una figura del pensamiento jurídico y político del siglo XIX y como fundador de la Escuela italiana del Derecho Internacional, ha sido sin duda su concepción de la nacionalidad es, ante todo, un valor moral, una realidad axiológica que surge de lavoluntad de autonomía y libertad que lo informan y que trasciende la mera angostura empírica de las circunstancias territoriales, étnicas olingüísticas.

(C. G. T.)

\section{MÁRQUEZ GONZÁLEZ, José Antonio.}

Hart y Kelsen: regla de reconocimiento y norma básica.

Persona y Derecho, Pamplona, n. ${ }^{\circ} 12,1985$, págs. 163-188.

En este artículo se realiza una comparación de las teorías sobre la validez de las normas jurídicas sostenidas por Kelsen y Hart. El autor, examina las diferencias que existen entre ambas teorías cuyo centro se encuentra, respectivamente, en la norma básica y en la regla de reconocimiento; la primera, es la clave de una moda formal del Derecho en la que no se admite intromisiones de otras disciplinas que no sean las jurídicas, la segunda, por el contrario, descansa en un fenómeno sociológico cual es la aceptación social. Tenemos así dos concepciones distintas sobre la validez de las normas y, por tanto, dos comprensiones diferentes del Derecho. Sin embargo, a juicio del autor, la cosa no es tan simple como puede parecer a primera vista. Para él, la teoría pura del Derecho no esta exenta de factidad, sobre todo, cuando Kelsen expone las relaciones entre la validez y la efiçcia. Para Kelsen existida un nexo entre la eficacia del ordenamiento jurídico y el nacimiento de la norma básica en el sentido jurídico positivo, lo cual no impide que Kelsen siga sosteniendo que validez y eficacia sean dos categorías distintas. En definitiva, norma básica y regla de reconocimiento cumplen funciones ideáticas, pero tienen sin embargo, un distinto estatuto ontológico: mientras la norma básica a una categoría lógico-trascendental perteneciente al mundo del deber ser, la regla de reconocimiento sería una categoría sociológica basada en el fenómeno de la aceptación social. A pesar de esta divergencia radical, el autor señala en las conclusiones que Kelsen acepta un «cierto grado de factidad en el nacimiento de la norma básica, factidad que vincula al concepto de eficacia del orden jurídico, pero sin llegar a constituir nunca la razón de su validez, sino simple condición para su procedencia».

(F. L. R.) 
La teoría de la justicia en John Rawls (prólogo de J. J. Gil Cremades).

Ed. Centro de Estudios Constitucionales (Colección El Derecho y la Justicia, n. ${ }^{\circ}$ 4). Madrid, 1985, 210 págs.

El libro se estructura en cuatro capítulos. En el primero, Introducción, el autor se centra principalmente en el contexto intelectual e histórico de Rawls. El autor parte de la constatación de que la ética anglosajona de la primera mitad del siglo se halla «bajo el signo de Hume»: todo conocimiento sustantivo deriva de la experiencia sensible; las aserciones morales no entran en el campo de lo verificable; y en la filosofía moral se impone el emotivismo. «Sólo el utilitarismo con su razón instrumental, su neutralidad frente a los deseos de todos... podría ser una ética aceptable. Esta etapa se ha caracterizado sobre todo por la discusión en tomo al utilitarismo, que también fue a su manera la ética de Hume» (pág. 3). A partir de los años cincuenta se producirán intentos de superación del emotivismo invocando en ocasiones motivos kantianos (universalización) y en otras criterios menos formales. Sin embargo, no puede decirse que se avanzara demasiado en lo que es el tema clave, razón y ética, donde esta implicada la misma identidad de la razón. En cuanto al contexto histórico, los años sesenta fueron en Estados Unidos un período de intensa politización y conflictividad social (el problema racial y los derechos civiles, la guerra del Vietnam, la contestación estudiantil... ). «En este ambiente, problemas como la justicia distributiva, el poder político... adquirieron dimensiones muy vivas y hay especial necesidad de una teoría de la justicia» (pág. 5).

En el segundo capítulo, Los presupuestos de la teoría, el autor se propone una progresiva aproximación a la visión de Rawls a partir de un conjunto de cuestiona clave que constituyen los presupuestos de una teoría de la justicia: a) el modo de plantearse el problema de la justicia de manera totalizadora (¿cómo debe ser una sociedad para que sea justa??) operando su restauración, «su recuperación en su carácter total frente a los análi-

\section{MONTORO BALLESTEROS, Alberto.}

\section{Notas sobre el razonamiento jurídico y la posibilidad, significación y límites de la lógica jurídico.}

Persona y Derecho, Pamplona, n. ${ }^{\circ}$ 12, 1985, págs. 67-109.

En este artículo, se analiza el ya clásico problema de la posibilidad de aplicación de la lógica al Derecho. El problema previo que se trata de dilucidar es qué se entiende por lógica y, más concretamente, por lógica jurídica. Tomando como punto de partida la obra aristotélica, el autor analiza el alcance de los distintos modos de razonamiento estudiados por Aristóteles: Analítico, Retórico, Dialéctico y Tópico; examinando su significado y función.

A su juicio, el problema crucial de la vida jurídica es la determinación de lo justo; para ello hay dos medios: a) uno extra-racional, propio de los Derechos primitivos y, b) otro racional, vinculado al proceso de secularización de la jurisprudencia; que entiende la creación y aplicación del Derecho como obra exclusiva del razonamiento humano. Ahora bien, si el derecho es obra de la razón humana jes esta razón la misma que opera en las matemáticas y en las ciencias empíricas, o es una razón diferentel Ante este dilema hay dos soluciones, según el autor, en las que subyacen concepciones distintas y heterogéneas de lo que es el Derecho. La primera se caracteriza por una «mentalidad racionalista y una concepción legalista del Derecho» como la defendida por el iusnaturalismo racionalista, la escuela de la exégesis, la jurisprudencia de conceptos y, modernamente por concepciones como las de Von Wright, Ross y García Maynez. La segunda solución («mentalidad empírico historicista y concepción no legalista del Derecho») tiene unos antecedentes que se remontan a Aristóteles y a Cicerón, encuentra una elaboración más depurada en la obra de G. Vico; otros de sus representantes genuinos son la jurisprudencia de intereses, el sociologismo jurídico y el realismo americano, y. contemporáneamente, Esser, - Perelman, Recaséns, Viehweg yVilley, entre otros. El autor analiza con especial detenimiento los planteamien-

\section{MONTOROBALLESTEROS, Alberto.}

\section{Reflexiones sobre el problema actual de la guerra y de la paz internacional.}

Anuario de Filosofía del Derecho, Madrid, n. 2 2, 1985, págs. 163-184.

I. Desde la Antigüedad hasta nuestros días se han desarrollado en la Filosofía de la historia dos líneas de pensamiento acerca de la guerra y la paz. Para una de ellas -representada, entre otros, por Heráclito, Maquiavelo o Hegel y por la actitud de los Estados totalitarios, sean fascistas o marxistas- la guerra es el medio natural del hombre y un factor de progreso moral, cívico y técnico. Para la otra -representada principalmente por el Cristianismo- la paz constituye el valor supremo en cuanto que no es sólo la ausencia de guerra, sino la «síntesis de la suma de todos los bienes» fundamentada en la justicia.

II. La situación política internacional en la que se plantea hoy el problema de la paz y la guerra se caracteriza por la influencia en su configuración de tres importantes fenómenos históricos: a) «El proceso de liquidación de la segunda Guerra Mundial» y sus consecuencias (división de Europa en «zonas de influencia», la «guerra fría», la creación de bloques militares, la política de «coexistencia pacifica»,...). b) «El proceso de emancipación política del llamado Tercer Mundo». c) «La celebración del Concilio Vaticano II».

III. A pesar de sus deseos de paz, el hombre no puede suprimir la guerra; ello es así, en opinión del autor, porque no existe «una autoridad pública universal reconocida por todos con poder eficaz para garantizar la seguridad, el cumplimiento de la justicia y el respeto de los derechos» (tesis del supraestado) y porque el hombre «lleva dentro de sí mismo, junto al deseo de paz, el conflicto, la contradicción y la guerra». Tampoco parece posible limitarla, regularla. Para la teoría de la guerra justa, la moral y el Derecho deben establecer los cauces para que la guerra sea una institución adecuada para realizar la justicia; pero difícilmente puede hoy hablarse 
ticos, su rango de primer problema» (pág. 15); b) la concepción del hombre, los rasgos de la antropología de Rawls; c) su visión de la sociedad, las notas de su sociología; d) la crítica a las teorías de ética normativa (el perfeccionismo, el utilitarismo, el intuicionismo, etc.).

En el capítulo tercero, la teoría, el autor procede a analizar críticamente la teoría de Rawls partiendo de las actitudes metodológicas, pasando por todos los puntos nodales de la misma (la posición originaria) y concluye con los principios de justicia.

Por último, el capítulo cuarto, Consideraciones críticas, recapitula los «momentos de tensión» dentro de la teoría de Rawls, de los que pueden destacarse los siguientes: a) La circularidad en la argumentación; las premisas (presupuestos antropológicos y sociológicos, metodología) soportan realmente el peso de la teoría y constituyen una «problemática ideología... que apenas esta razonada sino casi siempre dada por supuesta». . b) La insistencia en presentar su pensamiento como un esquema de razonamiento deductivo cuando en realidad está actuando en su conjunto como una pieza de argumentación retórica o persuasiva. c) La aceptación no especialmente justificada del mercado como forma más eficaz de distribución y la falta de una discusión seria con el pensamientomarxista. d) La ambivivalencia y ambigüedạd de su pretendida superación del militarismo, pues «es posible entender rasgos decisivos de la posición originaria como una versión del militarismo de la regla». e) La combinación de elementos procedentes de la sociobiología (fundamento biológico y evolucionista del sentido de la justicia) con pretensiones de ser un teórico de la estirpe de Kant (el puro reino moral de la posiciónoriginaria).

(J. A. R.)

tos de Perelman y Villey; para ellos, el procedimiento a través del que se determina lo que corresponde a cada uno no puede ser objeto de ciencia (en sentido fuerte) sino de prudencia, en la que están implicados elementos lógico-sistematicosypragmáticos.

Kalinowski ocuparla, a su juicio, una posición intermedia entre las dos opciones mencionadas, pues, para él, el razonamiento jurídico tiene una naturaleza compleja en la que se entrelazan elementos de significación lógica (formal), paralógica y extralógica.

En conclusión, para el autor la lógica jurídica comprendería no sólo la lógica deóntica, sino también la Dialécti$\mathrm{ca}$, la Retórica y la Tópica jurídica, que tendrían estructuras diferentes tanto por la forma en que trabajan como por el contenido y la distinta finalidad a que obedecen.

(F. L. R.)

de guerra justa -ni siquiera cuando es defensiva- ante el desmesurado potencial destructivo de las nuevas armas y la imposibilidad de establecer límites geográficos al conflicto (además de que la teoría de la guerra justa se basa en una falaz analogía entre la guerra y el procedimiento judicial). Frente a esta situación, el pacifismo no parece solución adecuada ni realista: el pacifismo antepone la paz al resto de valores, por lo que se opone a todo tipo de violencia y en todo momento, así como al rearme, lo que es ciertamente elogiable en el ámbito personal pero implica en el social y político la imposición al Estado de una postura sumisa e indefensa (por ello el desarme ha de ser recíproco; quien defiende un desarme unilateral es un pacifista ingenuo o un falso pacifista que sólo busca debilitar a los demás). La solución que propone el autor al problema de la guerra es la de su prevención mediante una política de disuasión, acompañada de un proceso de «convivencia» y «socialización» entre los Estados que desplace la paz armada (que realmente no es paz) por la paz verdadera; de todas formas es preciso tener consciencia de que la paz «es un valor moral que el hombre solo podrá alcanzar -junto con su esfuerzo, con su trabajo- con el auxilio de la gracia de Dios y el concurso de su Providencia».

(D. G. L.) 


\section{MONTORO BALLESTEROS, Alberto.}

Sobre el problema de la legitimación democrática del Derecho y del Estado.

Revista de Estudios Políticos, Madrid, n. ${ }^{\circ} 44,1985$, págs. 137-166.

Este artículo es una réplica del autor a los planteamientos sostenidos por Elías Díaz en su libro De la maldad estatal y la soberanía popular, a propósito del libro de A. Montoro Ballesteros Razones y límites de la legitimación democrática del Derecho. A juicio del autor, existirían tres errores de base en el planteamiento de Elías Díaz: 1) Atribuir al autor la tesis de la identidad entre Derecho y justicia, cuando en realidad distingue entre una «validez dogmática» y una «legitimidad o validez ética»; 2) Imputarle una concepción absolutista de la justicia cuando, siguiendo la tradición iusnaturalista, ha sostenido que la concreción de la justicia en el Derecho no es algo dado de una manera definitiva sino un producto histórico y problemático; 3) Acusarle de incurrir en la «falacia naturalista», cuando en realidad, partiendo de supuestos suarecianos, ha distinguido entre la naturaleza misma como fundamento de la conveniencia o inconveniencia respecto a ella de las acciones humanas, $\mathrm{y}$ «una fuerza que hay en esa naturaleza para discernir entre las operaciones convenientes e inconvenientes con esa naturaleza, a la cual llamamos razon natural».

Ante el dilema de la existencia de una eventual contradicción entre el iusnaturalismo y la democracia afirma que en la tradición iusnaturalista, en la que se integra el autor, a) el Estado ha de tener como fin el bien común, b) el Derecho natural debe actuar como límite de la soberanía popular, pues «no existe contradicción alguna en afirmar, por un lado, que la democracia constituye el método mas adecuado para la búsqueda y elaboración del Derecho justo, y decir, por otro lado, que la democracia legítima a quien manda, pero no, necesariamente y en todo caso lo que se manda».

\section{OLLERO, Andres.}

\section{Positividad jurídica e historicidad del Derecho.}

Anuario de Filosofía del Derecho, Madrid, n. 2, 1985. págs. 285-296.

El autor parte de un análisis que le permita valorar «en qué medida la opción por lo 'positivo' contribuye realmente a dar cuenta de la historicidad del Derecho» y, a tal efecto, examina la opción por la positividad desde una triple perspectiva: a) La opción por la positividad responde en muchos casos al afán de garantizar la $\mathrm{ra}$ cionalidad científica. El ámbito propio de una jurisprudencia racional exige distinguir el derecho positivo, o puesto, de otros objetos conexos, y esta relación racionalidad-positividad empuja al normativismo. b) Desde una perspectiva práctica, la opción por la positividad jurídica refleja a su vez una atención primordial al logro de la seguridad en la convivencia social: el conocimiento, bien delimitado, del alcance del Derecho facilita una fiable previsión de sus consecuencias. Ello empuja a la no-retroactividad de las normas jurídicas. c) Tras la opción por la positividad jurídica late, también, una determinada respuesta al problema de la legitimación política del Derecho. Se rechaza con ella toda instancia de legitimación que trascienda al derecho puesto, afirmándose la soberanía política en un ámbito secularizado. Ello empuja ahora al voluntarismo jurídico.

Pues bien, si irracionalidad, seguridad y legitimación son los frutos esperados de la positividad jurídica, y normativismo teórico-jurídico, no retroactividad de las normas y esquema voluntarista de legitimación parecen ser sus corolarios obligados, el autor se propone ver cómo «enfoques sucesivos de la positividad jurídica, al ir intentando plasmar este programa, se han visto forzados a revisar algunos de sus aspectos ante la presión de determinados factores, expresivos precisamente de la historicidad del Derecho». Y así, a partir de este planteamiento, el autor se detiene en el análisis de los siguientes temas: la «positividad instantánea» del legalismo; normati-

\section{OSUNA FERNÁNDEZ-LARGO, Antonio.}

\section{El derecho de la paz en la Escuela Epañola de Derecho Natural.}

Anuario de Filosofía del Derecho, Madrid, n. ${ }^{\circ}$ 2, 1985, págs. 195-205.

La contribución al Derecho de la paz realizada por la Escuela Española de Derecho Natural, con la determinación de las condiciones que una guerra ha de reunir para que sea justa, es refutada por algunos tratadistas modernos basándose en que tal doctrina dio un realce inmoderado ala licitud de la guerra frente a otras posturas del tiempo defensoras del pacifismo, sirvió de cobertura ideológica para justificar las guerras de religion, y traición el pensamiento de los primeros cristianos acerca de la naturaleza intrínsecamente perversa de la guerra. Es opinión del autor, sin embargo, que la lectura y el estudio directo de los pensadores iusnaturalistas del siglo XVI hace desvanecer estas objeciones. Tomando como punto de partida la consideración de «la paz como motivo obligado de la guerra justa en la teoría agustiniano-tomista», analiza las tesis de Francisco de Vitoria, Diego de Covarrubias y Francisco Suárez estimándolas encuadradas en un contexto más propiamente ético y jurídico que teológico.

Para Vitoria finis belli est pax. La paz mundial es un derecho natural primario en la comunidad universal, un fin al que la guerra queda condicionada para su realización. Pero la sola justificación de la guerra como un derecho de gentes (prevalentemente positivo, histórico y mudable) hace que esta tenga una legitimación sometida a la evolución de la vida de los pueblos. Diego de Covarrubias precisó que «la guerra ha de ser sometida al Derecho y a las normas para que no estalle en odios y males sin cuento ni se convierta en instrumento de los más fuertes». Los supuestos en que la guerra es justa se reducen en este autora los casos de la defensa legítima y de la reparación del daño causado, si bien admite la aplicación de la potestad coactiva del poder político 
El autor, a continuación, trata de explicitar lo que ha denominado «régimen mixto» que no es idéntico a la democracia pero sí análogo a ella. El tema del «régimen mixto» se reconduce a la dialéctica mayoría/minoría en el proceso de elaboración del Derecho y en el de adopción de decisiones políticas; en todo caso, en el «régimen mixto» hay tareas que competen a una sola persona (principio monárquico), a varias personas cualificadas (principio aristocrático), y a todo el pueblo (principio democrático); ejemplo de este último procedimiento sería el mecanismo articulado para la elaboración de la Constitución española de 1978.

Concluye el artículo con unas reflexiones en torno al dilema democracia-dictadura; concretamente, la tesis central del autor en este punto es la dictadura se justifica «en circunstancias excepcionales en las que el desenvolvimiento de la vida democrática no es materialmente posible, y en virtud del principio de 'legitimidad de ejercicio', el poder legítimo, la autoridad, la posee quien es capaz de crear, dentro de los límites y condicionamientos que toda situación extraordinaria o excepcional comporta, el mínimum posible de orden social, político y económico necesario para el mayor desenvolvimiento de la vida humana. Ello significa, dicho lisa y llanamente, sin ningún género de eufemismos, que en determinadas circunstancias la dictadura -dictadura que no es lícito identificar con tiranía- es el único modo fecundo, civilizado y legítimo de ejercitar el poder».

(F. L. R.)

vismo judicialista y «positividad en cadena»; Una constatación realista: la «positividad sobrevenida»; la dimensión histórica de la positividad como «proceso de realización» del Derecho.

(J. A. R.)

(que no la considera guerra en rigor) en nombre de la comunidad humana. «La comunidad universal representa en la teoría de la guerra justa el poder supremo, por cuyo mandato se procede al castigo del pueblo o de los soberanos causantes del daño inferido». Las guerras defensivas y vindicativas son, en la concepción de Francisco Suárez, las únicas justas, fundándose en el incuestionable derecho a la paz de la comunidad humana. Las calamidades de la guerra son preferibles a los daños causados por la injusticia, porque la guerra persigue la instauración de una paz justa que está basada en los bienes que le son consustanciales: vida de un pueblo, libertad, independencia, identidad cultural y humana, disfrute de derechos civiles y políticos..

En los teóricos de la Escuela Española de Derecho Natural «está suficientemente explicitada la necesidad de buscar una autoridad válida para toda la sociedad humana, que pueda convertirse en tribunal para resarcir las injusticias de unos pueblos contra otros, sin el recurso al castigo bélico».

En fin, el artículo concluye afirmando que la guerra justa es un interludio inarmónico, pero necesario, para reparar la injusticia e instaurar la paz, único derecho natural inmutable.

(A. D. P.) 
PATTARO, Enrico.

La razón en el Derecho. Comentario a Norberto Bobbio. (Trad. de Manuel Atienza).

Doxa, Alicante, n. ${ }^{\circ} 2,1985$, págs. 147-152.

Basándose fundamentalmente en Aristóteles, Enrico Pattaro comenta dos puntos de la ponencia publicada en el mismo número de Doxa de Bobbio sobre la razón en el Derecho. El primero se refiere a la distinción entre razón fuerte y razón débil. Según Pattaro, Aristóteles ya recoge la distinción, correspondiéndole a la ciencia y su método deductivo la razon fuerte, y a la prudencia y su método inductivo la razón débil. En definitiva, para Pattaro, la distinción entre los dos tipos de razón no se corresponde con la de nivel de descubrimiento/nivel de aplicación, sino con la de razón científica/razón prudencial.

La segunda puntualización se refiere a la división entre contexto de descubrimiento y contexto de justificación. Según Pattaro, Bobbio corre el riesgo de confundir la razón fuerte con el contexto de descubrimiento y la razón débil con el de justificación cuando sería posible en realidad efectuar diversas combinaciones entre estos cuatro elementos, que caracterizarían hasta cuatro distintas maneras de entender la razón en el Derecho.

(A. J. M. V.)

\section{PAUL, Wolf.}

Las dos caras de la teoría jurídica marxista.

Anales de la Cátedra Francisco Suárez, Granada, n. ${ }^{\circ}$ 25, 1985, págs. 137-159.

Este artículo -en palabras del amor- «constituye un intento de inventario. En él se sostiene la tesis de que, en la historia de su desarrollo, la teoría marxista ha sufrido un cambio de paradigma, que obliga a diferenciar la concepción original fundada por Marx (epígrafe II) de la posterior 'evolución marxista-leninista'. Este doble sentido de la teoria jurídica marxista -que no siempre es externamente reconocible en la línea fronteriza que separa las interpretaciones «occidentales» de las «orientales» (epígrafe I)- obedece a razones históricas y sistemáticas. Tal ambigüedad es atribuible, en primer lugar, a las reelaboraciones hechas por los marxistas del socialismo real tras la revolución de Octubre (epígrafes IV y V), pero puede ser asociada, cum grano salis, a una aporía inherente a la misma concepción marxiana (epígrafe III)».

(J. A. R.)

\section{PAULSON, Stanley L.}

El período posterior a 1960 de Kelsen: ¿Ruptura o continuidad? (Trad. de Josep Aguiló Regla).

Doxa, Alicante, n. ${ }^{\circ}$ 2, 1985, págs. 153-157.

En este breve artículo, Paulson trata de demostrar el error en el que incurren los autores (como Ota Weinberger) que pretenden ver en la obra de Kelsen dos etapas perfectamente diferenciadas y acotadas en un período anterior y otro posterior a 1960. En su lugar, Paulson propone una evolución que comprendería cuatro o cinco etapas, justificando esta idea en el alejamiento que Kelsen inicia, ya desde 1938, del concepto kantiano de causalidad, y en el creciente escepticismo de dicho autor sobre la categoría de imputación normativa, perceptible en obras anteriores a 1960 . 
PECES BARBA, Gregorio.

Reflexiones sobre la paz.

Sistema, Madrid, n. ${ }^{\circ}$ 67, julio 1985, págs. 33 a 43.

Este artículo recoge el texto de la conferencia pronunciada por el autor en mayo de 1985 en la Sociedad de Estudios Internacionales. Toma como puntos de referencia obligados en esta materia dos clásicos: Hobbes y Kant. El análisis del Leviatán le lleva al autora plantearse el siguiente interrogante: «¡la búsqueda de la seguridad a nivel internacional puede seguir el mismo trayecto a través del pacto que condujo a la sociedad civil?» La respuesta consistirla en afirmar que a nivel racional es posible pensar que un consenso entre Estados puede dar lugar a la paz; sin embargo, este planteamiento ha resultado hasta ahora contradicho por la experiencia histórica. A propósito de Kant, el amor se centra en su opúsculo «La paz perpetua», y expresa su convencimientọ de que algunos de sus artículos preliminares relativos a la paz entre los Estados son válidos hoy como condiciones de esa paz.

Tras este recorrido queda en pie el interrogante crucial: «¿es posible la paz?» Después de negar la legitimidad del derecho a la guerra (ius ad bellum), el autor sostiene que frente a este dilema caben dos posturas igualmente afirmativas, pero distintas: a) la paz de la disuasión, equivalente a la ausencia de guerra: b) asumir la paz como un valor moral fundamental, «ésta es la respuesta de la ética de la paz, que no se basa en el equilibrio del terror, sino en la creación de condiciones para poder llegar a una organización supranacional que garantice la paz y una organización internacional más justa».

(F. L. R.)

PEIDRÓ PASTOR, Ismael.

El sentimiento de lo justo en Unamuno.

Anuario de Filosofía del Derecho, Madrid, n. ${ }^{2}$ 2, 1985, págs. 393-414.

Unamuno piensa que «nada es verdad si no está siendo verdad en nosotros»; y que la verdad nos tiene en sus manos como servidores de la misma. Su filosofía cabe encuadrarla dentro de lo que se llama la «Filosofía del corazón», en la cual saber y sentir, aunque diferenciados, son estados mentales del hombre. Con razón, pues, el que fuera Rector de Salamanca, se preguntaba: «La verdad, ¿se vive o se comprende? El deseó vivirla. De ahí su afirmación contra Descartes: «Homo sum, ergo cogito; cogito, ut sim Michael Unamuno».

Desde esta perspectiva filosófica enfocó el tema de la personalidad humana y la relación entre persona y sociedad; y entendió la conciencia de nuestra personalidad como «una fusión del saber, el sentir y el querer». El problema para el hombre es acertar en el modo de hacer esa fusión; él indica uno: «el camino derecho es ir por la práctica a la teoría». Subraya, además, el carácter individualista del español y su «gran pobreza de personalidad», lo cual explica su tendencia al «cantonalismo», a «querer destacarse sobre los demás», y su «culto al dogmatismo que corroe».

Mantiene una actitud «antinomista» respecto del Derecho, porque es partidario de «la ley viva e interna procedente de la propia conciencia», pues «quien abriga en su corazón esta ley, esta por encima de la dictada por los hombres». Considera el derecho a la vida como el más fundamental, porque «yo siento, al igual que mis hermanos, que he venido a realizarme, a vivir». Para esto es imprescindible el derecho de libertad, pero subordinado a la verdad moral, «camino para llegar a la verdad lógica»; y subordinado también al bien común. Aquí radica la posibilidad humana de sentir lo justo.

\section{PÉREZ LUÑO, Antonio-Enrique.}

La paz como valor constitucional.

Anuario de Filosofía del Derecho, Madrid, n. ${ }^{\circ} 2$, 1985, págs. 125-132.

El profesor Pérez Luño plantea en este trabajo una doble cuestión: a) si la paz puede considerarse un valor fundamental (Grundwert) de la Constitución española de 1978; b) de ser así, cual sería su fuerza normativa. Respecto a lo primero, el amor entiende que de una interpretación sistemática y teleológica de nuestra Constitución, en base a su Preámbulo y a los artículos 10.1 y 63.3, así como 93 y siguientes, se desprende la opción inequívoca de nuestra Ley de leyes en favor de la paz. La Constitución española de 1978 puede concebirse, por tanto, como pacifista, en cuanto no supone la defensa de una paz cualquiera, que pudiera basarse en el dominio o en el temor, sino que considera la paz como un valor, cimentado en la decisión consciente del constituyente dirigida hacia el fortalecimiento de unas relaciones de cooperación pacífica entre todos los pueblos de la tierra. En lo concerniente a la fuerza normativa del valor constitucional de la paz, se sostiene en este artículo su triple incidencia como: a) fundamento del conjunto de normas e instituciones a partir de la paz social en el plano interno, y en el fortalecimiento de las relaciones pacíficas de cooperación en el externo; b) orientación de la interpretación normativa hacia soluciones que fomenten la paz social, así como toda nuestra política internacional en el sentido de un decidido pacifismo; y c) crítica de cualquier disposición normativa o actividad de los poderes públicos que menoscabe la paz social o ponga en peligro la paz internacional, así como la consiguiente prohibición de aquellos comportamientos de los particulares atentatorios contra la paz social (tales como el ejercicio abusivo o antisocial de los derechos...) o que entrañen una infravaloración de la par internacional (propaganda de doctrinas belicistas...).

(C. G. T.) 
Este sentimiento lo desarrolla a través de las virtudes de la fe, de la esperanza y de la caridad. Respecto a esta última, distingue el sentimiento de compasión, originado «en las entrañas del que sufre viendo sufrir»; y el intelectivo que «brota de la indignación que produce ver sufrir a unos, mientras otros gozan»; «hijo de la ternura aquél, de la rectitud éste». Por eso unas veces brota el sentimiento de justicia del de caridad y otras, éste de aquél. Pero siempre, «los sentimientos son pensamientos en conmoción», Basa la solidaridad en el sentimiento de lo justo. De ahí su rotunda afirmación: «Cuanto más soy yo mismo, más soy de los demás».

Dentro de su evidente posición «existencialista» destaca su gran atención al tema de la «dignidad de la persona humana», distinguiendo en ella su «lado finito y externo» de su aspecto «infinito e interno», tema abordado también por Sergio Cotta en nuestros días, en libro reciente. 
PÉREZ LUÑO, Antonio-Enrique.

New Technology and Informatics in Free Society.

Informatica e diritto, Florencia, septiembre-diciembre 1984, págs. 41-50.

En este trabajo se aborda la organización de la sociedad en la era de la telemática. Partiendo de las pesimistas previsiones de George Orwell avanzadas en su famosa obra 1984, se comprueba el cumplimiento de su profecía en la sociedad tecnológica actual, si bien Pérez Luño entiende que, por fortuna, no se han confirmado, al menos en gran parte, los terribles presagios anticipados por Orwell. Pero ello no implica que la reflexión orwelliana sobre el riesgo que subyace a determinados empleos de la tecnología haya perdido su sentido, quedando obsoleta. Lo que ocurre es que la lectura de su mensaje conviene hacerla mas en clave de advertencia que de profecía. Sigue vigente de la obra de Orwell su llamada de atención sobre las amenazas que para el futuro de la humanidad pueden derivarse de un desarrollo tecnológico puesto al servicio de una dictadura totalitaria. De ahí que una consideración coherente de esa advertencia deba impulsar a establecer un nexo necesario de continuidad entre el reforzamiento de los derechos humanos, la participación democrática y el desarrollo tecnológico.

Se enjuicia, a continuación, el tema de la denominada «contaminación de las libertades» en la sociedad tecnológica actual. Se exponen aquí algunos de los principales supuestos de atentado a las libertades públicas y a los derechos fundamentales perpetrados a partir de utilizaciones abusivas de la tecnología informática. En especial, se analizan los peligros que desde el punto de vista del control social plantean las técnicas de ficheros cruzados, así como otras amenazas a la privacidad de los datos de carácter personal.

El artículo concluye con la defensa de una opción racional y crítica frente al progreso tecnológico. Dicha actitud debe plantearse como una alternativa frente a las posiciones «apocalípticas» 0 «integradas», es decir, frente

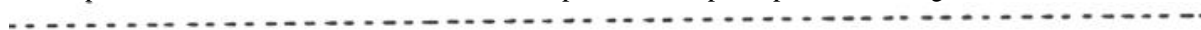

\section{PÉREZ LUÑO, Antonio-Enrique.}

Notas sobre filosofía jurídico-político de Juan Ginés de Sepúlveda. En Estudios de Filosofía del Derecho y Ciencia Jurídica en memoria y homenaje al Catedrático D. Luis Legas y Lacambra (1906-1980).

Ed. Centro de Estudios Constitucionales \& Facultad de Derecho de la Universidad Complutense, Madrid, 1985, vol. II, págs. 233-250.

La controvertida personalidad intelectual de Juan Ginés de Sepúlveda sigue suscitando un interés no sólo doctrinal sino tambien práctico por la constante actualidad de muchos de los argumentos centrales de su obra (legitimación de la guerra y del recurso a la violencia, impugnación de la libertad e igualdad naturales del género humano, justificación del colonialismo...). Ginés de Sepúlveda, como es notorio, defendió estas tesis frente a los ideales emancipatorios, humanitarios y pacifistas de su gran rival en las controversias sobre la conquista de América, Fray Bartolomé de las Casas. En la proximidad del Quinto Centenario del Descubrimiento resulta de enorme interés la reconstrucción teórica del clima de esa importante controversia, tomando para ello como punto de referencia la reconstrucción del pensamiento de Sepúlveda y su interpretación en los aspectos más decisivos de su doctrina.

Pérez Luño ha trazado una detallada información de la bibliografía básica sobre el status quaestionis de la polémica Sepúlveda/Las Casas y, a partir de ahí, ha enjuiciado con especial atención la influencia de la etapa de formación boloñesa como colegial del Real Colegio de España en la ulterior andadura intelectual de Sepúlveda. Se presta también especial interés en esta monografía a las tesis de Ginés de Sepúlveda sobre la servidumbre natural de los indios y a la peculiar hermenéutica de la Política aristotélica, en la que Sepúlveda pretende basar su postura.

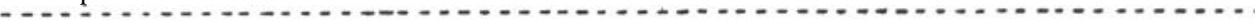

\section{PORRAS DEL CORRAL, Manuel y LEÓN SENDRA, Antonio.}

Notas para un léxico inglés-español de términos filosófico-jurídicos en la teoría de los Derechos de R. M. Dworkin.

Ed. Tipográfica Católica, Córdoba, 1985, 102 págs.

El libro esta dividido en dos partes, una Introducción y un Léxico.

En la introducción, se expone el objetivo del trabajo: «ampliar los hallazgos actuales en el campo de la lingüística aplicada, donde los estudios interdisciplinares son cada día más frecuentes; de ahí que estas notas pretendan ofrecer un esbozo de lo que en su día ha de constituir el léxico inglés-español que nos hemos propuesto elaborar, en el que a través del análisis de la terminología dworkiniana, pongamos a disposición de los estudiosos de su pensamiento, una herramienta útil de trabajo, que permita eliminar los obstáculos que se le puedan presentar, al facilitarle el sentido de aquellos vocablos más singulares en el ámbito filosófico jurídico». A continuación, los autores, exponen cuál es, a su juicio, la justificación de un trabajo de esta naturaleza: «El interés de confeccionar un Léxico especializado, surge de la necesidad de destacar la importancia del vocabulario en la comprensión de la lectura, en cuanto instrumento básico, para subsiguientes avances en el desarrollo científico de cualquier materia». Por lo que se refiere a la metodología empleada, los autores describen cual ha sido su modo de operar para realizar este trabajo. Partiendo de la obra de R. M. Dworkin: Los Derechos en serio, que es la obra analizada, declaran: «hemos confeccionado un millar de fichas, incluyendo la exacta situación en el texto, de aquellos términos, que a primera vista, nos han parecido de mayor interés y utilidad a nuestro propósito». «En la segunda fase, hemos seleccionado sólo aquellos vocablos que se repiten en el texto al menos tres veces. A continuación hemos analizado cada situación particular de una determinada palabra a fin de indagar en su contexto y así tratar de calibrar los diferentes matices polisémicos del equivalente castellano en idéntica situa- 
a aquellas que por rechazar o claudicar ante el fenómeno tecnológico son incapaces de comprender la multiplicidad de sus aspectos e implicaciones.

(R. G. T.)

Al trazar una valoración de conjunto del pensamiento de Sepúlveda, Pérez Luño sostiene que su actitud podría calificarse de paternalista, más que de autoritaria; la libertad sería un término ad quem a cuyo disfrute sólo podría llegarse con una fase previa de culturización, sin la cual el ejercicio de la libertad resulta ilusorio.

(C. G. T.)

ción. Finalmente, hemos presentado el trabajo de forma global, en orden alfabético de los términos elegidos y con una misma sistematización».

La segunda parte del trabajo está constituida por el Léxico propiamente dicho. Como quiera que no podemos hacer una relación detallada del mismo un ejemplo puede mostrar el modo de proceder de los autores. El adjetivo ABSTRACT, puede servirnos a estos efectos. Para los autores, este adjetivo que aparece dos veces en el texto de Dworkin, lo hace en relación con el sustantivo «right». En ambas ocasiones se refiere a un derecho, si bien la segunda vez se explicita su contenido al abarcar dos diferentes derechos: el derecho a igual tratamiento y el derecho de ser tratado como un igual. El derecho abstracto a igual consideración y respeto, es, para el autor, fundamenta) y axiomático. 
RAMOS CENTENO, Vicente.

Moral y utopía. La fundamentación de la moral en el pensamiento de E. Bloch.

Sistema, Madrid, n. ${ }^{\circ}$ 64, enero 1985, págs. 45-61.

Este artículo está dedicado a la relación entre moral y utopía en el pensamiento de E. Bloch, según este último, las aspiraciones humanas no caen en la nada, «a causa de una naturaleza carente de todo fin». Bloch defiende que «la vida humana no es de la condición de aquel náufrago de la imagen volteriana al que no se pudiera decir sino que siga nadando y nadando, pero que no hay tierra firme alguna. En Bloch no hay una desconexión entre valores y mundo, sin que podamos decir que su filosofía es un naturalismo. En Bloch hay una ética porque hay utopía, «porque el proceso universal es el mismo una función utópica, cuya sustancia es lo objetivamente posible». Pero esta posibilidad utópica, sólo se realizará en la mediación con el factor subjetivo. La nada, el infierno también son posibles». A partir de ahí, el autor prosigue la tarea de desentrañar la fundamentación de la moral en el pensamiento de Bloch y para ello se detiene en los siguientes epígrafes: Contra el círculo fatal; el origen bíblico de la idea escatológica; utopía, teología y moral; el hombre como posibilidad. La utopía como tarea ética humana: marxismo, socialismo y ética: y ipor qué Bloch?

\section{REALE, Miguel.}

Situación actual de la teoría tridimensional del derecho. (Trad. E. Nogueras).

Anales de la Cátedra Francisco Suárez, Granada, n. ${ }^{\circ}$ 25, 1985, págs. 203-224.

El artículo se estructura en cuatro apartados. En el primero (Observación preliminar) el autor resalta el hecho de que no se puede hablar de teoría tridimensional del Derecho a partir de la simple constatación de que toda experiencia jurídica implica siempre, de un modo u otro, la correlación de hechos, valores y normas, sino sólo cuando de la citada constatación se infieren consecuencias sistematizadas, lo que puede dar lugar a diferentes orientaciones en un amplio espectro de posiciones. El artículo se dedicará a la clarificación de la posición del autor. En el segundo apartado (Sentido de las palabras, hecho, valor y norma en el ámbito del historicismo axiológico), tras exponer biográficamente la génesis de la teoría tridimensional, procede a la definición de valor (es una intencionalidad historicamente objetivada en el proceso de la cultura que implica siempre el sentido vectorial de una acción posible); hecho (es tanto lo que acontece independientemente de la iniciativa humana, pero adquiere significado inter homines como lo que es hecho intencionalmente y se refiere ad alios); y norma (toda norma jurídica señala una toma de postura ante los hechos en una función tensional de valores). En el tercer apartado (Dialecticidad de hecho, valor y norma. Dialéctica de complementariedad y «Lebenswelt») el autor cifra como momento decisivo de sus investigaciones el «descubrimiento... de la naturaleza dialéctica o dinámica de elementos hasta entonces analizados separadamente (dando lugar a dominios separados de investigaciones, como la axiología jurídica, la sociología jurídica y la dogmática jurídico-normativa) o bien de manera estática sin reconocer su radical historicidad». Desde ese momento hecho, valor y norma se consideran menos como elementos y más como momentos de un proceso, lo cual venía a confirmar que, «siendo el Derecho una

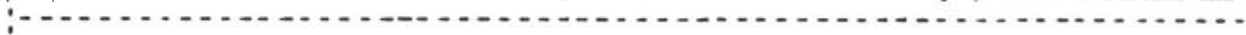

\section{REBUFFA, Giorgio,}

El análisis económico del derecho. (Trad. de Mariano Maresca).

Anales de la Cátedra Francisco Suárez, Granada, n. ${ }^{\circ} 25$, 1985, págs. 161-187.

Este trabajo se estructura en tres apartados. En el primero (Ciencia económica y ciencia jurídica) el autor se centra en la idea de que la ciencia económica y la ciencia jurídica se han desarrollado por caminos diferentes con la idea común de que lo que es relevante para los economistas no lo es para los juristas, y viceversa. Ello fundamentalmente, se ha debido a que para la ciencia económica el modelo distributivo (y, por tanto, también las decisiones normativas que permiten implantar un determinado esquema distributivo) es considerado «un dato», y a que la ciencia jurídica ha fijado sus confines en el interior de las normas positivas, negando cualquier relevancia a la indagacion sobre los efectos distributivos de las decisiones normativas. A todo esto, según el autor, subyace un postulado común: «la afirmación de que los equilibrios distributivos no están influidos por las prescripciones jurídicas, sino autónomamente determinados por la miríada de decisiones microeconómicas que, en su conjunto, se llaman 'mercado'» (con una doble connotación, descriptiva y prescriptiva). Pues bien, para el amor, el principal carácter del conjunto de doctrinas reunidas bajo la denominación de análisis económico del Derecho radica en el intento de superación de lo anterior estudiando los efectos económicos de las decisionesjurídicas.

En el apartado segundo (La crítica de Coase y sus consecuencias), el autor se detiene en la exposición de las tesis de Ronald Coase, cuyo teorema, que pretende identificar el modelo más eficiente (es decir, el menos productivo de costes y efectos externos) de asignación de derechos, supondrá la sustancia de lo que es en la actualidad el análisis económico del Derecho. Y, por último, en el apartado tercero (Tendencias del análisis económico 
dimensión de la vida humana, compartía, o mejor, expresaba la dialecticidad del hombre, entendido como el único ente que originariamente es y debe ser, o en otras palabras, como ente cuyo ser es su debe ser». Y, por último, en el apartado cuarto (La triple estructura de la experiencia jurídica. Los modelos jurídicos) tras establecer algunos puntos «sobre la naturaleza estructural del universo jurídico», el autor se detiene en tres especies de estructuraciones jurídicas: las estructuras del Derecho Natural, las estructuras del ordenamiento jurídicopositivo y las estructuras jurídico-hermenéuticas.

(J. A. R.)

del Derecho), el autor se ocupa de los desarrollos de las indicaciones de Coase por parte de Richard Posner y Guido Calabresi, así como de la recepción de las teorías de estos últimos por parte de algunos juristas europeos.

(J. A. R.) 
RIVERO, Jean.

Sobre lo evolución contemporánea de la teoría de los derechos del hombre.

Anales de la Cátedra Francisco Suárez, Granada, n.o 25, 1985, págs. 189-202.

El artículo se centra en la exposición de dos movimientos opuestos en relación con la teoría de los derechos del hombre en los últimos veinte anos.

«El primero es pesimista. Constata que, a partir de una ampliación -a primera vista positiva- del campo de aplicación del concepto, sus fundamentos doctrinales se han erosionado hasta el punto que hoy resulta difícil precisar su definición. Esta erosión culmina con los esfuerzos llevados a cabo en el seno de instancias internacionales para promover 'nuevos derechos del hombre' que completan el cuestionario de la doctrina inicial.

Pero a la inversa, y paralelamente, los últimos veinte años han contemplado el retorno espectacular de una importante corriente de pensamiento relativa a los derechos del hombre, la de la Iglesia católica. A las condenas de que habían sido objeto a lo largo de todo el siglo XIX, ha sucedido, desde 1963 y tras una lenta evolución, una adhesión explícita que ha dado lugar a una profundización y renovación de las bases del concepto».

(J. A. R.)

\section{ROBLES, Gregorio.}

Tres tipos de reglas en el Derecho.

Cuadernos de la Facultad de Derecho, Palma de Mallorca, n. ${ }^{\circ}$ 11, 1985, págs. 113-128.

El Derecho, desde un punto de vista formal o lógico-lingüístico, es un sistema de reglas («llamamos regla a una expresión linguística dirigida, por su carácter vectorial, a orientar o dirigir -directa o indirectamentela acción» (pág. 116)) de tres tipos: reglas ónticas, reglas técnico-convencionales o procedimentales y reglas deónticas o normas. Las primeras son aquéllas que crean los elementos ónticos del sistema y see expresan, o son expresables, mediante el verbo ser, que en la regla óntica no tiene un carácter descriptivo ni calificativo (razón por la cual la regla óntica no es equiparable a la definición ni al acto de poner nombre a las cosas) pues no se refiere a ninguna realidad preexistente, sino que es la misma regla óntica la que crea la realidad. El segundo tipo de reglas, las técnico-convencionales o procedimentales, son las que establecen cómo tiene que operar el sujeto para que su acción sea jurídica, señalando los requisitos necesarios para que el conjunto de movimientos realizados por el agente pueda ser calificado de acción perteneciente al ámbito. Lingüísticamente se expresan, o son expresables, mediante el verbo tener que, que, a diferencia del deber, no acepta la idea de infracción, pues quien no realiza los movimientos exigidos por la regla procedimental no infringe nada, dado que su acción no pertenece al ámbito óntico-práctico que es el Derecho. Por último, aparecen en el Derecho el tercer tipo de reglas, las deónticas o normas, que son las que expresan un deber y que, a su vez, son de tres clases: a) normas de conducta, que son las que expresan un deber dirigido a determinados sujetos de Derecho, que no tienen la cualidad de órganos, sino la de súbditos o ciudadanos: b) normas de decisión, que no van dirigidas a los ciudadanos sino a un organo al que se le impone el deber de decidir; y c) normas de ejecución que son las

RODILLA, Miguel Ángel.

Buchanan, Nozick, Rawls: Variaciones sobre el estado de naturaleza.

Anuario de Filosofía del Derecho, Madrid, n.ํ2, 1985, págs. 229-284.

En este extenso artículo, el autor, tras situar el contexto del renacimiento del contractualismo en la «rehabilitación de la filosofía práctica», la crisis del «Estado del bienestar», la crítica del utilitarismo.., expone las tres direcciones en las que en la actualidad se desarrolla el enfoque contractualista que, en su opinión, suponen tres respuestas diferentes a la situación que ha provocado el referido renacimiento: Buchanan representa un intento de restauración del viejo liberalismo de «ley y orden» frente a un supuesto estado de erosion de la estructura de los derechos individuales al que denomina «la anarquía constitucional de los años 70»; Nozick supone un intento de radicalizar esa nueva versión del liberalismo de laissez-faire para el que en Norteamérica se reserva el rótulo de libertarismo: y Rawls, en fin, supone un intento de reformular y proporcionar una nueva base a los ideales del pensamiento liberal-democrático.

Ahora bien, el grueso del artículo consiste en un análisis no del contenido del contrato y de sus implicaciones político-prácticas en cada una de estas teorías, sino del punto de partida de las mismas: de la noción de estado de naturaleza. La razón de ello, según nos dice el autor, radica en que las teorías contractualistas -y especialmente las actuales que recurren a un instrumental conceptual fuertemente formalizado- tienden a presentarse como teorías axiomático-deductivas, lo cual supone que «la carga de la prueba de la aceptabilidad de las conclusiones se desplaza decisivamente a la plausibilidad de las premisas». 
que expresan el deber del órgano de ejecución y cuyo contenido es el cumplimiento de lo ordenado por la norma de decisión.

(J. A. R.) 
RODRÍGUEZ-ARIASBUSTAMANTE,Lino.

Teoría de la Institución.

Persona y Derecho, Pamplona, n. ${ }^{\circ}$ 12, 1985, págs. 189-241.

Este artículo es un análisis de lo que se conoce como concepción institucional del Derecho en sus dos modelos: a) el institucionalismo francés de Hauriou, Renard y Delos; b) el institucionalismo italiano de S. Romano. El autor realiza un estudio de los precedentes sociológicos de la doctrina institucional: Durkheim, Duguit y Gurvitch, poniendo así de relieve cómo el concepto de institución, lejos de ser un patrimonio exclusivo de los juristas, constituye un campo de trabajo de diversas ciencias sociales. En torno al análisis de la institución yen relación con él, convergen varias disciplinas hoy íntimamente vinculadas: Sociología, Lingüística, Derecho, Ciencia Política, etc.

Por lo que al terreno estrictamente jurídico se refiere, el autor examina el institucionalismo francés, en particular la teoría de M. Hauriou -sin que falten referencias a Renard y Delos-, desarrollada en sus obras de Derecho Administrativo. Para Hauriou, la institución es «una idea de obra o de empresa que se realiza y dura jurídicamente en un medio social; para la realización de esta idea se organiza un poder que procura organos; por otra parte, entre los miembros del grupo social interesado en la realización de la idea, tienen lugar manifestaciones de comunión dirigidas por los órganos y regulados por un procedimiento». Aparece así la institución como una entidad con vida propia dentro de la sociedad, distinguiéndose a la vez de los miembros que la componen. El autor analiza a continuación la concepción institucional del Derecho desarrollada en Italia por S. Romano. Tras poner de relieve cómo esta concepción está emparentada con la teoría organicista de Otto von Gierke y, en último término, con el historicismo de Savigny, pasa a estudiar la teoría de S. Romano y sus consecuencias

\section{RODRÍGUEZ PANIAGUA, Jose M. ${ }^{\mathrm{a}}$.}

Lecciones de Derecho Natural como Introducción al Derecho.

Ed. Universidad Complutense, Madrid, 1985 (segunda edición), 213 págs.

Esta edición reproduce la primera de 1983 (ver reseña en el n. ${ }^{\circ} 2$ de DOXA) salvo algunas correcciones de estilo y el agregado de un apéndice titulado El artículo 10.1 de la Constitución Española y la fundamentación ética de los derechos humanos.

ROJO SANZ, Jose M. ${ }^{\text {a }}$

Monopolización del poder, objeción de conciencia y consecución de la paz.

Anuario de Filosofía del Derecho, Madrid, n. ${ }^{\circ}$ 2, 1985, págs. 97-106.

El tema central de este artículo es el del hombre frente a los abusos del Estado, en relación con la paz social e internacional.

Respecto a la paz social se entiende que uno de los principales obstáculos era la concepción weberiana del Estado como monopolizador de la violencia legítima, por lo que la crítica actual del Estado habría de situarse en lo aventurado de dicha atribución, frente a posibles abusos estatales. Desde aquel punto de vista, el derecho quedaría reducido al derecho estatal, haciendo posible, incluso, la negación de la resistencia al mismo, por lo que se hace necesario recuperar la relación entre moral y derecho. En efecto, si la moral no se acepta como fundamento genérico de la obediencia de las normas, entonces todo se reduce al éxito o fracaso en la obtención del poder coactivo y en las posibilidades de la más o menos estricta aplicación de éste.

Aquí aparece la objeción de conciencia como posible fórmula de superación de esta situación. Así, la objeción de conciencia trataría de instaurar un orden social no codificable absolutamente. Al oponerse ala sacralización de la ley, a la obediencia como virtud absoluta y a la divinización del Estado, el objetor niega en definitiva, la razón de Estado.

En el plano de la paz internacional, la existencia de bloques, la dependencia de la economía de la industria armamentista y la miseria de muchos pueblos, se configurarían como los principales obstáculos para la paz. Por tanto, se ven como necesario la superación de las vías actuales, pasando por la limitación o supresión del armamentismo, por una nueva redistribución de rentas y jornadas de trabajo, así como el logro de la propia 
más importantes: el pluralismo jurídico y, por tanto, la negación del monopolio estatal en la producción de normas. El autor, siguiendo a A. Tarantino, sintetiza la concepción de S. Romano en los siguientes puntos: a) en el campo extrajurídico, las instituciones se nos presentan como entes sociales de hecho, caracterizados por tener organización, autonomía y estructura propia; b) existen entes infraestatales, como la familia, que difícilmente pueden considerarse como personas jurídicas; c) hay que crear un concepto jurídico más amplio que el de persona jurídica, que comprenda los entes jurídicos autónomos; d) opera una transferencia del concepto de institución del campo extrajurídico al campo jurídico, afirmándose que todo ente jurídico autónomo es una institución; e) establece que el Derecho es organización, independientemente de lo que organiza, es decir, que «distingue el Derecho del hecho organizado, considerando la organización como forma interna, como estructura de la institución, sosteniendo la equivalencia de los conceptos de institución y ordenamiento jurídico, con lo cual se obtiene una perfecta identidad entre sociedad y Derecho».

Recoge finalmente el autor un conjunto de alegatos, unos críticos y otros defensivos, de la teoría de la institución y compara la concepción de S. Romano con las de Kelsen, Duguit y Hauriou.

(F. L. R.)

autonomía económica y política de los pueblos. En definitiva, suprimir la actual economía militarista exige transformar la sociedad actual en una sociedad no militarizada en lo económico, que prestase una mayor atención a los problemas sociales a nivel mundial. 


\section{ROMERO MORENO, Jose M. ${ }^{\mathrm{a}}$}

\section{El ideal de la paz perpetua en Kant.}

Anuario de Filosofía del Derecho, Madrid, n. ${ }^{\circ}$ 2, 1985, págs. 207-216.

Ante la actual situación internacional, que podría ser un «interregno entre dos guerras», cobran especial interés las tesis sobre la paz perpetua que Kant plantea, principalmente, en dos de sus obras: La paz perpetua y $\mathrm{La}$ Metafísica de las costumbres. Doctrina del Derecho.

Para alcanzar una estable y verdadera paz, destaca Kant varias condiciones, ordenadas en dos niveles según sean requisitos para evitar la guerra o para que la paz sea definitiva. Así, en el primer nivel es necesario «no formalizar ningún tratado particular de paz en el que se mantenga la menor reserva de pretexto para una guerra futura»; prohibir la adquisición por vía patrimonial de un Estado por otro, los ejercitos permanentes, la asunción de deuda exterior destinada a sostener una política exterior agresiva, la intervención o intromisión de un Estado en los asuntos internos de los demás Estados; y evitar aquellos actos que puedan cometerse en tiempos de guerra «que hagan imposible la confianza recíproca como garantía de la paz futura». Y para que la paz se mantenga definitivamente -segundo nivel- se requiere: que todos los Estados tengan una forma política basada en la democracia, que el Derecho Internacional se funde sobre una federación de Estados libres y que se haga real la existencia de «un derecho de ciudadanía universal, con la protección ilimitada de los derechos de entrada y salida, así como el de permanencia de cualquier ciudadano en cualquier parte del mundo». Como puede apreciarse, las relaciones de coordinación y jerarquía de estas propuestas «convierten a esta doctrina en una verdadera estrategia».

Pero «el concepto de paz perpetua, como idea trascendental, no tiene un uso constitutivo. Sólo lo sería en el

\section{RUIZ MANERO, Juan.}

Consenso y rendimiento como criterios de evaluación en la dogmática jurídica. (En tomo a algunos trabajos de A. Aarnio).

Doxa, Alicante, n. ${ }^{\circ}$ 2, 1985, págs. 209-222.

Tras explicar algunas características del modo de hacer filosofía del Derechapor parte de Aarnio (fundamentalmente su proximidad a problemas efectivamente planteados en la dogmática jurídica), Ruiz Manero examina la tesis de Aarnio según la cual el criterio de justificación de construcciones dogmático-jurídicas y de decidibilidad entre construcciones dogmáticas contrapuestas se halla en el consenso de la comunidad jurídica.

La cuestión planteada es: ¿con arreglo a qué criterios puede considerarse que una determinada aseveración normativa -enunciado interpretativo, el más frecuente en la dogmática jurídica- está más justificada que otra aseveración alternativa? Tras deducir de aparentes inconsistencias entre fragmentos de Aarnio que la relación entre el enunciado interpretativo (u opción interpretativa) y sus premisas es deductiva aveces y de mera plausibilidad otras, se llega al problema de justificar estos conjuntos de premisas. Aquí introduce Aamio el consenso, pero no el basado en la aceptación efectiva, sino en la aceptabilidad racional de la interpretación.

Sin embargo, observa Ruiz Manero que en otros trabajos de Aarnio se sitúa este mismo criterio en el rendimiento de cada una de estas teorías dogmático-jurídicas en competencia, es decir, en su potencia resolutiva

Estos criterios sólo parecen poder articularse -en opinión de Ruiz Manero- considerando el de consenso como principal y el de rendimiento como subordinado, por lo que la atención debe concentrarse en el primero.

Yen él ve el autor del artículo algunos obstáculos importantes, como son la dificultad de considerara la «comunidad jurídica» como el ámbito adecuado para que se genere ese «consenso racional» (por depender de interpreta-

\section{SARMIENTO, Augusto.}

Textos inéditos de la escuela de Salamanca.

Persona y Derecho, Pamplona, n. ${ }^{\circ} 12$, 1985, págs. 243-321.

Este trabajo es la continuación de la edición de una serie de textos inéditos de la «escuela de Salamanca»; concretamente aquí se trata de los textos del tratado De iustitia et iure de Mancio, cuya primera parte fue publicada en el n. ${ }^{\circ} 10$ de esta misma revista. La preparación de los textos ha estado a cargo de Augusto Sarmiento. En esta segunda parte, se publica un estudio sobre un tema clásico dentro del iusnaturalișmo de esa ẹ́poca que, sin embargo, desborda los límites del Derecho natural para conectar con el Derecho canónico, civil e internacional; concretamente, se trata del texto «Del Dominio», que aborda temas que van desde los modos de adquirir el dominio, su traslación y prescripción hasta el estudio de las potestades gubernativas (Parte 5. ${ }^{\mathrm{a}}$, cuestión 1.a).

(F. L. R.) 
caso de que pudiese ser aplicada a los datos de la experiencia sensible... Por otro lado, la razón humana tiene una inclinación natural, irresistible, a superar esas barreras metódicas; $y$, en nuestro caso, a afirmar inequívocamente la necesidad de la paz. Hay, en ambos momentos de la afirmación, manifestación de espacios igualmente «naturales» de la esencia humana. Afirmada esta naturalidad en la propia idea trascendental de la razon, lo que se plantea es el uso posible de la misma. La afirmación de la existencia de tal uso es muy claro en Kant; es el uso hipotético, unificador, problemático, que hemos visto denominar regulativo. En la expresión de Kant tales ideas actúan como foco de atracción y unificación de nuestros esfuerzos. Así ocurre también con las ideas de mundo, alma y Dios.

En otras palabras, esta vez del Filósofo: «ya no se trata de contestar a la pregunta de si es realmente posible la paz perpetua, o de si quizá nos hemos equivocado en nuestro juicio teorético si asumimos que lo es. Por el contrario, debemos actuar simplemente como si ello pudiera ser así (lo cual quizá sea imposible) y volcar nuestros esfuerzos en hacerla realidad y en establecer las leyes y condiciones que parecen más acorde con este propósito (quizá aquellas propias del republicanismo en todos los Estados, individual y colectivamente). Trabajando con este fin, podemos esperar acabar con la desastrosa práctica de la guerra...».

(D. G. L.)

ciones establecidas por vía de autoridad), su imposibilidad en una comunidad jurídica donde no exista un acuerdo en torno a los valores básicos (pues el disenso se situaría más allá de las posibilidades de la discusión racional), y el eventual desfase entre las valoraciones predominantes en esta comunidad jurídica y las predominantes en la sociedad.

(M. J. M. C.) 
SORIANO, Ramón.

El nuevo jurado español.

Ed. Ariel, Barcelona, 1985, 157 págs.

La presente investigación se centra fundamentalmente en dos campos de estudio: primero, examen y valoración de las argumentaciones juradistas y antijuradistas; segundo, análisis de la forma, competencias y funcionamiento que ha de adoptar nuestro futuro jurado conforme al mandato del art. 125 de la Constitución. Ahora bien, el libro, lejos de ser un estudio puramente procesalista, de carácter técnico y científico-jurídico, constituye una aproximación a la problemática del jurado en cuanto que este es el reflejo institucional de una concepción democrática de la interpretación y aplicación del Derecho: «El jurado es, en efecto, la institución equiparable en el seno del Poder Judicial al Parlamento en el ámbito del Legislativo».

En el capítulo segundo el autor repasa las principa, les concepciones de la interpretación y aplicación del Derecho (desde el formalismo jurídico, que parece abso ber la función judicial en el ámbito de la legislación, hasta la libre creación del Derecho, que convierte a los jueces en legisladores); en el tercero, estudia al jurado como punto de convergencia entre la independencia judicial y el control social de la justicia; en el cuarto, trata el problema de la fundamentación de la institución del jurado dando un repaso a los argumentos de las tesis juradistas y antijuradistas; en el quinto, se detiene en el concepto de jurado, distinguiendo entre el jurado histórico y el nuevo jurado o jurado escabinado; $\mathrm{y}$, en el sexto titulado Hacia un nuevo jurado español: el jurado de escabinos, se detiene en las experiencias juradistas europeas (Francia, Italia, República Federal de Alemania y Suiza) y en los precedentes doctrinales y constitucionales para, al final, hacer algunas reflexiones con la mira puesta en la regulación del futuro jurado español.

\section{SORIANO, Ramón.}

\section{La paz y la Constitución española de 1978.}

Anuario de Filosofía del Derecho, Madrid, n. ${ }^{\circ}$ 2, 1985, págs. 133-161.

«La interpretación de la paz como valor jurídico -en palabras del autor- depende de las circunstancias histórico políticas, de la jerarquía axiológica del propio intérprete -ya que la paz es contemplada frecuentemente como un valor formal y consecuentemente secundario en comparación con otros valores materiales y primarios- y de su carácter aséptico o ideológico respecto a su aprovechamiento por las filosofías políticas.

La paz recibe dispares tratamientos doctrinales y jurídico-positivos, pues es un valor de urgencia, de primerísimo orden, cuando falta la convivencia misma de los ciudadanos, pero es relegada a un segundo plano, cuando, por existir, deja el paso a otros valores jurídicos que vienen a ocupar el nivel de urgencia abandonado por la paz ya conquistada. Esto explica que se valore especialmente la necesidad de la paz en las relaciones internacionales, ya que aquí el bellum omnium in omnes del estado de naturaleza hobbesiano es todavía desgraciadamente una realidad que salta a la vista, mientras que en las relaciones internas de los Estados sólidos la paz no comporta esta acuciante premura. Como advierte Harich, uno de los autores mas preocupados por la amenaza de una guerra nuclear, la paz es todavía el valora construir en las relaciones supra-estatales, cuya atención absorbente apenas deja lugar para atender a otros objetivos».

«En nuestra Constitución -continúa el autor- la paz está presente como valor jurídico en las relaciones internacionales y en las relaciones internoestatales de la convivencia ciudadana; pero en ambos aspectos, a mi juicio, la referencia constitucional es excesivamente comedida. No hay un compromiso desarrollado del Estado en pro del mantenimiento de la paz internacional, ya que el mero propósito del preámbulo constitucional en este senti-

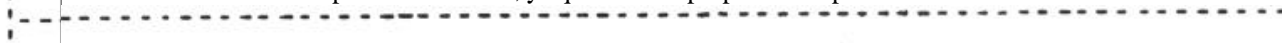

\section{SOSA MORATO, Beatriz Eugenia.}

La noción de derecho en «Los Seis Libros de la Justicia y el Derecho» de Luis de Molina.

Ed. Eunsa, Pamplona, 1985, 414 págs.

El presente volumen recoge un extenso trabajo sobre la noción de Derecho en el jesuita castellano Luis de Molina (1535-1600). La obra se estructura en tres capítulos. En el primero de ellos, Marco histórico-doctrinal, la autora ubica a Molina en su tiempo marcando las circunstancias que repercuten en su obra y esboza «los presupuestos doctrinales que tienen interés en su sistema jurídico». En el capítulo segundo, De la justicia en general y de sus clases, "presenta una visión sinóptica de la justicia y sitúa al Derecho como el objeto propio de la misma». El tercero, El Derecho (I. La noción de derecho y II. La división del derecho), que es el capítulo central de la obra, «tiene por objeto de estudio al Derecho mismo».

La obra además se ve complementada por ocho anexos (1. tabla cronológica de Luis de Molina; 2. relación de los temas estudiados por Molina durante su magisterio en Evora; 3. esquema de concordancias entre el De Iustitia et Iure, su edición castellana y los temas tratados en la obra; 4. cuadros sobre las ediciones del Iustitia et Iure; 5. tabla sobre el proyecto inicial de la obra de Molina y las publicaciones hechas hasta 1600; 6. presentación cronológica de algunos autores pertenecientes a la Escuela española de Derecho natural; 7. tabla cronológica de las obras escritas en los s. XVI y parte del XVII sobre la justicia y el Derecho; 8. tablas de las fuentes que en cada tema utilizó Molina) y una bibliografía. 
Por último, el libro contiene un capítulo final de conclusiones de las que pueden destacarse las siguientes: 1) El art. 125 de la Constitución no tiene un carácter meramente orientativo o programático, ni tampoco, contiene una remisión facultativa a la ley, de modo que sea el legislador quien aprecie la conveniencia o no, en un momento dado, de legalizar el jurado, sino que, muy al contrario, ordena expresamente la elaboración de una ley de jurado, dejando carta blanca sobre los tẹrminos de esta regulación. 2) El futuro juradọ debe adoptar la forma de un jurado de escabinos, que es una institución sólidamente asentada en los ordenamientos jurídicos europeos. 3) El jurado de escabinos, que conjuga la representación popular y la representación técnica, debe primar la representación ciudadana para que ésta no sea un mero complemento sino una realidad, alcanzando el relieve y la eficacia proclamados en la Constitución.

\section{(J. A. R.)}

do no es acompañado de fórmulas de autolimitación de la soberanía nacional, como es el caso de otras constituciones europeas. Por otro lado, la paz como valor interno-estatal no recibe un tratamiento prioritario constitucional, como otros valores jurídicos, pues además de estar ausente del artículo 1.1 de la Constitución -que es donde, a mi parecer, debía haberse incluido-, cuando aparece en el artículo 10,1 ya fuera del título preliminar, se muestra apoyado en unos fundamentos liberal-conservadores que lastran en gran medida su significado y extensión y permiten una interpretación restrictiva».

(A. D. P. y D. G. L.) 
VERNENGO, Roberto-J.

Validez y verdad en la «Teoría de las normas», de Hans Kelsen.

Anales de la Cátedra Francisco Suárez, Granada, n. ${ }^{\circ}$ 25, 1985, págs. 13-28.

El artículo arranca con una breve exposición a propósito de las diversas opiniones vertidas por juristas dogmáticos y filósofos del Derecho sobre la estructura lógica del discurso de la teoría general del Derecho: por un lado, están quienes afirman que la ciencia del Derecho no sería aceptable de no satisfacer un mínimo de logicidad y, por extensión, que el objeto de estudio -las normas- debe estar sujeto acondiciones formales de consistencia y deducibilidad; y, por otro lado, están quienes niegan el carácter lógico de la ciencia dogmática y que, además, sostienen que el Derecho mismo no tiene una estructura lógica «que autorice a implantar exigencias de consistencia y deducibilidad». La cuestión crucial -para el autor- reside en precisar cuáles son las propiedades semánticas características que pueden atribuirse a las normas. En este sentido, constata que la propiedad característica que ha sido generalmente propuesta en el discurso normativo, como afín ala verdad en el discurso declarativo, es la validez: así como las proposiciones pueden ser verdaderas o no, las normas (al menos las jurí dicas) pueden ser validas o no. A partir de este planteamiento, el autor se adentra en el análisis de algunas de la conclusiones que Kelsen formuló al respecto en su obra póstuma Allgemeine Theorie der Normen.

Del análisis del amor pueden extraerse, al menos, las siguientes conclusiones: A) En Kelsen el concepto de «validez»tienediversossentidos: 1) validez en relación a un enunciado normativo bien formado (acto de voluntad destinado a producir un cambio en la conducta ajena con una suficiente determinación de sus ámbitos de aplicación); 2) validez en relación a un deber de observancia de las normas; y 3) validez en relación a $-$ aquellas normas derivadas lógicamente según reglas de inferencia admitidas incluso en los lenguajes natura-

\section{WALTER, Robert.}

Las normas jurídicas. (Trad. de Manuel Atienza y Heike Cordes).

Doxa, Alicante, n. ${ }^{\circ} 2$, 1985, págs. 107-115.

Un aporte singular en la elaboración de la tipología de las normas jurídicas lo constituye este trabajo de R. Walter a partir de la piedra angular colocada por H. Kelsen en su Teoría Pura del Derecho, y aprovechando materiales de la Teoría General de las Normas.

Sin olvidar que las normas de mandato están en el centro del ordenamiento, R. Walter considera que también hay otras, en conexión con ellas, que no prescriben una sanción, sino que autorizan la producción de normas de comportamiento dotadas de obligación, o autorizan la aplicación de estas mismas, e incluso que pueden autorizar la producción de las propias normas de autorización citadas.

Por otra parte, si todas las normas jurídicas son normas de obligación y/o de autorización (pues no parece necesario aceptar la existencia de las denominadas «de permisión», inmersas en una u otra categoría) ¿cómo encuadrar las que, por ejemplo, derogan la obligación mandada? La conclusión es evidente: hay normas con función propia, las de derogación, no reducibles a ningún otro tipo.

Todas estas normas, su graduación, las cuestiones de su correlación, y los conflictos que se pueden plantear entre ellas y su posible solución, junto con una breve disgresión sobre normas y prescripciones jurídicas, ponen fin al trabajo, quedando patente para el autor la importancia y necesidad de alumbrar esta nueva manera de ver el «deber», y, con ello, comprender mejor los diversos tipos de normas. 
les. B) Kelsen rechaza que puedan caracterizarse como verdaderas las normas válidas en cualquiera de los tres sentidos referidos. C) Esta no aceptación de la calificación de verdaderas alas normas válidas en el tercer sentido de validez se debe, tal vez, a que Kelsen opera con una concepción de la verdad como correspondencia, que deja «fuera de juego la verdad como coherencia con las reglas sintácticas de un lenguaje y la verdad formal de ciertas relaciones de derivación».

(J. A. R.) 


\section{Presentación}

Los deberes positivos

Ernesto Garzón Valdés

Los deberes positivos generales y su fundamentación

Juan Carlos Bayón

Los deberes positivos generales y la determinación de sus límites (Observaciones

al artículo de Ernesto Garzón Valdés)

Francisco Laporta

Algunos problemas de los deberes positivos generales (Observaciones a un articulo de Ernesto Garzón Valdés)

Ernesto Garzón Valdés

Algunos comentarios críticos a las críticas de Juan Carlos Bayón y Francisco Laporta

James S. Fishkin

Las fronteras de la obligación

Las ficciones en el Derecho

Aulis Aarnio

Persona jurídica, ¿una ficción?

Enrique E. Marí

Racionalidad e imaginario social en el discurso del orde

Manuel Calvo García

La voluntad del legislador: Genealogía de una ficci/ ón hermenéutica

José Juan Moreso Mateos

Las ficciones en Jeremy Bentham. El método de la paráfrasis

Rafael Hernández Marín

Ficciones juridicas

Claudio Souto

La ficción de la autosuficiencia en

\section{Artículos}

Javier Muguerza

Razón, utopía y disuto

Juan Ruiz Manero

Sobre la crítica de

Roberto J. Ver

Sobre algunos

Marshall Cohen

Escepti cismo moral en las relaciones internacionales

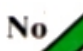

tas

$\mathrm{Ma}$

nuel Jiménez Redondo

Preci siones sobre Rawls

Roberto

J. Vernengo

Ciencia jur ídica o técnica política: ¿Es posible una ciencia del Derecho?

Manuel Atienza

Sobre la Jurispru

Roberto J. Vernengo

Réplica a la respuesta de

dencia como técnica social. Respuesta a Roberto J. Vernengo

Entrevista

Manuel Atienza y Juan Ruiz Ma

M. Atienza

Entrevista con Felipe González Vicén

Bibliografía

Josep Aguiló Regla y Francisco López Ruiz (coords)

La filosofía del Derecho en España (1985) 